\title{
PANAM NAGAR, THE ANCIENT CITY OF BENGAL: IN SEARCH OF CONTINUITY IN TRADITION
}

\author{
By \\ Sadia Akhter \\ A Thesis submitted to the \\ Faculty of Graduate Studies and Research \\ In partial fulfillment of \\ the requirements for the degree of \\ Masters of Architecture \\ School of Architecture \\ Carleton University \\ Ottawa, Ontario
}

(C) 2004, Sadia Akhter 
Library and

Archives Canada

Published Heritage

Branch

395 Wellington Street Ottawa ON K1A ON4

Canada
Bibliothèque et

Archives Canada

Direction du

Patrimoine de l'édition

395 , rue Wellington

Ottawa ON K1A 0N4

Canada
NOTICE:

The author has granted a nonexclusive license allowing Library and Archives Canada to reproduce, publish, archive, preserve, conserve, communicate to the public by telecommunication or on the Internet, loan, distribute and sell theses worldwide, for commercial or noncommercial purposes, in microform, paper, electronic and/or any other formats.

The author retains copyright ownership and moral rights in this thesis. Neither the thesis nor substantial extracts from it may be printed or otherwise reproduced without the author's permission.
AVIS:

L'auteur a accordé une licence non exclusive permettant à la Bibliothèque et Archives Canada de reproduire, publier, archiver, sauvegarder, conserver, transmettre au public par télécommunication ou par l'Internet, prêter, distribuer et vendre des thèses partout dans le monde, à des fins commerciales ou autres, sur support microforme, papier, électronique et/ou autres formats.

L'auteur conserve la propriété du droit d'auteur et des droits moraux qui protège cette thèse. $\mathrm{Ni}$ la thèse ni des extraits substantiels de celle-ci ne doivent être imprimés ou autrement reproduits sans son autorisation.
In compliance with the Canadian

Privacy Act some supporting forms may have been removed from this thesis.

While these forms may be included in the document page count, their removal does not represent any loss of content from the thesis.
Conformément à la loi canadienne sur la protection de la vie privée, quelques formulaires secondaires ont été enlevés de cette thèse.

Bien que ces formulaires aient inclus dans la pagination, il n'y aura aucun contenu manquant.

\section{Canada}




\title{
PANAM NAGAR, THE ANCIENT CITY OF BENGAL: IN SEARCH OF CONTINUITY IN TRADITION
}

\author{
By
}

Sadia Akhter

\author{
A Thesis submitted to the \\ Faculty of Graduate Studies and Research \\ In partial fulfillment of \\ the requirements for the degree of \\ Masters of Architecture
}
School of Architecture
Carleton University
Ottawa, Ontario

(C) 2004, Sadia Akhter 


\section{Abstract}

Bangladesh is a country considerably rich in archaeological wealth. One of the extremely potential sites in Bangladesh is the 'Panam City' or 'Panam Nagar' in Sonargaon, near Dhaka. Unfortunately most of the structures at Panam have reached a state of decay. The government as well as the people are ignoring them and are not taking any steps to save the relics. If we continue to neglect and abuse these historical structures our next generation will not be able to witness their glorious past.

Sonargaon is not only a place of historical importance, it signifies our heritage and culture. It has become imperative that the area be conserved properly as the first attempt to bridge the discontinuity in history.

This thesis proposes that the ancient 'Panam Nagar' should be given life once again by transforming it into a modern and active city through adaptive re-use of some of the buildings and regeneration of the business and trade activities that flourished in Sonargaon. 


\section{Acknowledgement}

For this thesis, I owe a debt of gratitude to my thesis supervisor Prof. Stephen Fai. His criticism and guidance have helped me to proceed in the right direction. I am indebted to Prof. Dr. A K M Shahnawaz of Archaeology Dept. in Jahangir Nagar University for his enormous support and guidance. I am also grateful to Prof. Greg Adonian of Carleton University and Prof. Dr. Syed of Asia Pacific University for helping me with resources. Thanks to Mr. Mosleh Uddin at Bangladesh Archaeological Department for providing me with valuable resources. And many thanks to all my friends ( Arafat, Rizve, Mamun, Tanvir and Wahid) and specially my parents for their inspiration and support during the hard days of my research.

I dedicate this research to my mother who has always been the source of my courage and confidence. 


\section{Contents}

Chapter 1: Introduction

1.1 Overview of the site

1.2 Geographical information

1.3Objective of the research

1.4 Importance of the research

1.5 Scope and limitation of the research

Chapter 2: Methodology

$\operatorname{Pg} 18$

2.1 Approach

2.2 Exploiting primary sources

2.2.1 Physical survey of existing condition

2.2.2 Survey of similar situations

2.2.3 Socio-economic survey

2.2.4 Questionnaire survey

2.3 Study of secondary sources

2.3.1 Accounts of travelers

2.3.2 Books, articles, reports

2.4 Data analysis

2.5 Result of the survey and study

Chapter 3: Historical Sonargaon

$\operatorname{Pg} 29$

3.1 Historical background

3.2 Society

3.3 Culture

Chapter 4: Present condition

$\operatorname{Pg} 50$

4.1 Present condition at Panam

4.2 Architectural style

4.2.1 Patterns

4.2.2 Architectural ambience

4.2.3 Material and construction

4.2.4 Formal order of buildings

4.2.5 Building typology

4.3 Other Monuments at Sonargaon 
Chapter 5: Problems and Proposals

$\operatorname{Pg} 83$

5.1 Recommendations

5.2 Phase One: Policy Level

5.2.1 Demarcation of boundary

5.2.2 Identification and listing of monuments

5.2.3 Classification of listed monuments

5.2.4 Justification for conservation

5.2.5 Rules and regulation

5.2.6 Participation of local people

5.3 Phase Two: Planning Level

5.3.1 Preparation of a master plan

5.3.2 Cause and probable solution for deterioration

5.4 Phase Three: Implementation Level

Chapter 6: Case studies

$\operatorname{Pg} 110$

6.1 Reuse of Nineteenth Century Row houses in Istanbul

6.2 Shakhari Potti, a unique old city settlement, Dhaka

6.3 Comprehensive analysis of 5 architectural conservation projects.

Chapter 7: Conclusion

$\operatorname{Pg} 141$

\section{Bibliography}

Appendix 


\section{Chapter 1: Introduction}

\subsection{Overview of the site}

At the beginning of the $12^{\text {th }}$ century, Sonargaon came into prominence as the administrative center in the early medieval period; when Vikrampur, the ancient capital of Banga, lost its importance. With the establishment of Muslim rule in this area during the last years of the 13th century, Sonargaon became the capital of Bang and was well known. It continued to enjoy this prominence, with various vicissitudes, until the occupation of this area by the Mughals in the early part of the 17th century, when the capital was shifted to Dhaka. Though shorn off from the prestige of a capital, Sonargaon continued its prominence until the end of the 18th century. With the decay of the once flourishing cotton manufactures, for which the tract of land between the Sitalakhya and the Meghna was famous, Sonargaon fell into oblivion only to be revived by the emergence of the town of Panam, an abode of Hindu merchants, who have set up their residences on the older site during the 19 th century and 20 th century. ${ }^{1}$

Sonargaon's archaeological remains cover a wide period of time. While hardly anything remains of the pre-Muslim period, remnants of the Muslim period are strewn over a vast area and, in part, grew into the existing site of the Colonial period. 
Sonargaon's pre-Muslim existence is borne by its ancient name of Suvarnagrama, from which it is apparent that the Muslim version of the name is derived. ${ }^{2}$ The fact that this tract of land, which came to be designated as Sonargaon, was important in the ancient period is borne out by the fact that the traditional Hindu holy bathing places of Langalbandh and Panchami Ghat are situated on the western bank of the Brahmaputra that runs through this tract. These two places are still held sacred by Hindus and the bathing festival in the month of Chaitra on the 8th day of the bright half of the moon is a great occasion among Hindus in Bangladesh.

The medieval capital of eastern Bengal survives only in the name of Sonargaon, which is at present the name of a thana in the district of Narayanganj. The Dhaka-Chittagong highway cuts through this thana in a south-easterly fashion, traversing the southern part of the thana, and the name of Sonargaon survives in the name of a Union situated between Baidyer Bazar Union on the north and Pirijpur Union to the south; the river Meghna flows by the western side of these three Unions. The adjacent thana of Bandar to the west, lying between the Brahmaputra and the Sitalakhya, may have had inseparable links with the Sonargaon area, as is evidenced by archaeological remains.

So, the site of Sonargaon could be thought as a vast tract of land lying between the Sitalakhya, on the west, and the Meghna, on the east, about $27 \mathrm{~km}$ to the 
south-east of the present metropolis of Dhaka. It is also difficult to fix the northern limit of the territory of Sonargaon. For instance, N. K. Bhattasali suggested that "a line drawn eastwards from Dewra on the Lakhya to meet the Meghna would be the approximate boundary between Sonargaon and Maheswardi." ${ }^{3}$ Bhattasali was probably thinking about the Mughal Pargana of Sonargaon, the total area of which he estimated to be about 24 square miles. It is, however, likely that the course of the Brahmaputra running from west to east, before taking a southerly direction near Muazzampur (Mohjampur in the Jampur union) in the northern part of the thana, may have formed a natural northern boundary for Sonargaon.

If the northern boundary is uncertain, the southern boundary of Sonargaon is well defined by the confluence of the Sitalakhya, the Dhaleswari and the Meghna, giving a triangular shape to the southern tip of the tract. The advantages of river traffic to all parts of Bengal from this point to the sea by the Meghna gives this tract of land geophysical importance, capitalizing on which the capital city of Sonargaon flourished in the medieval period.

Today, one does not find the remains of the city of Sonargaon in a well defined composition. There one sees the remains of a few medieval buildings, mostly religious, scattered in the region defined above, and now existing with the village names of Aminpur, Panam, Dulalpur, Goaldi, Mograpara, Nagar Sadipur, Sachilapur and Bhagalpur etc. The remains are mostly in the southern part of the 
Sonargaon and Bandar thanas in the district of Narayanganj. The whole area, over which the remains are scattered, has a well-formed land mass with heavy human habitation. The Brahmaputra river, at present a rather thin flow, runs in a southerly direction forming the boundary between the Sonargaon thana and the Bandar thana which lies to its west. The Sitalakhya river flows almost parallel to the Brahmaputra stream, a few miles to the west, forming the dividing line between the Bandar thana and Narayanganj, which lies on the western bank of the Sitalakhya.

The writings of foreign travelers to Sonargaon from Ibn Batuta (1346) to Ralph Fitch (1586) bear testimony to the fortunes of this place. Although it is difficult to ascertain the exact location and boundary of the area from their description, the Chinese accounts of Mahuan (early $18^{\text {th }}$ century) and Fei Sin (1415) have more definite details. Mahuan speaks of his journey on a small boat from Chittagong for about 500 li (Chinese unit of distance) to reach "So-na-eul-kiang" (Sonargaon). Fei Sin also describes "So-na-eul-kiang" (Sonargaon) as "a walled place with tanks, streets, bazaars". ${ }^{4}$

James Wise in his 'Notes on Sunargaon', published in 1874, records his impression about Sonargaon along with a survey of the extant buildings and a sketch of the history of Sonargaon. He also discusses the changes in the course of the Brahmaputra. He describes the shallow stream of the Brahmaputra very 
similarly to what it is today. ${ }^{5}$

The extant sites of archeological interest in and around Sonargaon may be divided into the following four groups:

a. Northern group: Panam - Goaldi group on the northern side of the Dhaka Chittagong highway. The area includes the Goaldi mosque, the Khashnagar Dighi (pond), Bari Majlis, Baliar Dighi area and Panam Nagar itself.

b. Southern group: Mograpara group covering the area of the present Mograpara union on the southern side of the Dhaka - Chittagong highway. In this group are included the Damdama (fort), Dargabari complex, the tomb of Sultan Ghyasuddin Azam Shah and the Panch Pir Dargah.

c. Bandar group: Sites in the Bandar thana include Qadam Rasul complex, Bandar Shahi mosque and the Sonakanda Fort.

d. Periphery group: sites in the outskirts of the above three groups.

\subsection{Geographical information}

In the $15^{\text {th }}, 16^{\text {th }}$ and $17^{\text {th }}$ century, Sonargaon was a capital and a magnificent town in Bengal. But, during the $18^{\text {th }}$ century, when the capital was shifted to Dhaka, Sonargaon lost its prominence and was eventually forgotten. In course of time, descendants of the merchants who originally lived in Sonargaon returned to this area and built a new town, the Panam Nagar, over the ruins of the once 
thriving capital. The area we generally called 'Panam' in fact consists of Panam Nagar, Goaldi, Barasarder Bari, Dulalpur and Mograpara under the Sonargaon District.

Sonargaon is at present the name of a 'Thana' in the district of Narayanganj. Panam Nagar is a small area compared to the entirety of Sonargaon and is situated off to the north-east of the ancient capital city.

Dr. B. Hamilton, who visited this region in 1820 writes, "This is reputed to have been once a large city, ... situated on one of the branches of Brahmaputra, about 13 miles south-east from Dacca, latitude $23^{\circ} 39^{\prime} \mathrm{N}$., longitude $90^{\circ} 43^{\prime} \mathrm{E} . ”$

Panam Nagar is a unique township stretched along a single road $5 \mathrm{~m}$ wide in average and $600 \mathrm{~m}$ in length. Fifty houses in brick, in a dilapidated and disused condition, are arranged on both sides of this road in close proximity. 
SONARGAON

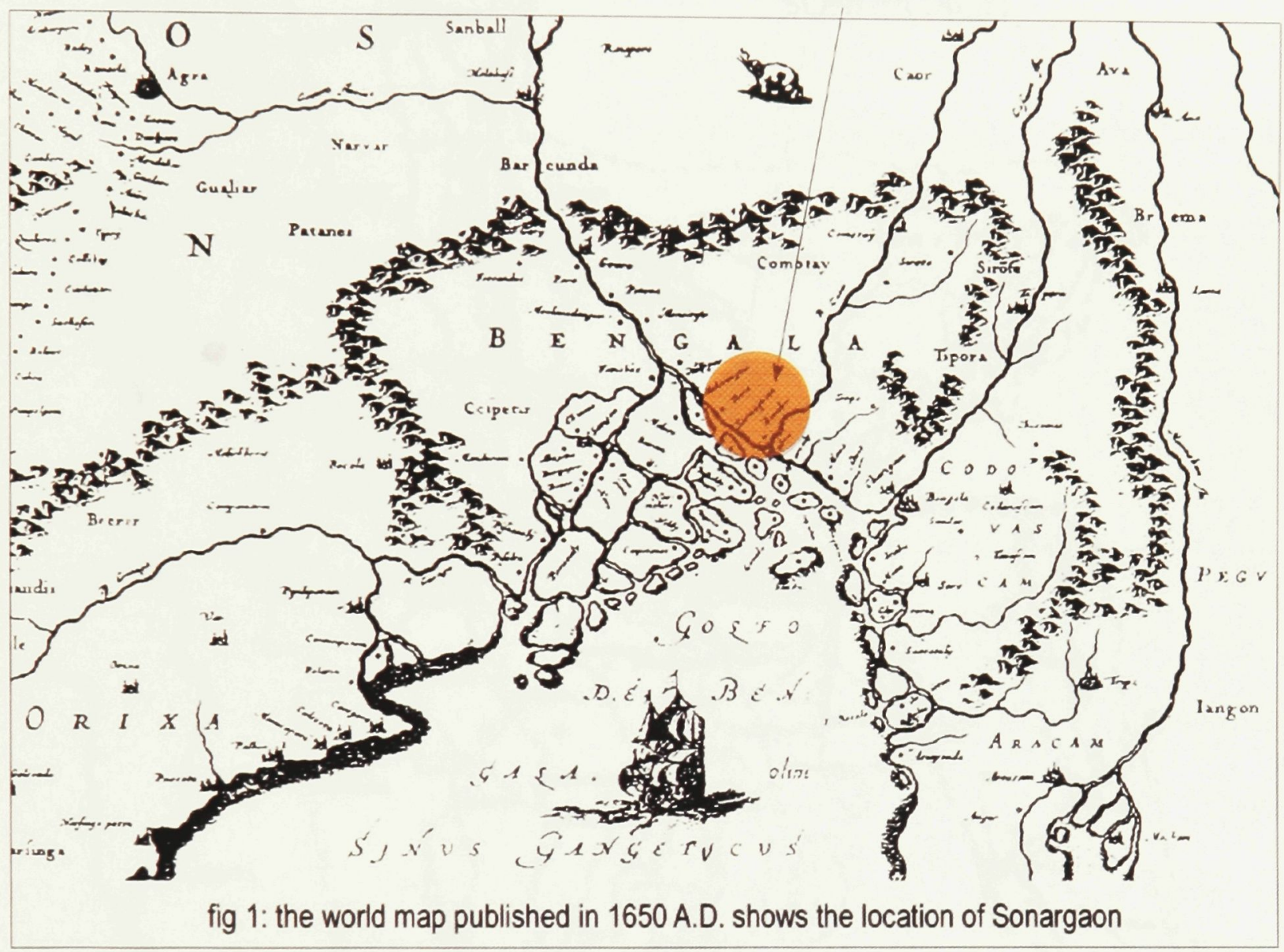

Fig 1: The world map published in 1650 A.D. shows the location of Sonargaon. Source: Department of Archaeology, Bangladesh Government 


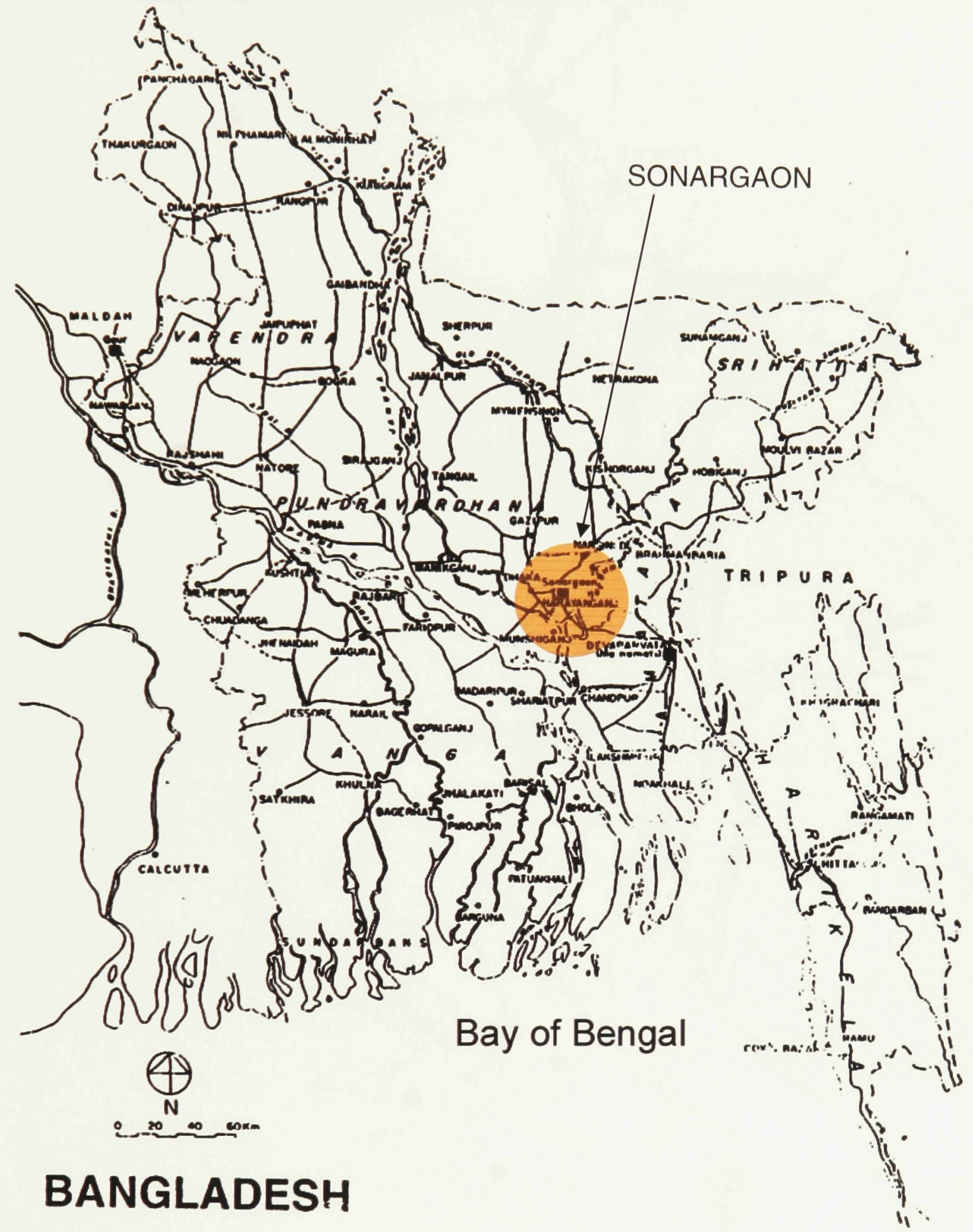

Fig 2: Location of Sonargaon area.

Source: published map of Government of Bangladesh. 


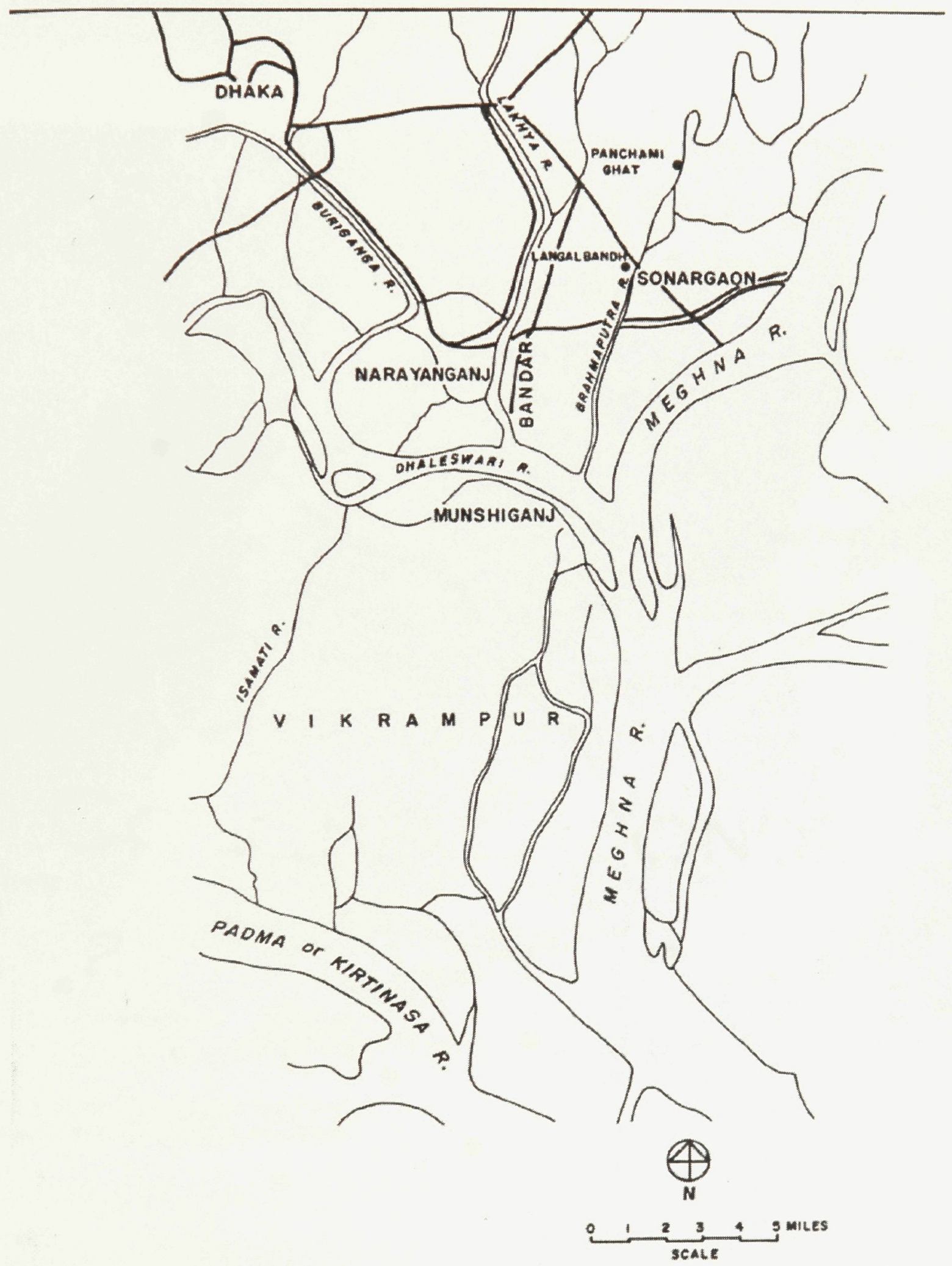

Fig 3: Sonargaon and surrounding area.

Source: Hussain, A. B. M. Sonargaon - Panam: A Survey of Historical Monuments and Sites in Bangladesh. Ed. M. Harunur Rashid and Abdul Momin Chowdhury. Dhaka, Bangladesh: Asiatic Society of Bangladesh, 1997. 


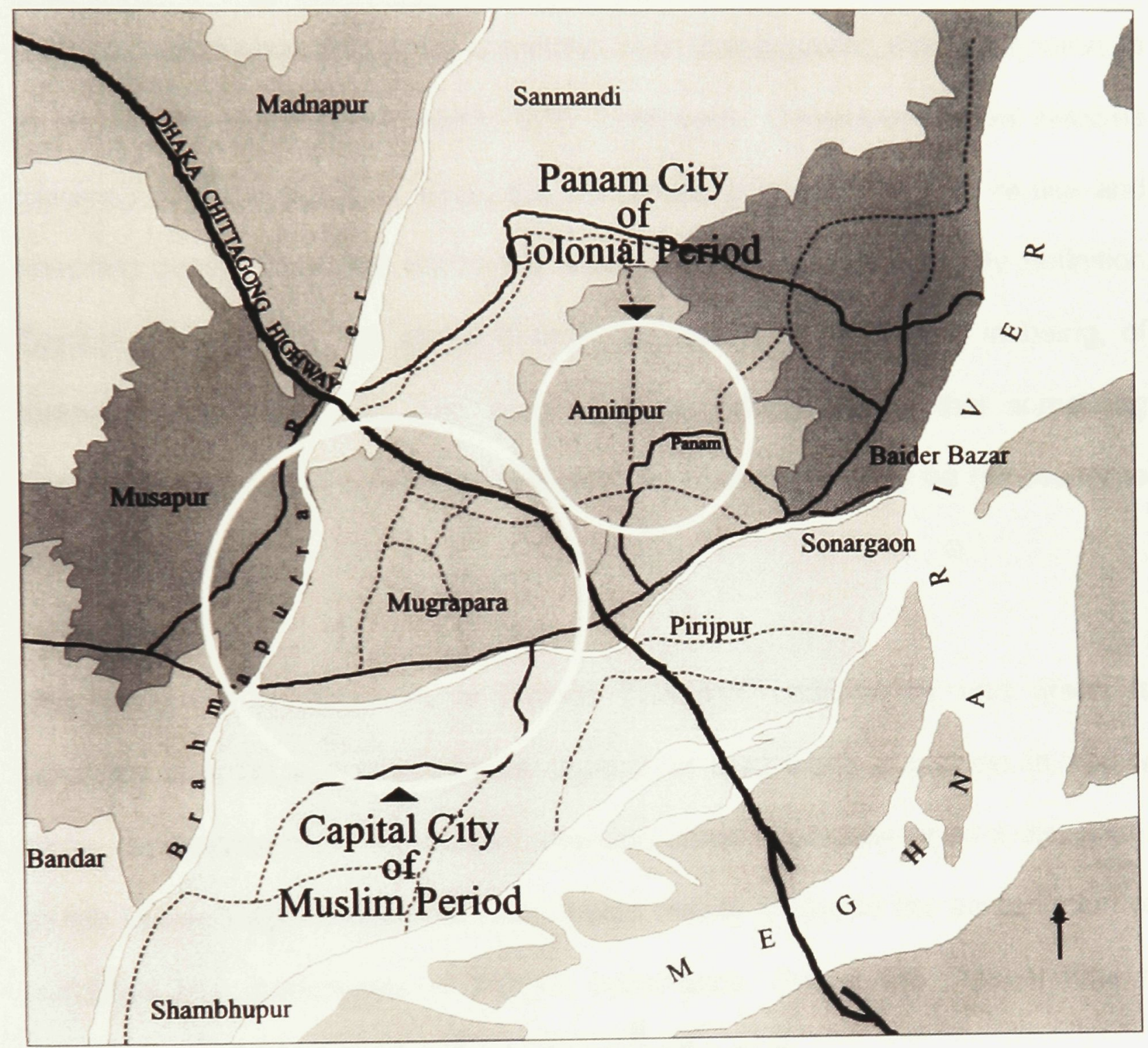

Fig 4: Medieval Sonargaon and Panam city.

Source: Folklore Museum, Sonargaon. 


\subsection{Objective of the research}

Historic preservation should be expanded from simply saving single monuments to conserving entire environments and social units. Conservation now involves planning on various social, economic and financial levels. Adaptive re-use and historical preservation fall within the wider term of conservation. By definition Conservation means the act or process of preserving something in being, of keeping something alive'. And in keeping something alive - that something ranging from a single building to a whole city quarter - it may be necessary to infuse new life.

The need for conservation of historic buildings, monuments and areas is relatively new on the development agenda of third world countries. In earlier times, conservation did not receive attention either in practice or as a discipline. In the earlier stage of this approach, it was mainly limited to the preservation of buildings and monuments of historic importance. But at the present time it becomes the most effective way of preserving the past.

Like many other areas of Bangladesh, Sonargaon possesses a large number of monuments and sites of historic importance which need to be conserved for larger socio-cultural and historical interests. At present, Sonargaon is under pressure for growth of new and unplanned development, which poses a 
tremendous threat by destroying the visual continuity and architectural integrity of this historic city. Therefore, it is necessary to take protective measures to preserve this area, while, at the same time, considering appropriate measures to upgrade and readjust the present encroachment with the essence of area conservation.

The buildings at Panam Nagar are under threat because of misuse and neglect. The primary objective is to stop further destruction and deterioration. This thesis is focused on finding the right means of conservation. Some buildings need to be repaired. Consideration of appropriate ways to restore damaged buildings presents a secondary aspect of this research.

Regenerating activity like trade, crafts and business may be a way of putting life into Panam Nagar. Formulation of appropriate policy and methods of implementation appear as the final objective of the thesis. 


\subsection{Importance of the research}

Sonargaon, which literally means "golden village", was the capital of the province Banga (eastern Bengal). It was also one of the three political units of this territory during the Delhi Imperial rule. In addition, the city was the seat of Deva Dynasty until the 13th century. From then onward untill the advent of the Mughals, Sonargaon was a subsidiary capital of the Sultanate of Bengal.

In 1338, Fakhr-al-Din-Mubarak seized the provincial government of Sonargaon and declared himself independent from Delhi. He was the first independent Sultan of Bengal. In 1352, he was overthrown by the Sultan of Gaur (Ilyas Shah), and from this time, Sonargaon formed part of the independent kingdom of United Bengal until the advent of the Mughals (1575). In the reign of Akbar, it was the chief city of Isa Khan, who maintained his independence for several years. After Isa Khan's death it became a part of the Great Mughal Empire. ${ }^{6}$

The decline of Sonargaon started with the establishment of the Mughal capital in Dhaka in 1608 , and with the conquest of the kingdom of Isa Khan by the forces of Islam Khan in 1611 , it began permanently to lose its former prestige. The history of Sonargaon for the next two hundred years until the establishment of the commercial belt of the East India Company in Panam is still unclear. The colonial city Panam came into being in the nineteenth century and continued to 
flourish untill the end of the Second World War.

Most of the monuments from ancient Sonargaon are lost forever. The city of Panam, with its streets and buildings, still possesses signs from the past, its past and our past. Although constructed at a much later phase, Panam is the only link to the glorious capital city of Bengal.

Unfortunately, the historical monuments at Panam have not been conserved well. Most of the structures have reached a state of decay. The government, as well as the people, ignore them and are not taking steps to save the relics. Not only are the people of Sonargaon area destroying the national heritage, some of them have also been dwelling in the old buildings, which is dangerous for both buildings and humans. If people continue to neglect and abuse these historical structures, the next generation will not be able to perceive their glorious past.

Sonargaon is not only a place of historical importance, it signifies the heritage and culture of Bengal. It holds immense architectural and archeological value. Such a concentration of multiple archeological sites covering a huge area is rarely found. It has become imperative that the area be conserved properly as a first attempt to bridge the discontinuity in history.

Some historians and critics have raised demands that the government declare 
the whole area of Panam Nagar as a museum, a move that would protect this unique place with its Sultanate, Mogul and European architecture, and also attract both students of history and visitors from home and abroad.

However, this thesis proposes that the ancient 'Panam Nagar' be given life once again through a transformation into a modern and active city. A new city will emerge from the ruins absorbed in the very same spirit that once existed in the golden capital of "Sonargaon". The business and trade activities that flourished in Sonargaon will be regenerated in the area around "Panam Nagar" and the city will be re-inhabited.

Conservation does not exclude demolition or new construction. It does not, in other words, exclude change. Without the ability to change, a city will die. A conservation policy for changing a city must take into account the wider planning issues. It must address itself not only to the problems of historic preservation, but also to new development and infrastructure. Such a policy must also take into account social and economic factors. The transformation of Panam Nagar will require a study of the history and evolution of the area, and a comprehensive analysis of the existing situation in comparison with the past, in order to find out the course of deterioration. 


\subsection{Scope and limitation of the research}

Panam Nagar is a unique archaeological site in Bangladesh. Such a huge assembly of buildings spread over a large area bearing testimony of a long history is rarely found, even in this sub-continent. Therefore, Panam offers great scope for any archaeological conservation work. Firstly, the research will provide vital data and reveal a great amount of knowledge regarding history and society. The information will also be useful in the study of architectural styles. Also such a project offers a restoration of heritage.

The proposed transformation will generate new activities in and around the city, creating scopes for new trades. The crafts industry, which reflects the original talent of the people, will also be rejuvenated.

Moreover, this place has the potential to become one of the major tourist attractions in Bangladesh. The research will facilitate all these possibilities.

There are some issues that can be considered as limitations. One particular problem related to adaptive re-use is the question of ownership and the various ways in which authorities try to gain control over property. Another issue, especially important for developing countries, is the source of funds. 
Bangladesh, being a tropical country, suffers from heavy rainfalls, floods and other natural calamities, which are constantly posing threats, particularly to buildings made of less-durable materials such as brick and wood. In consideration of this aspect, a suitable technique to preserve a building across centuries is hard to find.

Finally, lack of public participation is another common factor which creates adversities in any conservation or rehabilitation project in Bangladesh. Both the less educated and the poor fail to understand the significance and need for such developments.

In spite of some limitations, the research offers great potential to shed new light on the history and heritage of Panam Nagar, as well as the whole of the Sonargaon area.

\footnotetext{
${ }^{1}$ Hussain, A. B. M. Sonargaon - Panam: A Survey of Historical Monuments and Sites in Bangladesh. Ed. M. Harunur Rashid and Abdul Momin Chowdhury. Dhaka, Bangladesh: Asiatic Society of Bangladesh, 1997. 1

${ }^{2}$ Karim, Md. Razaul. SONARGAONER ITIHAS: Utsa O Upadan. Ed. Dr. Saikat Asghar. Dhaka, Bangladesh: Rahman Group of Industries, 1993. 9-11

${ }^{3,4,5}$ Hussain, A. B. M. Sonargaon - Panam: A Survey of Historical Monuments and Sites in Bangladesh. Ed. M. Harunur Rashid and Abdul Momin Chowdhury. Dhaka, Bangladesh: Asiatic Society of Bangladesh, 1997. 1-31

${ }^{6}$ Md. Mosharaf. BANGLADESHER NAGAR: Udhvab O Bikash. Ed. A. K. M. Shahnawaz. Dhaka, Bangladesh: Protik Publishers, 2001. 118-120
} 


\section{Chapter 2: Methodology}

\subsection{Approach}

Panam nagar is an ancient city in a state of ruin. Through this thesis, an attempt will be made to establish the origin and historical importance of this city and to find a proper way to put Panam back into a position, so it can continue to be the symbol of ancient tradition and glory.

A proper policy for achieving this goal can only be realized on the basis of physical survey, a literature study, a study of socio-economic conditions, an assessment of existing and future needs and a study of similar situations. Research on the above mentioned fields has been the general approach for the thesis. 


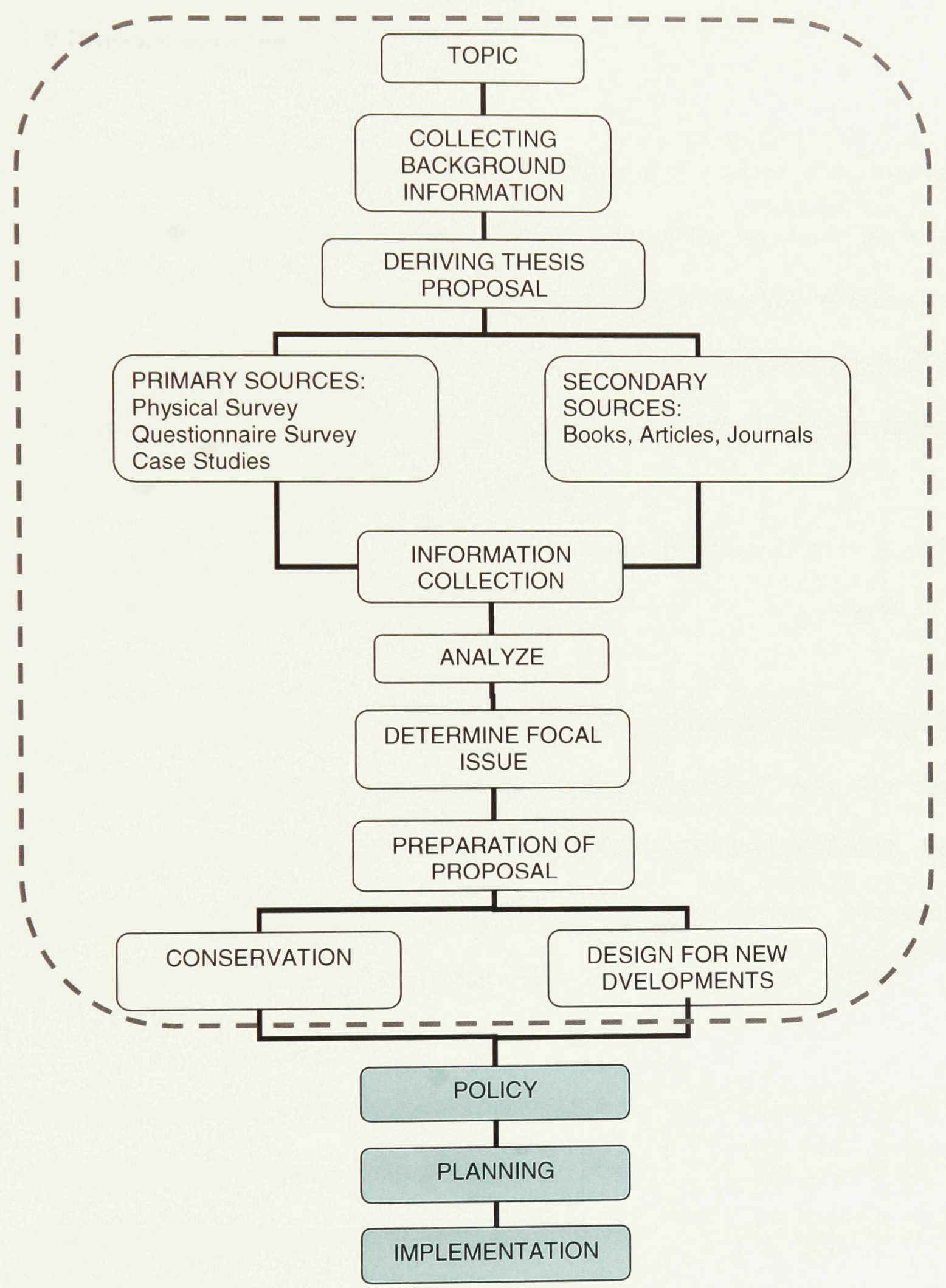

Fig 5: Process of research 


\subsection{Primary sources}

Sources that provide information directly related to the problem in question can be defined as primary sources. The site itself, a physical survey of the area, and interaction with local people are examples of primary sources. Primary sources are vital sources of information for any conservation project. A physical survey, case studies and a questionnaire survey were carried out during the research to gather information about the existing situation.

\subsubsection{Physical survey of existing condition}

First several field visits were made to the site. The preliminary visits helped to get acquainted with the area and locality. During the later trips, the site was photographed thoroughly, and the buildings were examined individually. Some of the buildings which are still in good shape, were noted, measured and documented. Moreover, the overall situation of the buildings was noted.

Site visits provided vital information needed to understand the existing situation of Panam Nagar and the surrounding areas. Photographs helped in analyzing the situation. Also Measurements and documentation were necessary to assess existing conditions. 


\subsubsection{Study of precedents}

Another source of information is the study of precedents. Conservation and rejuvenation projects have been undertaken in many countries including Bangladesh. A study of similar projects helps better to understand the problems and sheds light on the scope and prospects. These case studies also provide a guideline to carry out the research.

In Bangladesh, a number of conservation projects have been successfully completed. Among them, the restoration and conservation of Ahsan Manzil is notable. This project, along with the restoration projects of Old High Court Building, Chummery House and others were selected as precedents for study. Another situation similar to Panam exists in the Shakhari Potti area in old Dhaka and is a potential precedent. A project taken up for the re-use of nineteenth century row-houses in Istanbul also explores issues similar to the Panam Nagar.

\subsubsection{Socio-economic survey}

A socio-economic survey was also done as part of the physical survey during the visits to the area. Although the study of socio-economic condition throughout the history of 'Panam Nagar' has been mostly based on secondary sources, some observation and random surveys were done during field visits. Major economic activities of the local people, the composition of the population and the 
employment patterns were the concerned issues.

Panam Nagar is mostly inhabited by Hindu families. Hindu society is layered into several classes. The population now living in Panam consists of the various classes of Hindu religion. Today, the population is poor and has deviated from the family profession of trade and crafts, although many of them are descendants of rich Hindu merchants. In the glorious days of Panam, some of them were 'Jamindars' and 'Talukdars' (landowners).

In contrast, during the reign of the Sultans and the Mughals, Sonargaon was populated with Muslims. Society was divided into the high and low classes. The families serving the 'Nawab' or 'Sultan' were the aristocrats of society and the lower class consisted of the converted Muslims.

\subsubsection{Questionnaire survey}

During multiple visits to the site, a questionnaire survey was carried out among the local people. This type of survey is also a source of primary information. The purpose of the questionnaire survey was to know about the history of the area according to the local people, about the past and present condition of the people, their occupation patterns and socio-economic conditions, the missing links in history and gather information about the original owners of the buildings. The 
question of ownership is an important issue in the proposition of re-inhabitation. Participation of the people is needed to define the scope and prospect for a new township.

Hindus and Muslims lived in mutually exclusive areas. To the north and west, many of the villages had large Muslim populations and to the east Hindus had a predominant position. Panam did not have a single Muslim house. There were Hindu talukdars instead. The Hindu society contained Brahmans, Sahas, Bhuinmalis, barbers and others. The majority of the population consisted of wealthy merchants who used to make considerably large purchases in Dhaka and Calcutta and sold the commodities in the villages surrounding. At Panam, they made extensive trade in cotton fabrics.

More information on this survey is provided in the Appendix, section $\mathrm{H}$, page 150 .

\subsection{Study of secondary sources}

In addition to primary sources, a great amount of information has been collected from other sources, such as books, articles, journals and personal interviews. These sources, also known as secondary sources, mostly provide background information regarding the wider area of research and cover a large portion of the research. Many parts of the thesis are outcomes of the study of secondary 
sources. However, the literature has not been accommodated in any one chapter; rather references to this information are made at various points of the thesis. Secondary sources include:

\subsubsection{Accounts of travelers}

Travelers from all over the world have visited India and Bengal. Some of them have also visited 'Sonargaon Area' and have written detail accounts of their visit.

The most prominent among these visitors are Ibn Batuta, ${ }^{1}$ Ralph Fitch, ${ }^{2}$ Fei Hsin ${ }^{3}$ and Ma Huan ${ }^{4}$. The detailed accounts of their visits are available from various sources, including the Internet. This information has been included as references, especially in understanding the historical and socio-economic backgrounds of Sonargaon and Panam.

\subsubsection{Books, articles, reports}

Published books on history and other issues of Sonargaon were included in the study and were a vital source for most of the information. Many government and non-government publications also contribute to the development a knowledge base. Besides these, many references and information from the Internet were used to construct the thesis. 
Some of the most significant publications for this thesis are mentioned below:

1. Sonargaon - Panam: A Survey of Historical Monuments and Sites in Bangladesh.

Written by Mr. A. B. M. Hussain, this book provides the key information for the thesis. This book is part of a series published by the Asiatic Society of Bangladesh, based on the survey of some of the historical sites in Bangladesh. It contains valuable information gathered from the survey, and contributes greatly in the making of this thesis.

2. BANGLADESHER NAGAR: Udhvab O Bikash.

This book, is written by Md. Mosharaf Hossain, is a study of the evolution of cities in Bangladesh during the ancient period. The book takes a look at the establishment and evolution of the major cities that existed between the $6^{\text {th }}$ and $18^{\text {th }}$ century.

\section{SONARGAONER ITIHAS: Utsa O Upadan.}

This book by Md. Razaul Karim, a compilation of a large amount of published material regarding Sonargaon. The materials have been collected from a wide range of sources including travelers' accounts, drama, and old manuscripts.

4. History of Indian Subcontinent - Mughal Period. 
In this book, Mr. A. K. M. Shahnawaz elaborates on the history of the Indian subcontinent, including Bangladesh, during the Mughal period. This book is essential in understanding the historical context of Sonargaon and Panam.

\subsection{Data analysis}

The collected pieces of information were in different forms, including text, maps, drawings, statistics were analyzed in order to understand the existing situation, formulate the probable solution and define the policy for new developments.

The measured drawings and photographs were used to elaborate the existing situation. Many of the critical problems were identified and An analysis revealed which buildings are totally in ruin and which are still usable. It also revealed which buildings needed the most repair work and which did not. In addition, this data was used in deriving the proposed master plan.

The background information related to the history and society of Sonargaon helped to draw a picture of what Panam Nagar used to be, and based on that, a new vision of what Panam should be was derived. This vision is reflected in all proposals and recommendations made in this thesis. 


\subsection{Result of the survey and study}

The following chapters are constructed based on information collected from primary and secondary sources. During the physical survey it became evident that Panam Nagar is in dire need of attention. Ignorance and misuse have put this city on the edge of extinction.

The research revealed that multiple issues need immediate attention:

- Finding out the cause and remedy of destruction

- Establishment of legal ownership of the buildings

- Planning the growth of the city

- Reinstating local craft and trade

- Creating tourist attractions

These issues determine the course of the thesis, and suggest the need for a master plan. Vital information needed to build a master plan is also gathered from the studies. They include:

a. Architectural style of Panam Nagar

This shows the massive influence of the Colonial style created by British imperial rulers. Muslim and Mughal influences however, are visible.

b. Classification of the buildings Into three major groups:

- Religious Buildings (mosque, madrasa, temples etc.). 
- Landmarks (gateways, bridges, tombs and forts).

- Secular buildings

c. Listing of buildings suitable for adaptive re-use

Among the street, front row houses, no. 1, 2, 5 (old museum), 11, 16 (Niharika), 26 (Boarding House) and no. 38 (Kashinath House) have the potential for re-use. (ref. map)

Ananda Mohan Poddar's House (ref. map), largest of the compound houses at Panam, has great potential for re-use.

\section{d. Extent of restoration and modification needed}

Most of the buildings are on the verge of structural failure and need major restoration work. Some are in complete ruin and are beyond conservation.

The following chapters elaborate the mentioned issues and aspects in more detail before proceeding to the recommendations and proposals. The recommendations are also the result of the study of information collected from primary and secondary sources.

${ }^{1}$ Ibn Batuta (1304-1377): Moroccan traveler who visited Bengal during the reign of Sultan Fakhruddin Mubarak Shah (1338-1349) and left an account of his visit in his Rehla. (see Appendix, section D, pg. 144)

${ }^{2}$ Fitch, Ralph (d 1611): Traveler and trader. With the object of traveling in the East he came to India in 1583. (see Appendix, section E, pg. 145)

${ }^{3}$ Fei Hsin was one of the three officials who accompanied Admiral (Eunuch) Zheng-He during his voyages to the Indian Ocean in the early medieval period. (see Appendix, section F, pg. 146)

${ }^{4} \mathrm{Ma}$ Huan (Chinese traveler) was also one of the four officials who accompanied Zheng He (Cheng Ho) during his seven voyages into the Indian Ocean (called Western Ocean by the Chinese) between AD 1405 and 1433. (see Appendix, section G, pg. 148) 


\section{Chapter 3: Historical Sonargaon}

Sonargaon was the capital of ancient Bengal for many centuries. With the fall of the Mughal empire to the British in 1757, Sonargaon fell into oblivion and was forgotten.

In Major Rennell's Memoir ${ }^{1}$, published in 1785, Sonargaon is said to have "dwindled to a village". When Hamilton visited the area in 1809 , no one would give him any idea of the exact location of the lost capital.

During the British Colonial rule in India and Bengal, the saga of Sonargaon was revived with the emergence of Panam Nagar. In the middle of the 19th century, Panam Nagar was the abode of a group of wealthy Hindu merchants, who returned to set up their residences in the lands where their ancestors once ruled. The city existed for almost a hundred years in history, from the mid 19th century to the mid 20th century.

\subsection{Historical background}

It is difficult to determine the exact location of the medieval city of Sonargaon. Khasnagar, near the modern museum, is said to have been the administrative centre of the principality over which Dasaratha Deva, the Hindu king of Central 
Bengal during the medieval period was reigning. The pre-Muslim principality of Sonargaon was situated at the confluence of the Dhaleswari, Sitalakhya, the old Brahmaputra and Meghna and included Vikrampur with which communications were maintained across the river routes. The administrative headquarters of the Hindu principality had access to the Meghna along the Menikhali which seems to have shifted at a later time.

Although no traces of the Muslim capital can be detected at present, one can assume on archaeological evidence, that a rich and extensive Muslim settlement must have grown over the entire Mograpara and Goaldi region which contains Fath Khan's mosque, ruined buildings and tombs of Dargabari, Azam Shah's tomb, two mosques of Goaldi and other relics of historical importance. Even in the later part of the nineteenth century, the people of Mograpara used to believe that the capital city was located in this area. Every metropolitan city of medieval India including those of Gawr and Pandua, used to be built within a fortified space. But traces of fortifications are not found in Sonargaon, which now has only scattered buildings and tombs interspersed by human habitations, meadows, jungles and cultivable land. Near Azam Shah's tomb, a large area called 'damdama' or fort exists, which consists of a raised circular ground surrounded on three sides by low lands and on the south by the Menikhali river. It is believed that a fortification enclosing the royal palace existed at this place. ${ }^{2}$ But the absence of any traces of fortification in the 'damdama' area seems to negate 
this view. But to base a positive conclusion on a negative piece of evidence may be entirely misleading. James Wise advocates a similar view when he says that the fort stood on the coast of Baidyer Bazar where the Meghna flows. ${ }^{3}$ To accept this view, one has to presume the entire city has disappeared into the silt of the Meghna. On the archaeological evidence cited above, one has to assume that most of the residents, including probably some nobles and merchants, lived in the urban area of what is now known as Mograpara and Goaldi. When the administrative centers shifted to Muazzamabad towards the end of the fourteenth century, a considerable number from this population must have moved to this city. ${ }^{4}$

The Bandar area, bounded on the west by the Sitalakhya, which was connected with the Meghna in the east by an artificial canal known as the Menikhali river, had a gradual expansion in so far as its commercial prosperity and growth of population were concerned. In 1345, when Ibn Battuta visited the place, the port was of considerable importance. He found gold and silver coins in circulation to facilitate exchange and also a Chinese junk ready to sail. ${ }^{5}$ But in the fifteenth and sixteenth centuries, wealthy merchants must have settled in Bandar to participate in the growing economic activities of Sonargaon and Muazzamabad. ${ }^{6}$ At present there are two Sultanate mosques here built by Haji Baba Saleh and his tomb. Several inscriptions recovered from this place indicate that there were similar other buildings here to meet the needs of the growing population of the port. ${ }^{7}$ 
Muazzamahad, about $20 \mathrm{~km}$ north of the Dhaka city and situated on the bank of the old Brahmaputra, was a mint town, an administrative headquarters as well as a port of considerable importance. As it was the heart of an iqlim (literally 'kingdom'), it must have occupied an extensive area peopled by officials of high positions, merchants and scholars. The Sultanate mosque constructed in the early part of the 15th century and the tomb of Shah Langar found at this place, do not speak of its former glory.

James Taylor has expressed the view that Panam was the capital of Sonargaon in the Sultanate period, without adducing any evidence in support of his opinions. ${ }^{8}$ But Panam does not possess any building that can be dated to the pre-Mughal period.

In all probability, Panam grew as a by-product of the commercial activities of the English East India Company and the Permanent Settlement. The existence of two Mughal bridges at this place and the lakes enclosing it on the three sides perhaps indicate that it was a suburban area of the medieval city.

While pointing to the historical importance of the places mentioned above, one has adequate reasons to believe that at the present stage of knowledge, it is impossible to determine the exact location of the capital city of Sonargaon. Gawr 
and Pandua are very fortunate in this respect. Their ruins, though scattered over large areas, give a positive clue to the positions they occupied at different periods of time on the bank of the Ganges. But it is clear from the account of FeiSin and the early 17 th century work of Baharistan-i-ghaybi, that the metropolitan city of Sonargaon and Bandar were both well-fortified urban centers. ${ }^{9}$

Although most of the governors of Bengal in the early Sultanate period had the natural tendency to defy the Delhi authority either tacitly or by declaring independence, Shamsuddin Firuz (1301-1322) issued coins in his own name from several mints including that of Sonargaon. ${ }^{10}$ Taking advantage of the process of disintegration through which the Delhi kingdom was passing, local adventurers in Bengal tried to establish a dynastic rule for themselves. Out of this political chaos the independent Sultanate of Bengal came into being.

During the period of $1338-1333$, Sonargaon enjoyed the status of a capital city under the house of Fakhruddin Muharak Shah. In fact, Sonargaon began to appear as a mint town on the silver coins of Shamsuddin Firuz, the earliest one dating 705 A.H/1305 AD. His son and successor Ghiyasuddin Bahadur (13221328) struck silver and gold coins from this mint. On the gold coins dated 728 A.H/ 1328 A.D., he added the epithet 'hadrat' to Sonargaon to indicate the political importance of the town. Fakhruddin Mubarak also issued a gold coin in 739 A.H./1339 A.D. on which Sonargaon has been termed the hadrat 
Sonargaon. His silver coins issued from Sonargaon bears the expression "hadrat jalal', which indicates that the place had become by that time a royal residence. This appellation appears also on some silver coins of llyas Shah (1342-1358) and his successor Sikandar Shah (1355-1393). Thus, numismatic evidence points to the political and commercial importance of Sonargaon. ${ }^{11}$

An inscription issued in the reign of Husayn Shah, indicates that Muslim rulers were expanding their territories using Muazzamahad, the new mint town near Sonargaon, as the military base. Although Sonargaon was no longer a mint-town, it was probably placed under a governor who had to attend the court of Gawr. The Portuguese mission, which came to Gawr in 1521, noticed a well-decorated big ship on the Ganges, which belonged to the Governor of Sonargaon. The port or Bandar seems to have been serviceable when Islam Khan's forces occupied it in the beginning of the seventeenth century.

It is very difficult to trace the growth of the city of Sonargaon. The present day Dargabari area seems to have been the earliest Muslim settlement. Sharafuddin Abu Tawwama, a great Hanafi scholar, came from northern India in the last decade of the thirteenth century to settle at this place where his tomb is found, together with those of some other saints. He established here a madrasa and a khanqa to teach both religious and mundane subjects. Adjacent to his tomb, a large area is shown to have contained the Abu Tawwamas madrasa. It is 
interesting to note that in this area, there are two Gawripattas or the lower parts of Saivic phallic symbols. In those days, khanqas used to be erected on the ruins of earlier Hindu Buddhist temples and shrines with a view to attracting devotees of different ethnic affiliations. The place has a Sultanate mosque, which was renovated in the Mughal period. One does not know if the earliest administrative headquarters were also established near the madrasa complex. Some of the ruined buildings of the place are called tahkhana, takshal, or naubat khana, which indicate that the place was later on associated with an administrative centre of considerable importance.

It is perhaps no mere accident that Abu Tawwamah's arrival at Sonargaon almost coincided with the conquest of Bang by Ruknuddin Kaikaus, who issued a coin in 1281 from the kharaj of this newly conquered territory, and that Bengal rulers like Shamsuddin Firuz struck coins from the mint of the city of Sonargaon as early as 1305. Solely territorial conquests would be meaningless unless followed by a process of peaceful conversion, and also by the building of religious and cultural institutions to educate converts. In other parts of Bengal, Muslim conquerors, warrior saints and peaceful Sufi missionaries cooperated with one another in order to strengthen the material and moral base of the newly established state system.

Fakhruddin Mubarak Shah (1338-1349) was the first Muslim ruler to establish an 
independent dynastic rule centering around Sonargaon. ${ }^{11} \mathrm{He}$ expanded his kingdom in the south-eastern direction by conquering Chittagong, which he connected with the metropolitan region by a road connecting the city and Chandpur opposite Sripur. The remains of this road were known until recently as the Fakhruddins Path. The early Ilyas Shahi rulers (1353-1415), the house of Raja Ganesh (1415-1435) and the Husayn Shahi Sultans (1494-1538) had direct control over Sonargaon. Two inscriptions of Jalaluddin Fath Shah (1481-1487) issued from Bandar and Muazzamabad in 1481 and 1484 respectively, show that this ruler and other Sultans of his dynasty ruled over this region. Although one knows nothing about the Abyssinian rulers' (1487-1494) relationship with Sonargaon, there seems to be no violent dislocation in its political history. Also, Alexander Cunningham detected in this region traces of the Grand Trunk Road constructed by Sher Shah (1538-1545). An inscription dated in 1569, shows that a mosque was constructed somewhere near Rekabi Bazar in Sonargaon in the reign of Sulaiman Karrani (1564-1574). But one does not know how effective the hold of the Surs and the Karranis was in this region. ${ }^{13}$

Sonargaon developed into an independent kingdom under Isa Khan, chief of the Bara Bhuiyans. Before his death in 1599, Isa Khan had brought under his control parts of the Dhaka, Tippera and Mymensingh districts and some portions of Rangpur, Bogra and Pabna. These extensive territories were inherited by Musa Khan, Isa Khans son and successor. For his political supremacy, Musa Khan 
was dependent on the strategic region south-east of Dhaka. Lying at the confluence of the Padma, the Lakhya and the Meghna, it provided him with an impenetrable natural defense. Also, the well-protected capital city of Sonargaon, about 3 miles $(5 \mathrm{Km})$ east of Khizirpur and 9 miles $(15 \mathrm{Km})$ south-west of Dhaka had a famous port which seems to have been protected by fortifications. Most of these places located at the confluences of rivers, gave to Musa Khan rare facilities of natural defense. Depending on these fortified positions and assisted by the coalition of twelve chiefs he had formed, Musa Khan fought the Mughal forces $\mathrm{He}$ gave stubborn resistance to his formidable enemy by erecting temporary fortifications and attacking them with unexpected suddenness, particularly at Dakchara and near other strongholds. But the able generals of Islam Khan with their superior strategy and effective technology were able to occupy all the posts including Sonargaon, which fell to the Mughals in 1611.

Sonargaon, as one of the Sorkars of the Bengal Suba, had 52 mahals, in addition to the divisions and towns of Isa Khan's kingdom. In Raja Todar Mall's arrangement, the Brahmaputra shown as the western boundary of Sonargaon, is probably identical to the old Brahmaputra, which was a large river in those days flowing at earlier times along the course of what later came be known as the Menikhali River. The Sarkar of Sonargaon was bounded on the east by the independent kingdom of Tippera and on the north by Syihet. 
Sonargaon became an insignificant place so that the European writers had no proper idea about its location. In Major Rennells 'Memoir' published in 1785, Sonargaon is said to have dwindled to a village. When Buchanan-Hamiltion visited the area in 1809 , his informants could not give him any idea about its exact location. ${ }^{14}$

The road which leads from Panam in the direction of Kothibari has a steep bridge, which was constructed in the Mughal period. This road looks like the dividing line between medieval Sonargaon and the Panam township, which came into being in the nineteenth century and continued to flourish until the end of the second World War. On the south, east and north, Panam is surrounded by artificial lakes which used to protect it from the intrusion of the robbers. At present, it looks like an empty township deserted by the original inhabitants echoing the vibration of a life primarily based on trade and commerce. A group of talukdars, who came into being from among the traders in the nineteenth century, chose this place as their residence and used to pay the revenue direct to the Dhaka treasury. Apart from the talukdars, the majority of the people were traders and money-changers. 


\subsection{Society}

It is possible to detect several classes in the society that existed in medieval Sonargaon. At the top of the social hierarchy there was the Sultan decorated with a number of regal titles and possessing an impressive court, a well protected palace and other kinds of royal paraphernalia. He was the pivot around whom the entire administrative machinery and the cultural life of people of upper social grades evolved. Below the Sultan, there was a military aristocracy, mostly consisting of Turkish, Arab, Habshi, Iranian, Afghan and Mughal origins. The nobles and generals very often had decorative titles conferred upon them according to their ranks and possessed perhaps land assignments. The highest executive officer in a province or in charge of a town had the titles of wazir (literally minister; but, in reality, a high-ranking official controlling financial affairs) and sarlashkar (commandant) sometimes in combination with jamdar ighayrmahalli (extra-ordinary ward-robe keeper). ${ }^{15}$

The Sufis and the Ulama, generally regarded as religious groups, played a significant role in the religious and cultural life of the country. Sharafuddin Abu Tawwama, Yahiya Maneri and their disciples, and Alaul Haq, Shaykh Anwar and Shaykh Zahid, were known for their personal piety and learning. ${ }^{16}$

The upper class could be distinguished from the lower classes of the Muslim 
population who were converted Hindu, Buddhist and tribal people, and who represented a variety of professions hardly distinguishable from those of their non-Muslim neighbors. Economically, weavers and cultivators were probably the more important groups of Muslims. It is not known how much tension existed between the ashraf (Noble man) and the atraf (Commoners) but it seems to have been acute in the Mughal period.

Hindus belonged to various castes. The Brahmans, Vaidyas and Kayasthas were at the top of the society. A considerable number of them formed the landed aristocracy functioning as the "Zamidnars" and different kinds of revenue-farmers. Mixed castes included such professional groups as karanika (scribe), ambastha (physician), tan travaya (weaver), gandhavanika (dealer in spices), napita (barber), karmakara (blacksmith), kumbhakara (potter), kamsakara (worker in copper and brass), varajibi (betel-vine dealer), modaka (sweetmeat-maker), sutradhara (carpenter), suvarnakara (goldsmith), suvarna vanik (dealer in gold or bullion), tailakara (oilman), saundika (vintner), jalika (fisherman), chandala (an untouchable caste), charmnkara (leather-worker), ghattajivi (ferryman), and dolavahi (palanquin-bearer). A number of tribal and lower-class groups could be regarded as antyaja or untouchables placed outside the boundary of the caste hierarchy.

In the absence of concrete archaeological and literary evidence, one can accept 
a theoretical framework of the caste system, ideally existing in Sonargaon. One has good reason to believe that Vikrampur, a centre of caste rigidity accentuated by Sena orthodoxy, very often formed a part of Sonargaon. ${ }^{16}$ Therefore the social classes of this region were not likely to be very different from those existing in Vikrampur. It may be mentioned here that a caste represented a profession as well as a particular ritual status for the group of people who belonged to it.

During the end of the $17^{\text {th }}$ century, the Hindu-Buddhist society of Sonargaon was going through a process of religious transformation. Because of the caste distinctions characterizing this society, along with the simultaneous presence of a convincing faith presenting new ideas through missionary and administrative agencies, people began to convert. There came into being a new society which had inseparable ethnic and linguistic affiliations with its Hindu-Buddhist and tribal counterparts. How far conversion could change or transform the social or economic status of people is a moot point. The caste ethos, which permeated professions in the Hindu society, was now brought into the new social order. The masons, fishermen, dancers and similar other lower groups were ajalachala sudras or low-caste Hindus, from whose hands Brahmans would not accept water. Although some of these people of low-class origins had accepted Islam, their professions as well as their social status did not change. Thus, indigenous Muslim social classes were but the counterparts of the Hindu castes tied to their original professions. 
Contrasted with these lower-class Muslims, who had a wide variety of professions as well as totemistic and animistic inclinations, indistinguishable from those of their Hindu-Buddhist neighbours, the upper class consisted of Arab, Turkish, Persian, Afghan and Mughal elements. While some of the immigrants had established dynastic rule, others constituted what may be called the nobility as well as the Ulama. There was hardly any communication between the upper and the lower classes of Muslims. This state of social isolation characterized the Muslims down to recent times. In the Mughal period, the people of alien identity came to be known as ashraf ('refined,' noble'), whose aristocratic lifestyle made them a distinct group in the Muslim society.

Traces of residential buildings do not exist at present in Sonargaon. The proverbial Isa Khan's gate near Panam, and the Naubat Khana and Tahkhana buildings in the Dargabari area indicate nothing about the brick-built houses of the upper-class people who had probably a life pulsating with wealth and luxury. No trace of the royal palace can be detected in the midst of the ruins which are found in the area. Sonargaon was the capital city of Bengal only for a short period of time, although as a provincial town, it had a longer life. It seems that the ups and downs of an unsettled political life that Sonargaon had experienced for a long time, prevented stately royal buildings from coming into being. Ibn Battuta has indicated how slavery and homosexuality were prevailing in a section of the 
people in the port area, which was visited by foreigners including merchants. Ethnically the upper class people of Sonargaon were not much different from those of Gawr and Pandua. So, the different accessories of life of the former were probably identical with those of the latter. David McCutchion has contended that the do-chala type of thatched huts originated in eastern Bengal. ${ }^{17}$ This kind of hut was made in the villages by the poorer classes. Ralph Fitch, who visited Sonargaon towards the end of the sixteenth century, states that the houses in this region were covered with straw, and had few mats round about the wall and door to keep out tigers and foxes. 'Many people are very rich. Here they will eat no flesh, kill no beasts; they live on rice, milk, and fruits. They go with a little cloth before them, and all the rest of their body is naked.... ${ }^{18}$ It has been said that the houses of these people were 'elevated above the highest tides as the whole area was traversed by many canals and natural creeks'.

The distribution of population in Sonargaon, as mentioned by James Wise about 125 years ago, indicates how Hindus and Muslims also lived in mutually exclusive areas in earlier times. To the north and west of Mograpara, nine-tenths of the villages had Muslim a population and in those to the east, Hindus had a predominant position. Panam did not have a single Muslim house but contained ninety Hindu talukdars. The number of castes was as follows: thirty houses of Brahmans, sixty-five Sahas, five Bhuinmalis and the remainder were barbers and others. The majority of the population were wealthy merchants who used to make 
considerably large purchases in Dhaka and Calcutta and then sold commodities in the villages around. At Panam, they carried on an extensive trade in cotton fabrics and chiefly English piece-goods. Most of these merchants and talukdars were absentee landlords who could be found here only in the autumn to celebrate the Durg-Puja festival, to which the Muslims of the area were also occasionally invited. Rathayatra or the procession of Jagannath's chariot, used to take place in the fairer half of the month of Asadh. About 25 years ago, one could see a ratha properly housed in Panam.

\subsection{Culture}

Islam spread rapidly in Sonargaon, after it had been conquered by the Muslims towards the end of the thirteenth century. This is proven by the extant mosques in Bandar, Mograpara and Mahjampur and also by those mentioned in the epigraphic records discovered in this area. Haji Baba Saleh, who lies buried in Bandar, built a number of mosques in the port towards the end of the fifteenth and beginning of the sixteenth century. He went to Mecca and Medina to perform hajj and visited also the footprints of the Prophet. Sharafuddin Abu Tawwama, the founder of the madrasa-khanqa complex of Sonargaon and Taqiuddin who lived in the reign of Nusrat Shah (1519-1532), was a great specialist in 'fiqh' and 'hadith'. In fact, the Ulama and the Sufis could convert a large number of people and thus built up a Muslim society of considerable importance. 
Mosques, madrasas and khanqas were centres of learning and probably symbols of proselytisation. Abu Tawwama's madrasa was a great institution, which attracted students from different parts of the sub-continent. This scholar was a specialist in jurisprudence and traditions, and possessed an adequate knowledge of chemistry and of the natural and occult sciences.

Hinduism, in its puranic and animistic form, seems to have been deep-rooted in the country. Danuj Ray, the Hindu king who reigned in Sonargaon towards the end of the thirteenth century, was a vaisnava. Gawri-pattas found in Dargabari also, indicate that the fertility cult was popular in a section of the Hindu population.

The coins of Danuja-mardan and Mahendra (identified by N. K. Bhattasali with Raja Ganesh and Jadu respectively) issued from Suvarnagram in the early fifteenth century, styled them to be dedicated to the feet of Chandi.' At about this time of interest, many works on Tantricism were composed in Mymensingh and Tippera, which borders Sonargaon. Sakta-tantric elements could probably be detected in the Hindu religious life of the country. Beliefs in legendary stories led to the growth of such places of pilgrimage as Langalband and Panchami Ghat on the Brahmaputra, where many Hindus used to take ceremonial bath in the month of Chaitra when the moon was in a certain lunar mansion., ${ }^{19}$ 
During centuries of Muslim rule, a considerable number of ethnic and culturally diverse peoples came to this region to add to its historical complexity. Turks, Persians, Arabs, Abyssinians, Afghans and Mughals shaped the history and culture of Sonargaon, where before one could notice Hindus, Buddhists and tribal people of Mongolian origins living since the pre-Muslim period. It can hardly be believed that these groups of people could have always lived in a state of isolation, thereby retaining their own racial and cultural identity. There must have been mingling of people through marriage and conversion, creating a situation of race-color complexity, which characterized the people of the entire Gangetic Delta.

As in the earlier period of Muslim rule, so also during the times of Isa Khan and his son and successor, Musa Khan, the Muslim rulers had to depend upon Hindu officers and Hindu revenue farmers and tax-collectors who had a better knowledge of the peasantry. Although the administrative affairs at the central positions could be controlled by the military aristocracy of foreign origin, these groups of Hindu gentry and nobles had control over the local affairs at different levels of the society. Hindu officers were appointed to important administrative positions. Ramai Lashkar and Janaki Ballabh were commanders of the Musa Khan's land army and Mathuresh, Musa Khan's court poet, wrote Sabdaratuabali, a Sanskrit dictionary, Hindu Zamindars joined the coalition which this 
ruler had organized against the Mughals, and fought the Mughal forces desperately. In fact, feelings of a regional affinity grew among these Hindu and Muslim rulers, when they had been giving resistance to a common enemy.

Ibn Battuta founded Sonargaon in 1345 A.D. at the initial stage of its growth. The diversion of the international trade route from the Persian Gulf area to the Alexandria-Cush-AdenCambay-Malacca line, coupled with the growth of Malacca in the east and Cambay in the west, and the gradually increasing demand for spices in Europe which expedited the production of industrial goods, particularly cotton fabrics, in the coastal regions of the sub-continent, accelerated the progress of trade and commerce in India, in the fourteenth and fifteenth centuries. Sonargaon, a feeder port in this commercial system, naturally had a share in the international trade. Corresponding to this centre of commerce, there was on the opposite side of the Meghna, another port, called Sripur, located at its confluence with the Kirtinasha. Ships could easily move from these ports towards Chittagong, Malacca in the Malay Peninsula and Samudra-Passe of north Sumatra. Naturally, wide varieties of cotton cloth and a considerable quantity of rice produced in this region could reach different parts of India, Ceylon and South-East Asia. So the economy of Sonargaon and also that of other parts of Bengal, were enriched by a stable monetary system as well as by a mercantile community, which must have grown centering around these important trade centers. As administrative centers of considerable importance, Sonargaon and 
Muazzamabad could acquire the additional dignity of metropolitan mint-towns. Naturally a cultural elite could flourish at each of these urban centers adhering to their own life-style.

The decline of Sonargaon started in 1608 with the establishment of the Mughal capital of Bengal in Dhaka, and with the conquest of the kingdom of Isa Khan by the forces of Islam Khan in 1611, it became one of the sarkars of the Bengal subah and lost it former political prestige forever. Mughal governors had to erect fortifications at Hajiganj and Sona Kanda to prevent Magh depredations, which must have devastated the cotton producing rural areas as well as the centres of textile production. But in reality, the decay of cotton manufacturers began when the English East India Company adopted a calculated policy of destroying artisans and industrial institutions of Bengal, with a view to accelerating the progress of the Industrial Revolution in England in the latter part of the eighteenth century. 
${ }^{1}$ Rennell, James (1742-1830): English cartographer, geographer, and oceanographer. He constructed the first approximately correct map of India (1783). (see Appendix for more)

${ }^{2-7,11-18}$ Hussain, A. B. M. Sonargaon - Panam: A Survey of Historical Monuments and Sites in

Bangladesh. Ed. M. Harunur Rashid and Abdul Momin Chowdhury. Dhaka, Bangladesh: Asiatic Society of Bangladesh, 1997. 1-51

${ }^{8}$ Taylor, James. A Sketch of the Topography and statistics of Dacca. Calcutta, India, 1840.

${ }^{9}$ Karim, Md. Razaul. SONARGAONER ITIHAS: Utsa O Upadan. Ed. Dr. Saikat Asghar. Dhaka, Bangladesh: Rahman Group of Industries, 1993. 99-110

${ }^{10} \mathrm{Md}$. Mosharaf. BANGLADESHER NAGAR: Udhvab O Bikash. Ed. A. K. M. Shahnawaz. Dhaka, Bangladesh: Protik Publishers, 2001.

${ }^{19}$ Karim, Md. Razaul. SONARGAONER ITIHAS: Utsa O Upadan. Ed. Dr. Saikat Asghar. Dhaka, Bangladesh: Rahman Group of Industries, 1993. 118-131 


\section{Chapter 4: Present condition}

\subsection{Present condition at Panam}

The concentration of existing buildings is seen only at Panam Nagar and its surrounding areas. In addition the city of Panam has been in existence since the later half of the Colonial rule in this region. The vast extent of the ancient Mughal and Muslim Sonargaon has been diminished by time. Therefore, the research site for this thesis has been confined to the township of Panam and nearby areas.

The surviving buildings of Panam from the Colonial period show a significant shift in architectural concept, character and building typology from the preceding Mughal and Muslim periods. Buildings were secular in nature, predominantly residential houses, as opposed to religious structures that characterized the architecture of earlier phases. Architecture entered into a private realm that prompted individuality based on certain shared values. Buildings increased in volume and complexity. Also uniformity of building craft, material and structure generated a harmonious pattern of development. The decorative treatments were transposed from European architecture and blended in places with local motifs. It was a period of eclectic architecture engaged in the metamorphosis of local and western ideas in domestic design and living. 


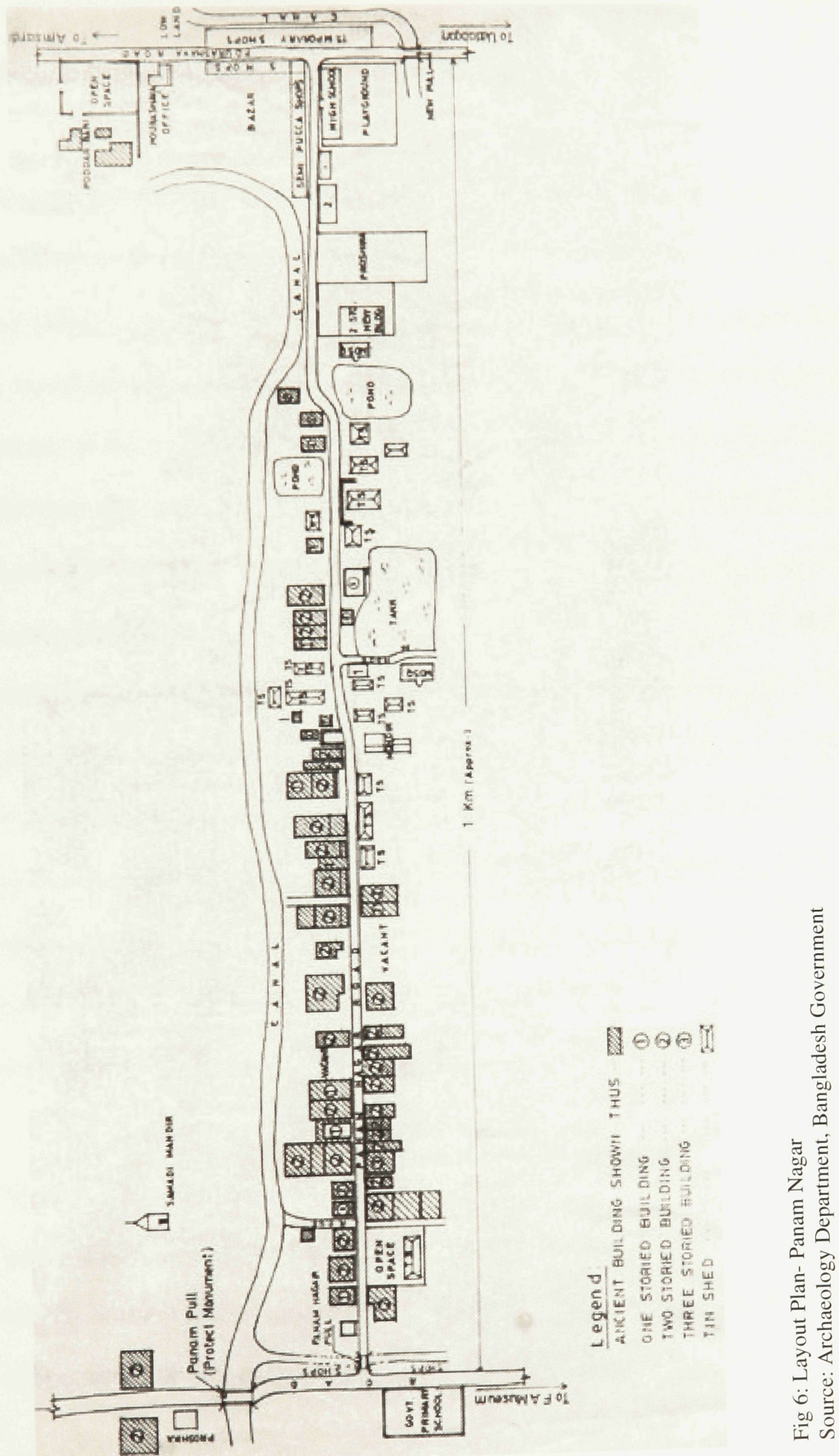




\subsection{Architectural Style}

Though Sonargaon was the capital of Muslim rule between 1296 and 1608, and developed as a centre of Islamic culture from the latter part of 13th century on, the Muslim dominance declined in the Colonial period and the area stagnated for a considerable period. The lavishly built residential buildings represented a phase of economic affluence of Sonargaon during colonial rule that flourished between the late 19th and early 20th centuries. This development was, however, confined to Hindu settlements. Hindu communities always lived alongside maintaining a socio-religious border dividing the Hindu and Muslim settlements. ${ }^{1}$ Mohollas to the north and west of Mograpara were dominated by the Muslim population, and those on the east were populated by the Hindu majority. Patterns of physical development and architecture in those localities were also regulated by the respective socio-religious rules of spatial organization. Some of those rules are still very clearly visible. For example, the shape of ponds in Hindu settlements is north-south elongated and, in Muslim settlements, these are eastwest extended.

During the colonial rule, architecture appeared as a means of personal gratification by the emerging merchant class. In Panam, the Hindu merchants, locally known as Shahas and Poddars, were the main contributors of the monuments of the colonial period. Their approach was distinctly 
different from the traditional concept of simplicity in domestic design. They indulged in building luxury dwelling houses instead of spending on temples. Rather, the temple eventually became part of the house. Therefore, there is not a single evidence of any surviving independent temple of comparable quality with the palatial houses in Panam. There is only one reference of a modern and ugly temple of Shiva in Panam in the Notes of James Wise (Jan. 1872). The locally known religious site in Panam identified as 'Thakur Bari', was also developed with insignificant regular structures as it is evident from the ruins in the plot. ${ }^{2}$

The domestic houses, on the other hand, were highly romanticized with extensive ornamentation, to celebrate the wealth and power of individual owners. Besides the residential buildings, there are remains of other structures like the 'Neel Kuthi' built by the British for trading and administration of the Indigo plantation and 'Krori Bari' built earlier by the Mughals as a treasury house. In architectural design and character, they are not very different from those merchant houses, though the influence of Mughal architecture is clearly visible.

\subsubsection{Patterns}

The residential built forms in Panam followed two distinct patterns with respect to location and layout. In pattern one (fig. 7), the building occupied the central position in a large compound surrounded by land developed with ponds, trees 
and gardens. The other pattern is urban in nature, in which large and small buildings were lined up in a row along a road, having considerably large backyards with ponds, wells and trees.

The first pattern may be referred to as Compound Houses. They belonged to a fabulously rich merchant class. The houses were built with a complex mix of structures to serve diversified domestic demands in connection with affluent living. The examples are Bara Sardar Bari, Ananda Mohan Poddar's house, Hashimoy Sen's house and Bhanu Babu's house near Panam. The other pattern may be referred as 'Street Front Houses'. All the houses of Panam Nagar and Damdama area have the character of urban Street Front Houses. The Street Front Houses were placed in a row with little or no space from the road. The heights of the houses vary from single to three stories. Buildings represent considerable variety in quality and content of architectural design. Therefore, it is presumed that the buildings do not represent a uniform economic class of their users or owners. A shared use of backyard facilities among the adjoining houses can be observed from the layout of ponds, ghats and well.

\section{Pattern 1: Compound Houses}

The compound houses followed the model of the Colonial Bungalow compound complex. Ironically, the Bungalow compound complex was developed in India in reference to the traditional rural architecture of Bengal. The improvised model 
became a symbol of colonial power, and the typology was extensively used in civil and police lines in colonial urban development. The basic characteristic was to place a one or two storied main house in the middle of a large compound, with a garden of fruit and flower all around, and to place subsidiary service structures at a distance with the accommodation of domestic service people further down, and away from the main building. Since this was a powerful available model of domestic architecture, it was an obvious preference of the affluent merchant class. Nevertheless, the model was modified to suit the needs and desires of the local people. The main differences in Sonargaon are that the buildings are much more massive and elaborate in plan than the Colonial Bungalows, to suit diversified social demand. Colonial Bungalow had different domains for the separation of locals and non-locals. Since such separation was not necessary in the local version, the secondary structures were either an extension of the main building or additive units placed close to it. The importance of the domain is expressed through interior and exterior decoration and finishing, the location with respect to the approach, and the orientation in reference to view and climatic conditions. The complexity of creating different social domains in the house and providing respective privacy gradients required more than one court in the house. The application of the inner courts responded effectively with the demands of social domains and the climatic adaptation of the house. Therefore, in all the examples of compound houses in Sonargaon, we find the existence of more than one court as the regulating element of design and layout. 
The Sardar Bari: The house, located $460 \mathrm{~m}$. south of Panam Nagar, is one of the most refined examples of compound houses. This has now been converted into the Folk Art Museum. The structure, built in 1308 B.S. (1901 A.D.), was designed with a double court. The main court on the south is square in shape measuring $15.24 \times 15.24 \mathrm{~m}$. The rear court is oblong-shaped, measuring $15.24 \times 7.62 \mathrm{~m}$. In addition, the courts are connected by corridors. There are seventy chambers of different sizes arranged around the two courts of the double-storied structures.

The main entry to the building is through an arch-way on a relatively lower and highly ornamented gateway structure on the south. The majestic facade of the building is on the west, overlooking a pond. Two equestrian statues are placed flanking the steps leading down to the pond. The west facade is projected forward at two ends and designed with nine arched openings both in the ground and upper levels. The upper floor openings are slender in proportion. A highly ornamental parapet with floral decoration is placed on the top. In the main axis of this facade inside the front court, a huge recess with high columns had been designed to accommodate a Krishna temple. To give further emphasis to the temple axis, two massive parapets were built on the east and west facade of the court that dominate the skyline. The temple facade is profusely decorated. The second court on the north was designed as an informal court and, therefore, it is relatively simple in character. All other facades of the building were left 
unornamented with doors and windows placed directly on the walls with minimum technical details. The building complex sits in a large compound isolated by the natural barrier of canals. The building is under a slow process of conservation by the Archaeology Department.

Ananda Mohan Poddar's House(fig. 7): This is another mature example of the compound house. Located on the north of the Panam township and approached through the thana road from the Panam Bazar, the house is placed $20 \mathrm{~m}$ away from the road on the west. The name of the house is 'Sonajil'. Locally, it is also known as 'Awal Manzil', since the ownership was transferred from the original owner Ananda Mohan Poddar to a person called Awal. This building is popularly referred to as a house of hundred and one rooms and is oblong in shape measuring $125 \mathrm{~m} \times 80 \mathrm{~m}$, elongated in the north south direction. The layout is composed around two courtyards. The house is approached from the north and the courtyards are placed in the central axis, one in the north and the other in the south. There are two ponds facing the north and south facades. Both the ponds are provided with ghats or steps leading to the pond. The southern pond is protected by the retaining wall. There is an annex building that is linear in shape, extended in east-west direction and located at north-west corner of Poddar's house, facing a lawn. The exterior facade treatment of the house is relatively simple, with straight forward arched openings placed at regular intervals. Contrary to the outside, the courtyard enclosure walls on the inside are 
extensively decorated with large and small pilasters and floral decorations over the arch, cornice and parapet. It is important to observe that the quality and intricacy of decoration is sequentially intensified from the bottom towards the top. The main building is badly damaged and is unsuitable for use, and only the annex building is being used for living accommodation. The building complex includes a specially designed enclosed flower garden at the north-east corner of the main house on the right hand side of the approaching road. 


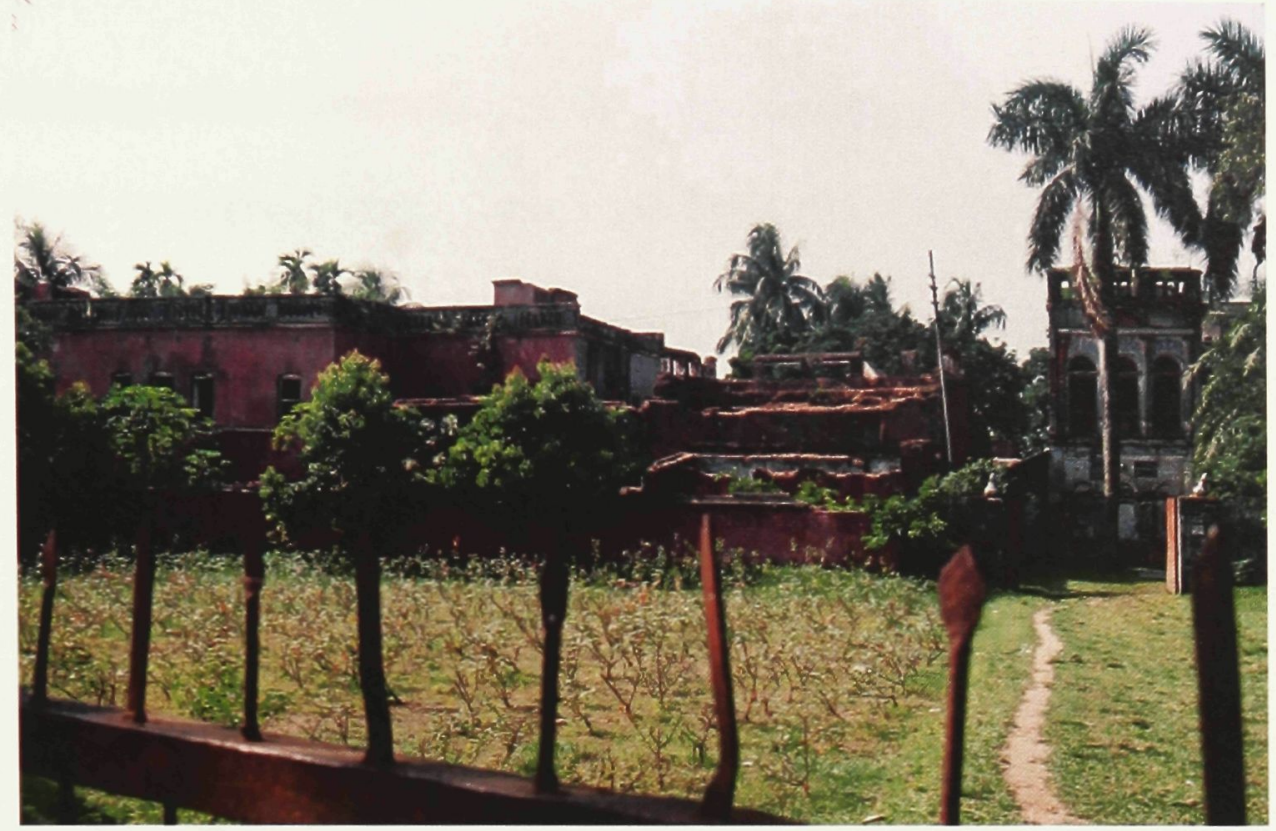

Ananda Mohan Poddar's house, an example of the compound houses

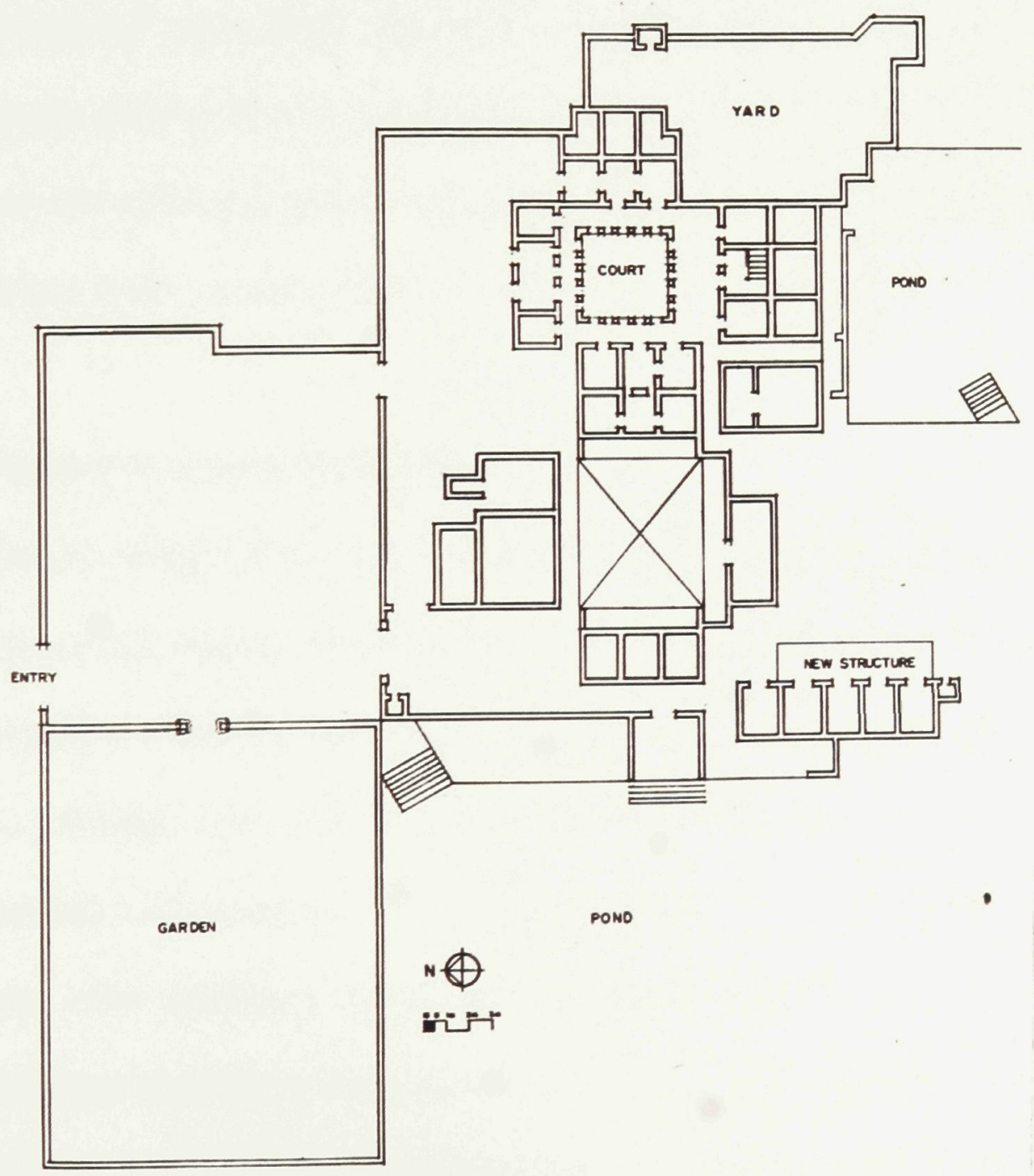

Fig 7: Plan of Ananda Mohan Poddar's house

Source: Archaeology Department, Bangladesh Government 
Among other examples of compound houses in Sonargaon, the 'Chota Sardar Bari' is located further south of the 'Bara Sardar Bari'. This is a relatively new structure still in use. The Hashimoy Shen's and the Bhanu Babu's houses are located on the north of Panam across the Pankhiraj River. Both the building complexes are hidden within dense foliage.

Many temporary structures have been built later within the complex, primarily for accommodation purposes. In the Hashimoy Shen's building complex, five old structures have been identified, out of which four are two-storied and one is single-storied. Ruins of two older structures, presumably from the Mughal period, are still surviving within the complex and the remains of two structures also exist at two ends, on the east and west.

\section{Pattern 2: Street Front Houses}

Panam Nagar is the most prominent early example of Street Front Houses in a non-urban setting. Located about 550 meters from the Folk Art Museum, Panam Nagar is a unique township in Sonargaon stretched along a single road $5 \mathrm{~m}$ wide on average and $600 \mathrm{~m}$ in length. The road extends from the west to east, slightly turning north-east after the half-way point. The road moves with delicate curves that offer changing vistas of the street facade. The road is linked with the Dulalpur road by a humped bridge at the west, and the Thana road on the east. The area is isolated by the Pankhiraj River running almost parallel to the road on 
the north and a moat, the Pankhiraj canal, that separates the land from the west and south. Fifty two houses, in a dilapidated and disused condition, of the settlement have been identified by the Archaeology Department of the Government of Bangladesh. At present, 31 houses are surviving on the north side of the road and 21 houses on the south. The area is densely built with single to three storied attached and detached houses of varying types and sizes. Only eight single story houses have been identified. The majority of the houses are two storied. Large houses are partially three storied. An exact count of the buildings according to the number of floors could not be done due to poor accessibility and the precarious condition of structures. 


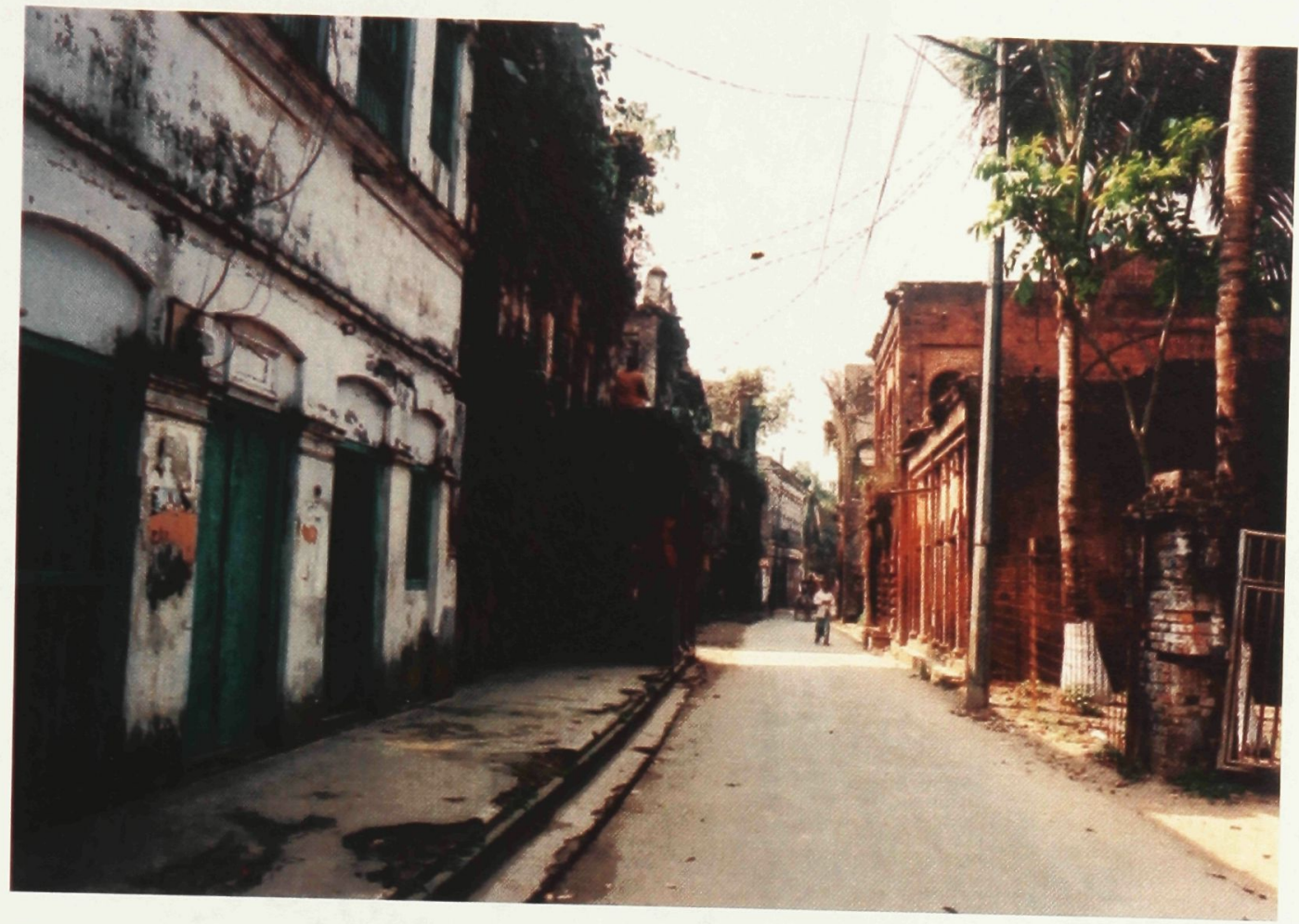

The street facing houses standing on both sides of the spinal street of Panam Nagar.

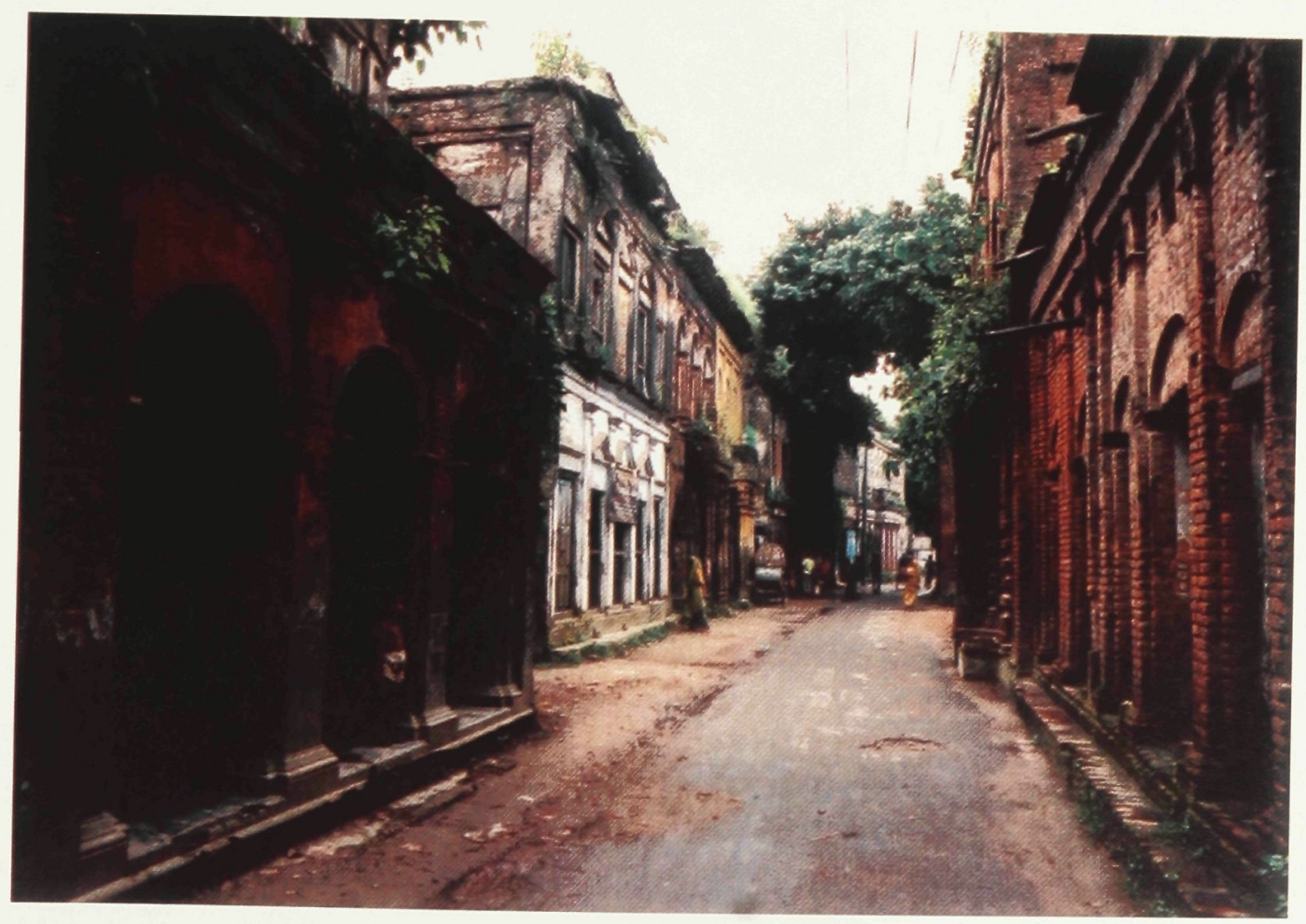

Another view, a little further on. Even in its ruins, it expresses its architectural ambience. 


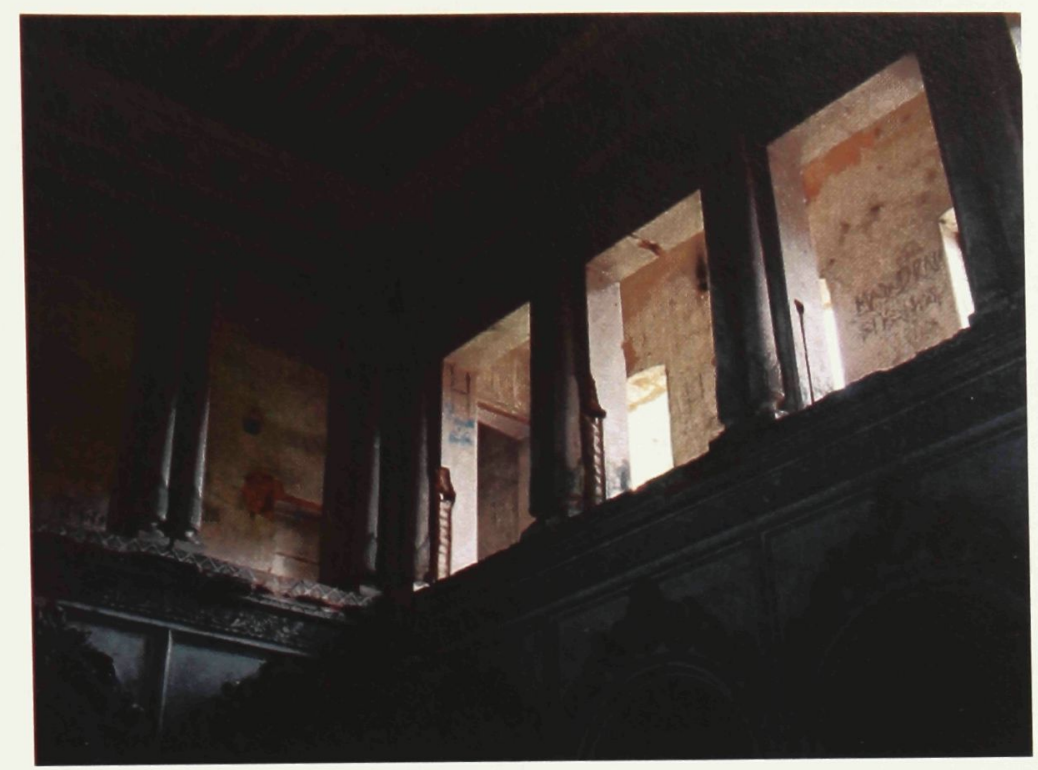

Interior view of central hall of building No.3

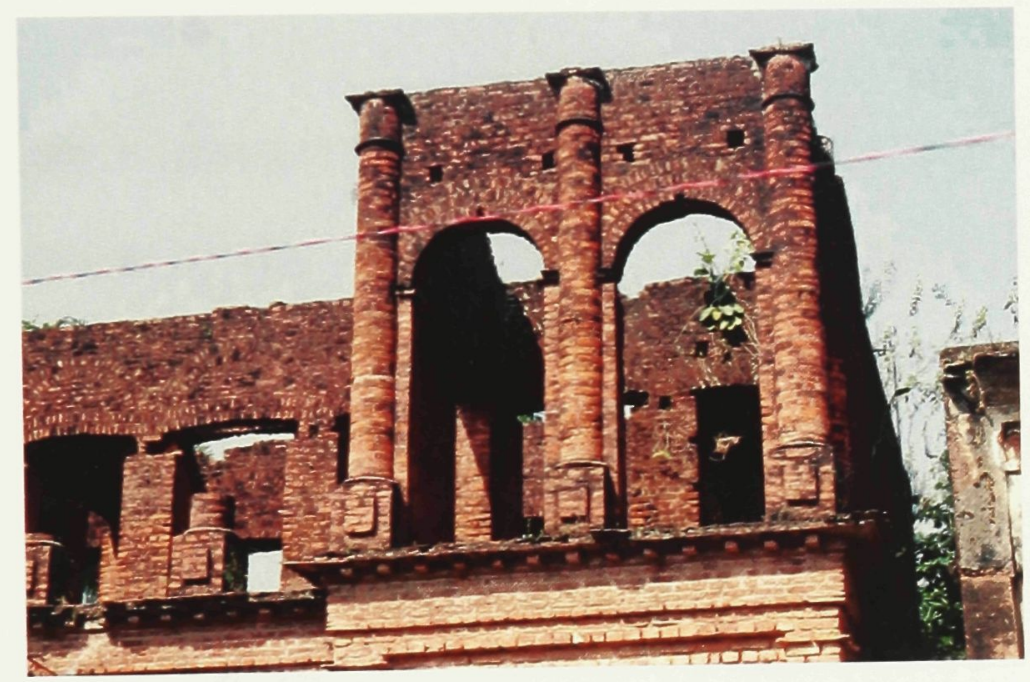

Building sculpted in brick, Panam

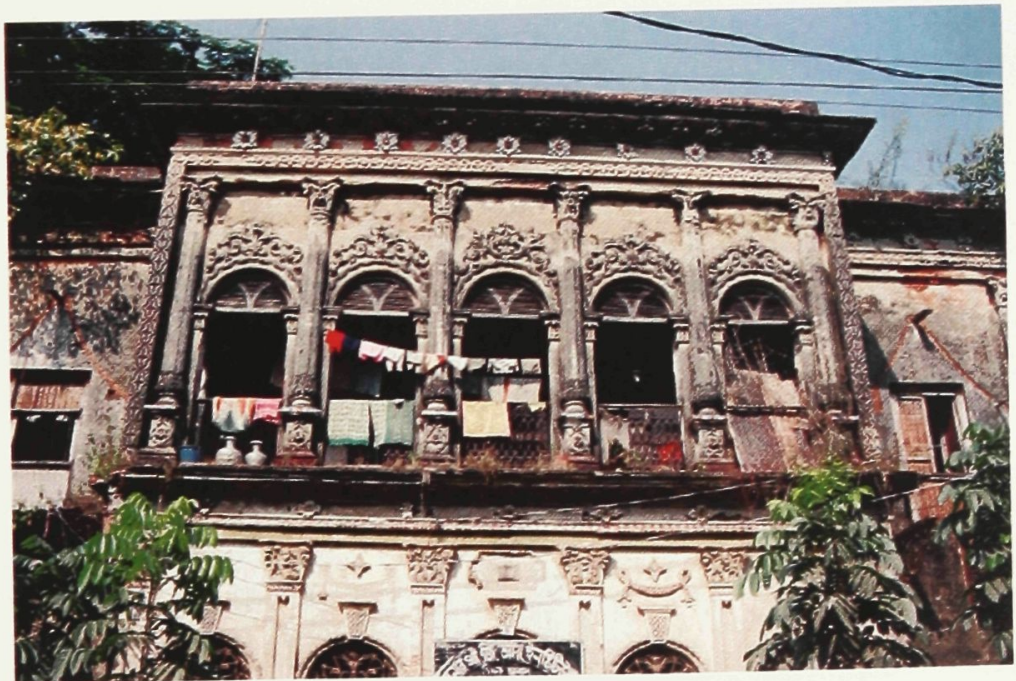

Buiding no. 26, popularly known as the Boarding House 
Comparing the accounts given by Taylor and J. Wise with a difference of 32 years, it is evident that the years after 1840 was a period of decline, and the years following 1872 was a period of reincarnation for Panam. The surviving buildings of Panam also date back to the late 19th and early 20th century. Plaques have been found in three buildings of Panam, indicating their dates of construction, with building no. 11 built around 1813 A.D., building no. 38 , known as 'Kashinath House' in 1898 A.D. and building no. 42, in 1928 A.D.

Only a general description of the existing condition of Panam is available in a number of history and archaeology books. Although several studies have been conducted on Sonargaon, Panam did not receive much attention in those works.

Presently, Panam, as a historical property, is under the ownership of the Government of Bangladesh. The Directorate of Archaeology is its custodian. Ownership of some houses is claimed by sign boards with the name of owner in front of the buildings, but the nature of ownership is unknown. Most of the inhabitants in Panam are unauthorized occupants. The exodus of original owners, the Hindu merchants, began with the partition of India. They felt insecure due to their minority position and were intimidated by subsequent riots. Present unauthorized occupants are too poor to maintain these properties and do not have any incentives to do so. 
The existing population of Panam is around 250, with a mixed population of Hindus and Muslims. Some of the staff of the Folk Art Museum and the G. R. School reside in Panam. The G. R. School, established by two brothers, Gangabashi and Ramcharan, in 1894, is located at the eastern end of the Panam Road. There is an art gallery in Panam in building no. 36. Building no. 26 is now being used as a boarding house and building no. 5 was previously used by the Archaeology Department as a museum. A new tin-shed structure was built in 1979 in the plot next to building no. 3 by "Sonargaon Juba Sangha" - the youth club. A new Durga temple, having a simple rectangular 'Puja Ghar', has been built opposite to building no. 42 .

The pattern of physical organization, as indicated by the C.S. Map of Mouza Panam Dulalpur and Thana Baidder Bazar, shows extremely elongated plot divisions with narrow street frontage. The building facades follow the curve of the road. While the buildings are placed at one extreme end of the road front, the toilets are placed on the other end on the water front. Water from the river and the moat is used for sanitation purposes. Four large ponds exist in Panam. All are located on the south of the Panam road. The ponds are placed almost at regular intervals from one another. Two of the ponds on the eastern side locally known as G.R. pond and Awal Saheber pond respectively, are linked directly with the moat on the south. The other two ponds known as Karai Poddar's pond and Bittahin pond are self-contained in nature. All the ponds are provided with more 
than one ghat or have a stepped approach to water. Also the ponds are used for bathing. Adjoining dressing rooms have been built near to the ponds. The existence of old pipe lines suggests that there may have been bathing facilities inside some of the houses. The drinking water is also supplied by wells. Thirteen such wells have been identified in Panam in the government survey. All of these wells are located at the backyards of the plots, except in one example next to building no. 26 , where the well is placed in the front, close to the road.

The buildings are mostly elongated in a north-south direction. Designs of buildings do not follow a regular pattern, but are a mixture of different typologies.

\subsubsection{Architectural Ambience of Panam}

In its present state of disuse and dilapidation, one can still feel the vibrant life of Panam history. A subtle competition to glorify the houses as an expression of self-image among the owners is apparent. In other words, each owner is presenting a facade to Panam Street in order to enrich the visual symphony of the ensemble, with each building keeping its own identity and also blending with the harmonious whole. The buildings followed a pattern language by which unity had been achieved with the use of two to three-storey heights, axiality, symmetry and arched openings. On the other hand, variety had been achieved through the introduction of verandahs, balconies, loggias and porches. The crowning of the 
buildings with decorative parapets and projected cornices interlock the structures with the sky.

\subsubsection{Material and Construction}

Brick: Brick is the prime construction material of Panam. It has been used in different shapes- rounded, angular, arched, pointed semi-circular, curvilinearaccording to the need of surface articulation. Bricks are either plastered or left exposed for facade delineation. In the arches, angular brick masonry has been used for structural reasons. In some of the structures, patterned brick-settings are seen on arches and bases of domes. The thickness of brick masonry walls varies from 50 to $70 \mathrm{~cm}$. Lime mortar has been used primarily for bonding.

The roof: The roofs are made of lime concrete slabs supported by wooden rafters and purlins in most cases. Occasionally, I-beams are used to support the roof. Brick vaulted roofs can be seen in case of the smaller rooms.

Ornamentation: Plaster decoration has been extensively applied in facade design and interior decoration. In some of the buildings exquisite surface decoration with carved bricks containing excellent indigenous motifs is seen. False wooden doors and windows shaped with plaster were also applied as a common decorative element. Stone quoins have also been copied in brick and plaster. 
Cast iron brackets, ventilators, window grills, balusters have also been extensively used. Decoration with broken china, locally known as 'chinitikri' work, was very popular in interior decoration and modest exterior application is also found in some examples. 

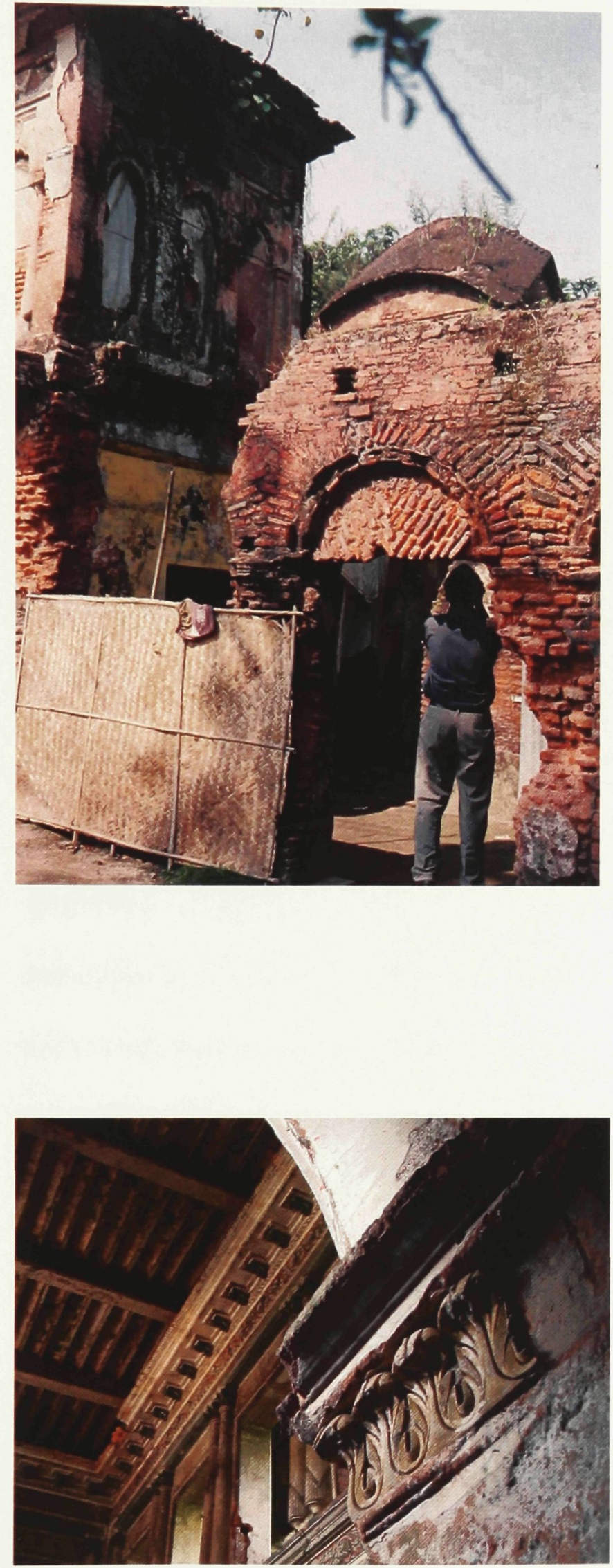

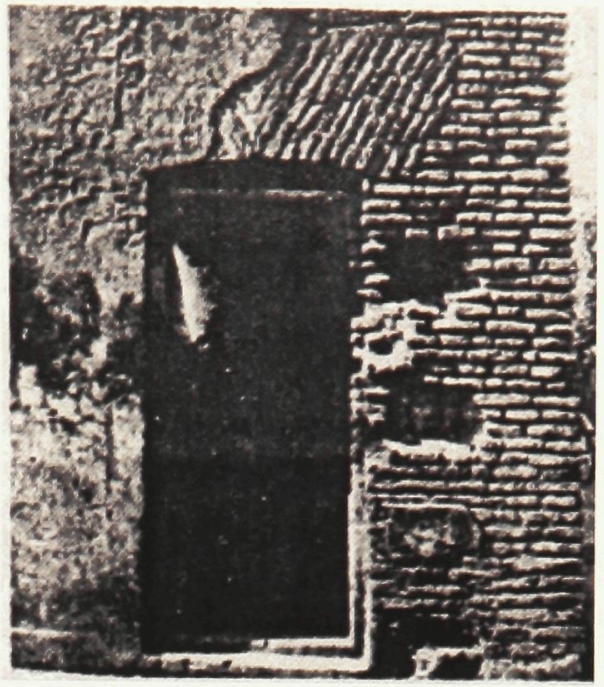

Brick is the principal construction material in Panam. Variation in the brick laying is noticeable.
Some of the detail ornamentation from Muslim period. 


\subsubsection{Formal Order of Buildings}

The buildings are mostly rectangular in shape. Therefore, the depth is greater than frontage in most houses. The width of the building facades vary widely, with the smallest being building no. 8 , which is only $3.5 \mathrm{~m}$. The largest include both building nos. 5 and 26 , since they are around $15 \mathrm{~m}$. wide. Average facade width varies between $6 \mathrm{~m}$ to $9 \mathrm{~m}$. The facades of all buildings are axially balanced with three, five, seven and nine openings. However, the axiality is not followed in the internal organization of the spaces. Openings are made with different kinds of arches with pilasters in between. All the pilasters have a defined base, shaft and capital. The floor levels are expressed externally with projected cornices. Also the parapets followed a uniform design and had heights with vertical slit openings, rounded at the top and bottom. Decorative elements have been extensively applied in the space between the arch and ceiling. The edge of the end walls were defined with special decorative treatment. Compared to the front façade, the side and rear walls and openings are left relatively plain without any articulation. This is clearly evident in building nos. 1, 26 and 40. However, the surrounding walls and openings of the inner courts and hall rooms were profusely delineated. The individual rooms in the dwellings were simply plastered with lamp niches in deferent locations. In addition, raised plinths and verandahs created the transition space between the inner house and the street. 


\subsubsection{Building Typology}

According to the building layout design, the dwelling houses of Panam can be classified into three basic typologies:

i) Central Hall type

ii) Central Courtyard type

iii) Consolidated type

\section{Central Hall Type:}

The design of central hall type was generated from a covered double height hall room as the main focus of the plan. However, the central hall does not represent the physical center of the plan, but the conceptual center from which the rest of the plan originates. Primary examples include building nos. 1, 2, 5, 16 and 26. The location, size and orientation of the central hall vary from building to building. In building nos. 2 and 5, the halls are located on the first floor, but in all other examples the halls are on the ground floor. The shapes of all the halls are rectangular, but the size varies. In building no. 5 , the hall extends along the entire width of the building, and the dimensions are $15.25 \mathrm{~m}$ in length and 10.36in. in width. The dimensions of the central hall in building no. 1 are $6.42 \mathrm{~m}$ in width and $10.65 \mathrm{~m}$ in length; in building no. 26 the length is $7 \mathrm{~m}$ and the width is $6.5 \mathrm{~m} \mathrm{In}$ building no. 1 and 16, the orientation of the longer axis of the halls is in a northsouth direction, while the longer axis of buildings nos. 5 and 26 are extended east-west. The central halls, 


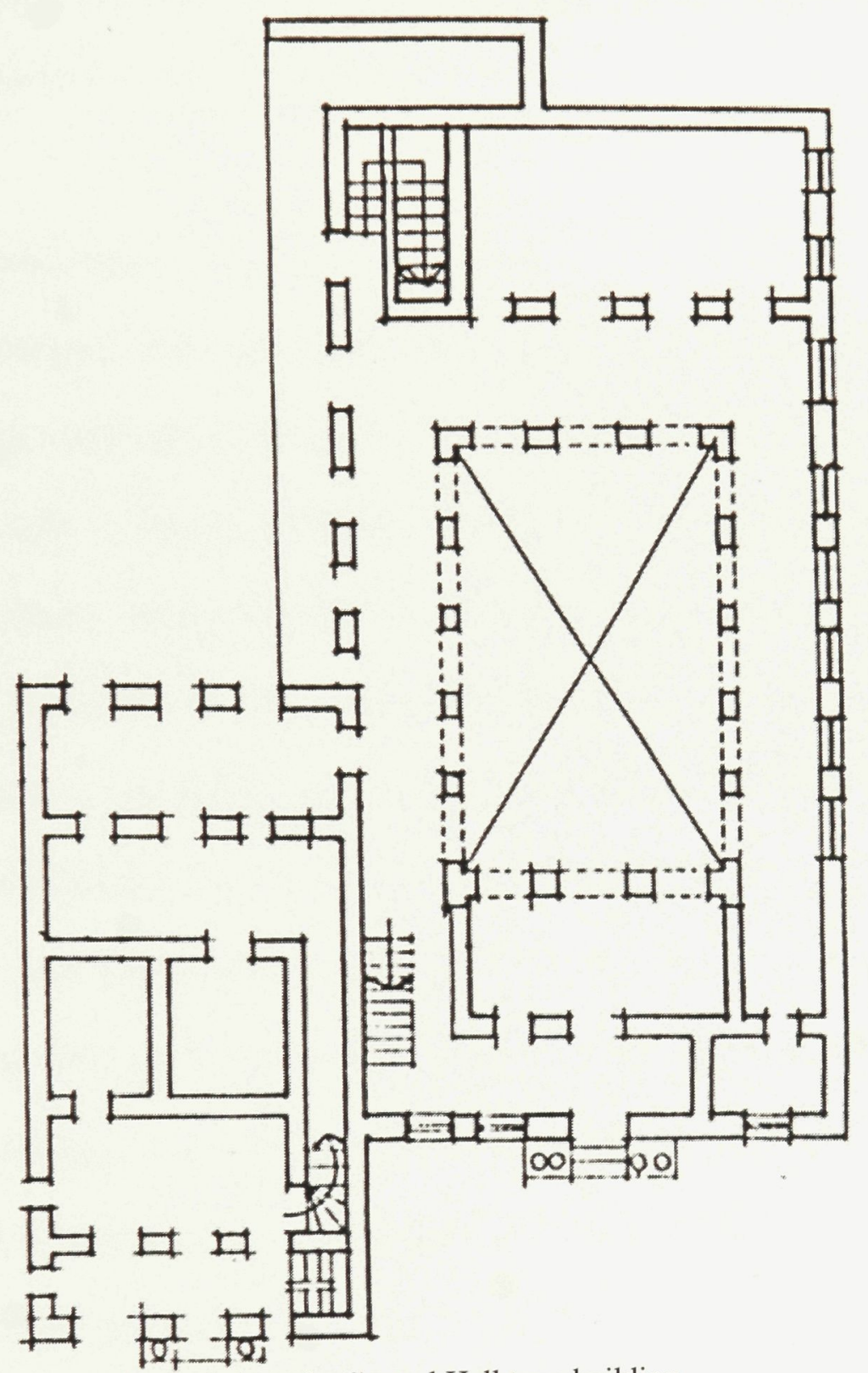

Fig 8: Typical plan of a Central Hall type building

Source: Archaeology Department, Bangladesh Government 
as the nerve centre of the houses, were highly romanticized with extensive decorations. These are the most expensive part of the house, expressing the wealth and power of the owner-occupier.

\section{Central Courtyard Type:}

This type is derived from the traditional rural house form centering on a courtyard. In this case also, the central courtyard does not refer to the physical centre of the house; it means that the building activities and layout are arranged around the courtyard. The courtyards are essentially enclosed, paved and open to sky and the inner house overlooks the courtyard. In general, the courtyards are surrounded by a verandah on all sides that has arched openings, except in those cases like house no. 38 , where one end of the court is lined with the boundary wall. The surrounding verandah acts as corridor and gives access to individual rooms. The enclosing walls of the courtyard are extensively delineated with arched openings and pilasters having ornamentation in the base, shaft, capital, cornice and parapet. It appears that almost similar emphasis was given to the design of the street and courtyard facades. The building no. 36 , where the Sonargaon Art Gallery is housed at present, is a mature example of the courtyard type house, which is still maintained in decent order. 


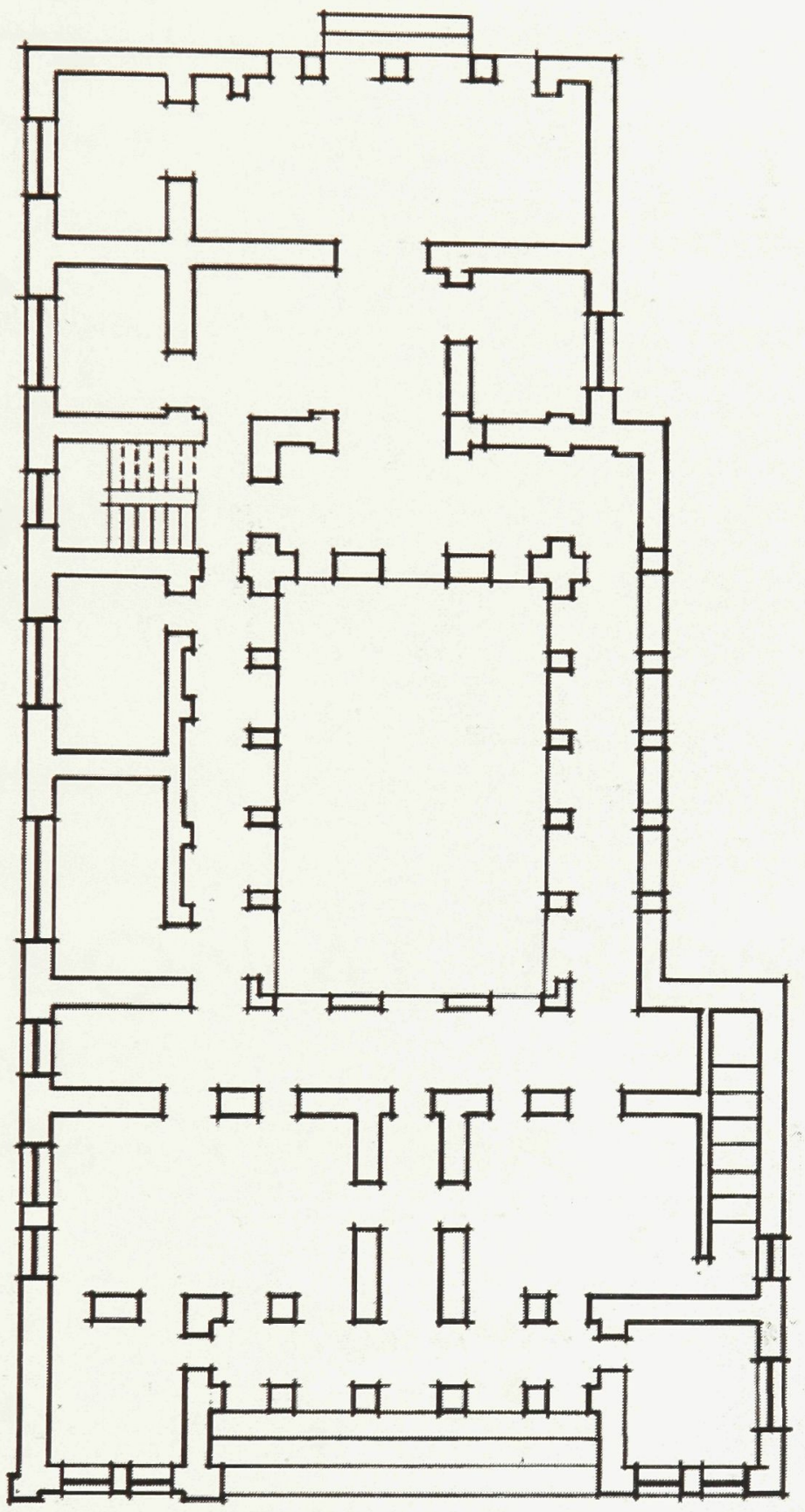

Fig 9: Typical Central Courtyard type building

Source: Archaeology Department, Bangladesh Government 


\section{Consolidated Type:}

This typology refers to those houses without any inner court or hall. The majority of houses in Panam are of this typology. The consolidated types are designed with either an entrance portal or a verandah or a high plinth as transition space from the street to the inner house. No uniformity is found in the organization of inner cells and rooms. The formal balance has been maintained in all the front facades that are unrelated to the inner organization of the houses. Single-storied buildings in Panam mostly belong to this consolidated typology.

Some of the unique designs, elements and special features in Panam are worth mentioning here. Considerable variation has been found in the roof-top designs. Building no. 9 has a roof top pavilion standing on round columns with a welldesigned base and capital. House no. 14 has a corner tower topped with a dome on the south-east corner, visible from the road.

In houses no. 30 and 31 , iron pillars have been used to support the projected verandah structure and verandah roof. Building nos. 25 and 42 are provided with small temple like structure on the roof top. The structures have a hut-shaped curved roof with a finial at the centre point. Both structures are designed with three arched openings in the facade. Building nos. 39 and 41 are also unique in character for their relatively smaller size and the uniformity of their decorative 
treatment on all four sides. A flight of steps or 'ghat' extends directly from building no. 39 into the

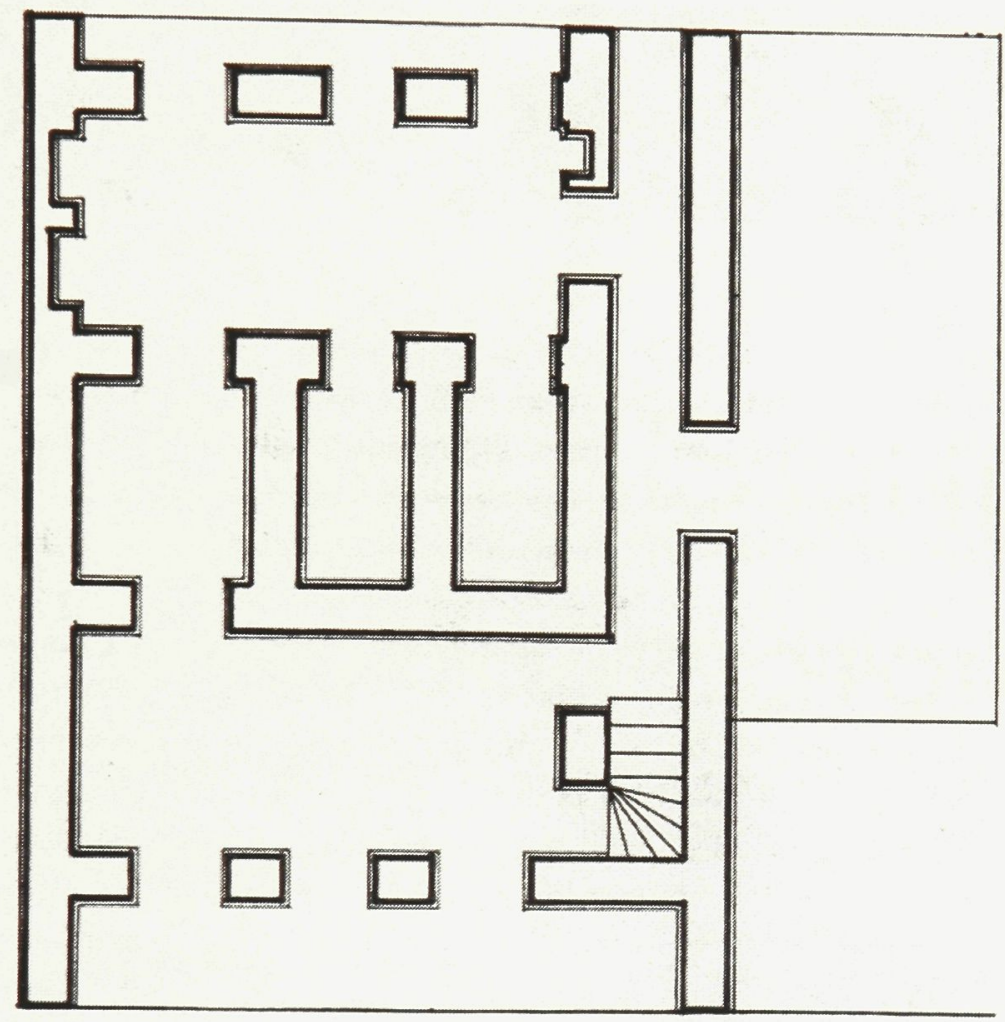

Fig 10: Typical Consolidated type building

Source: Archaeology Department, Bangladesh Government

G.R. Pond. Although the two structures are now being used for residential accommodations their original purpose may have been different. The very location, next to the pond, and the smaller size of the structures suggest that their purpose could have been related to the rituals of bathing, changing and dressing. 


\subsection{Other Monuments of Sonargaon}

Other important monuments of non-residential use that belong to the colonial phase have been identified in that Sonargaon area. Those include 'Krori Bari' and 'Neel Kuthi', located close to Panam and the Mograpara Land Office in Damdama.

\section{Krori Bari}

This monument is located on the north-east side of Panam. Originally, it was built on the bank of the Pankhiraj river, but the river has shifted further away. The purpose of the building was to serve as a treasury house for local merchants. 'Krori Bari' was a complex of three structures. The approach was from the east adjacent to the gate house. A two-storied small structure, presumably the office, was built on the south with a main treasury building on the west. The main building is an imposing two-storied structure, now completely in ruin. With years of neglect, the trees and roots have overtaken the building. As stated earlier, the decorative treatment of the building suggests that it belongs to the Mughal period. 


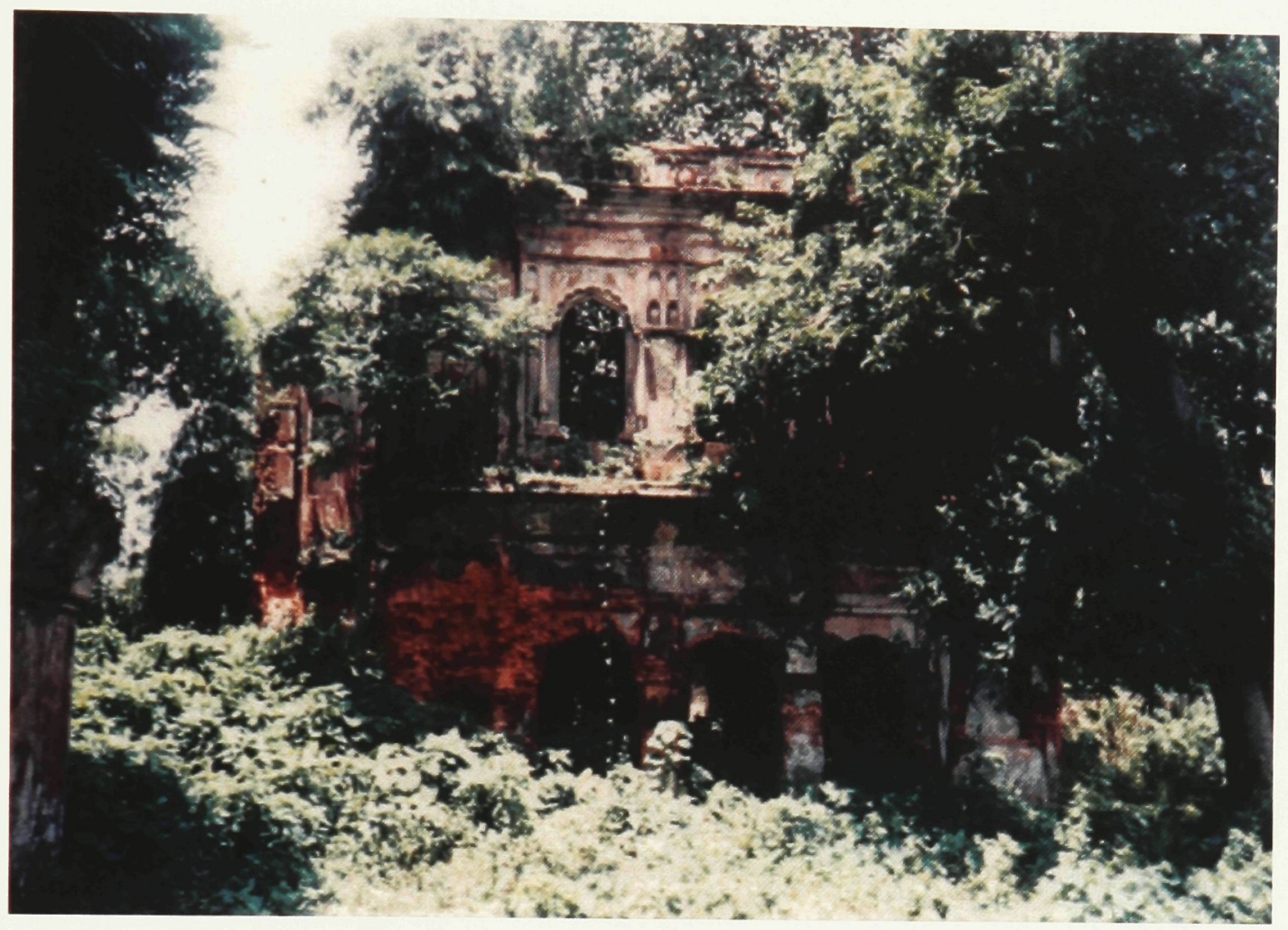

Krori Bari 


\section{Neel Kuthi}

This monument was built by the British in the colonial era for the purposes of the indigo trade and management. The building is located further north of Panam accross the Mughal bridge on Dulalpur Road. 'Neel Kuthi' is a large isolated structure built at a safe distance from the prevailing neighbourhood of locals. The building starts right from the edge of the road, and is separated by a high plinth. It has a flat front facade with regular arched recesses for window and door openings. In the layout design, it follows the courtyard typology. The courtyard, perhaps was used for the packaging and processing of Indigo powder, while the surrounding rooms were used for storage. Also the front building may have been used as office. The rear of the building is completely fortified with blank wall surfaces and the main entry is located on the road with a side entry located on the middle of the north wall next to the stairs toward the upper floor.

Although 'Neel Kuthi' is a two-storied structure, an upper floor is provided with a mezzanine for storage purpose. The extended portion of the mezzanine floor is visible on the front facade as blank wall panels. Also a combination of Mughal and local decorative features have been applied in the building. 


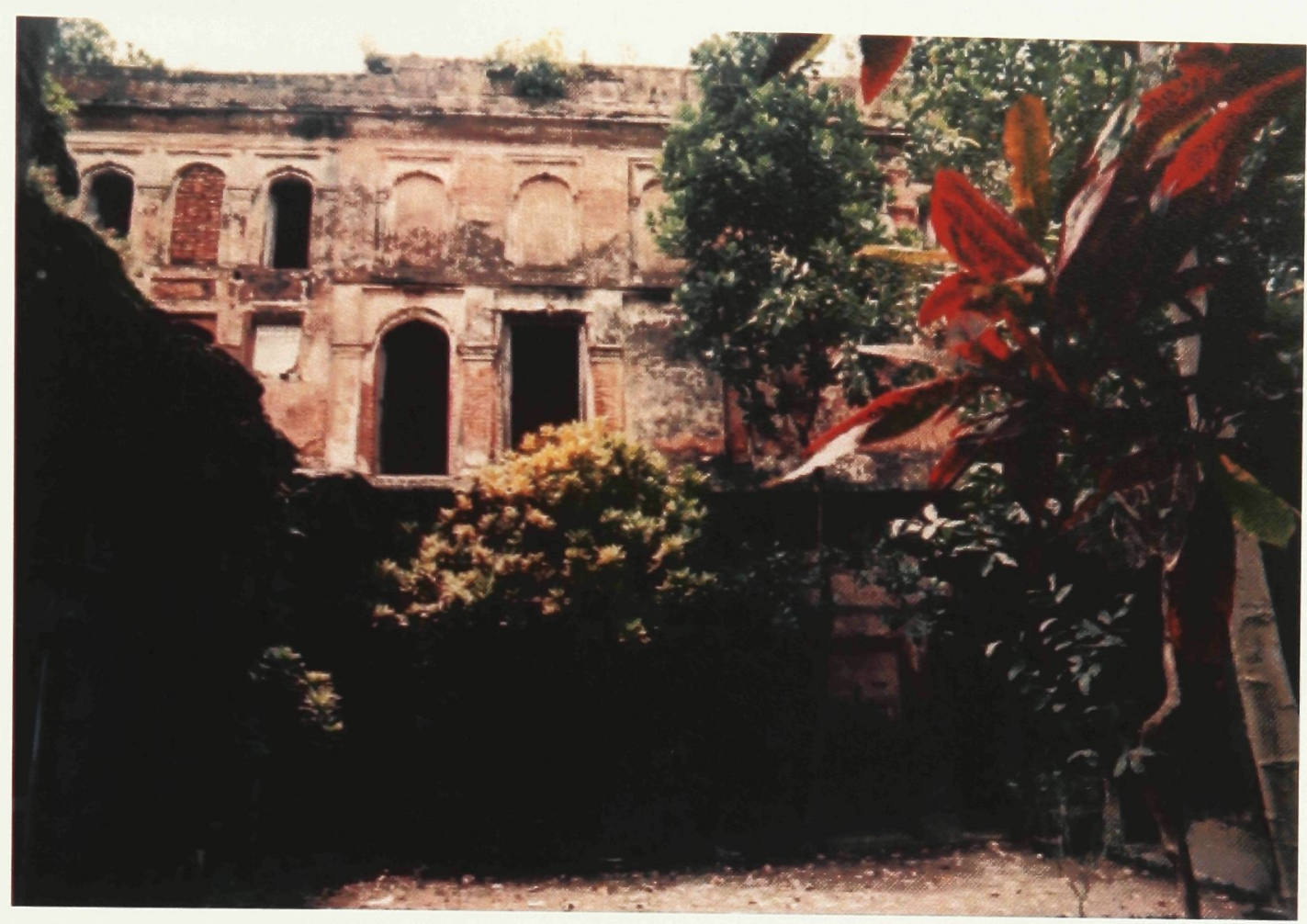

Neel kuthi

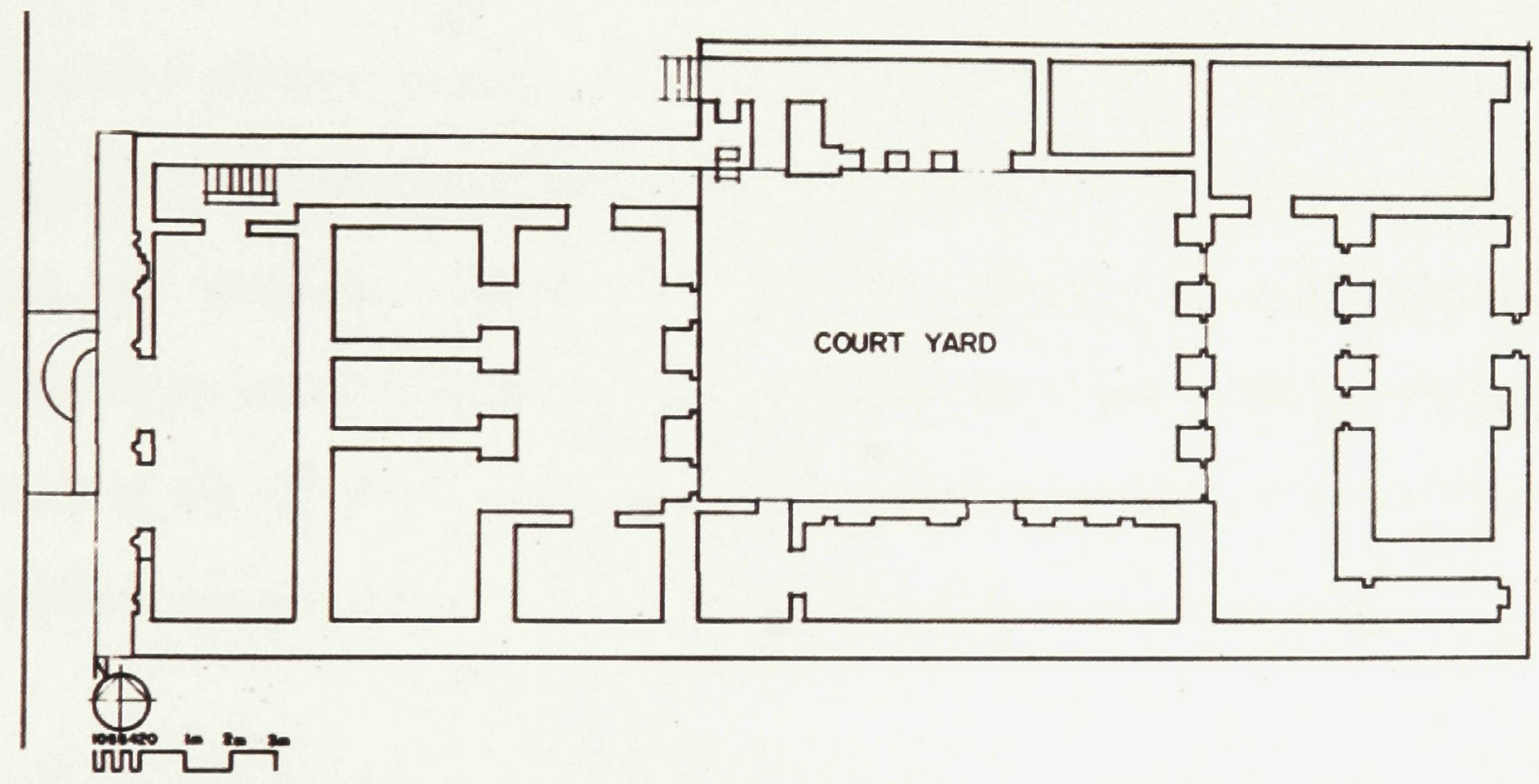

Fig 11: Plan of Neel kuthi

Source: Archaeology Department, Bangladesh Government 


\section{Mograpara Land Office}

The land office is located in an old single-storied building. The building is unique in the area, isolated by location and architectural character. The structure is rectangular in shape, surrounded by a low-height verandah. This is the only building where a post and lintel construction system has been followed. The front facade is composed of seven bays, defined by pillars supporting the verandah lintel. A very wide flight of stairs covers three bays, curved at the two ends to give access to the plinth level of the verandah. The design of base, shaft and capital of the pillars follow the patterns of Hindu temple architecture. A cornice projected from the lower roof on the verandah runs all around and the verandah roof is decorated with a low parapet having alternate pointed and rounded projections at regular intervals. The corner points are terminated with dwarf minarets and the The main structure beyond the verandah is projected up. It has a shallow roof projection above which a perforated parapet is placed. Here, the corner points are also terminated with dwarf minars. To emphasize the main axis of the building the parapet above the central bay has been highly projected. A cup type motif at the tip of the projected parapet further emphasizes this centrality. In addition, a large open yard in the front provides full view of the building.

It is important to note that of all three examples mentioned above, 'Neel Kuthi' is the only example of a colonial building built by the British in Sonargaon. The rest were built in an improvised colonial pattern by the locals for their individual 
needs, expressing their 'acquired taste'. While the colonials were engaged in incorporating regional styles in their architectural work, the locals were tempted to follow the architectural traits imported by the British.

\footnotetext{
${ }^{1}$ Karim, Md. Razaul. SONARGAONER ITIHAS: Utsa O Upadan. Ed. Dr. Saikat Asghar. Dhaka, Bangladesh: Rahman Group of Industries, 1993. 115-122

${ }^{2}$ Hussain, A. B. M. Sonargaon - Panam: A Survey of Historical Monuments and Sites in Bangladesh. Ed. M. Harunur Rashid and Abdul Momin Chowdhury. Dhaka, Bangladesh: Asiatic Society of Bangladesh, 1997. 103-133
} 


\section{Chapter 5: Problems and proposals}

Like many other areas of Bangladesh, Sonargaon possesses a large number of monuments and sites of historic importance, which need to be conserved for larger socio-cultural and historical interests. At present, Sonargaon is under pressure for growth of new and unplanned development, which poses a tremendous threat by destroying the visual continuity and architectural integrity of this historic city. Therefore, it is necessary to take protective measures to preserve this area while, at the same time, considering appropriate measures to upgrade and readjust the present encroachment, with the essence of area conservation.

At present, Panam Nagar stands as a unique township stretched along a single road, $5 \mathrm{~m}$ wide on average and $600 \mathrm{~m}$ in length. Fifty brick houses, now in a dilapidated and disused condition, are arranged on both sides of this road in close proximity. There are more buildings scattered around the area, mostly in ruins. Many of these buildings are still in use, although they are no longer in useful condition. One of these buildings has been restored and converted to a folklore museum. But generally Panam has been left ignored. The buildings are slowly being engulfed by time and decay. Although Panam Nagar has been officially declared an archaeological site by the government, many of the buildings are still occupied by illegal owners. Therefore, there is little or no 
maintenance done in this area. Sonargaon is now growing as a township, and is soon to become a city, which is a potential threat for Panam Nagar. If the city is allowed to grow in this unplanned manner, it will soon destroy Panam.

With the death of Panam, the local tradition of crafts and trade has also died. In order to bring life back into Panam, the local trends have to be enlivened. The craftsmen have to be re-instated, and the trades resumed.

Finally, the place has to be designed to possess various tourist attractions. The proposal for conservation focuses on increased tourism in Panam. Already the folklore museum nearby is an important tourist attraction. In the Folklore Museum complex, a seasonal folk arts and crafts fair is organized, which attracts many people. Creating a similar situation in Panam city is very much possible with proper planning and initiative.

So there are multiple issues to be considered in the proposal to conserve Panam city.

- Identify cause and remedy of destruction

- Establish legal or government ownership

- Plan for growth of the city

- Protect local crafts

- Recreate scope for trade 
- Create tourist attractions

\subsection{Recommendations}

Restoring buildings to their old use or adapting them to a new use, so as to keep a whole area of the city alive, are practices which have existed as long as building and cities have existed. In the past, when the rate of change was slow, the sense of permanence was correspondingly high. So much so, that after its destruction in the Thirty Years' War, Dresden was completely rebuilt in the new Baroque style. ${ }^{1}$ There was no question of erecting replicas for any of the medieval buildings which had been destroyed.

It has been said truthfully that "it is rapidity of change which increases the psychological need for permanence." In Western Europe, since 1950 one can mention a greatly accelerated rate of change, impelled, on the one hand, by the destruction of the war and, on the other, by new technology engendered by the war. Phrases like "wholesale demolition" and "comprehensive re-development" were invented during this time when whole city quarters were giving way to the bulldozer. Already the war had caused the decline of that earlier sense of permanence and the consequent desire to recapture it. So much so, that after its destruction, Warsaw was rebuilt as a replica of what it had been. There was no 
question of erecting even a single modem building within the reconstructed walls of the old city.

The widespread destruction and renewal of old quarters, which have affected most of the major cities of the world, have made the world realize that the loss of the familiar can go too far. A second reason is the realization that the old buildings often do their job a better than new ones. It should perhaps be a condition for any demolition, that the new building must always be better than the old, which it is replacing.

In Bangladesh, one cannot afford to demolish buildings which still have plenty of life in them. This is not only because old buildings are usually more efficient in energy conservation than new ones, but also because the actual work of rehabilitation or conservation costs in energy terms are a mere fraction of new building. Lastly, there is the fact that rehabilitation is labor-intensive. It creates employment and keeps both the small and the large builder busy, whereas comprehensive redevelopment and tower blocks rely far more on factory-made parts and mechanical assembly, which only the few large builders can manage.

Adaptive re-use and historic preservation fall within the wider parameter of conservation. This refers to the act or process of preserving something in being, and of keeping something alive. And in keeping something alive, that something 
being in this case anything from a single building to a whole city block, it may be necessary to infuse new life.

So conservation does not exclude demolition or new construction. Therefore, it does not, in other words, exclude change. One might indeed take the argument further and say that, without the ability to change, a city would die. A conservation policy for a particular area must take into account wider planning issues. It must address itself not only to the problems of historic preservation, but also to new development and therefore to the problems of height and density, and of infrastructure. Indeed, it must also take into account social and economic factors.

The recommendations for the conservation of the Sonargaon site have been divided into three phases

PHASE ONE: POLICY

PHASE TWO: PLANNING

PHASE THREE: IMPLEMENTATION 


\subsection{Phase One: Policy Level}

The following policies are recommended in the preliminary phase of conservation.

- Demarcation of the boundary

- Identification and listing of historical monuments

- Classification of listed monuments.

- Justification for the conservation, preservation and restoration of the listed monuments

- Rules and regulations

- Participation of local people

\subsubsection{Demarcation of Boundary}

At the earliest stage of the policy level, it is important to establish and demarcate the boundary of the historic Sonargaon. This phase of work will help historians, architects, and other allied professionals, recommend and implement policies regarding area conservation of the Sonargaon site.

\subsubsection{Identification and listing of monuments}

Different structures and areas should be selected for conservation. This phase acts as the benchmark for the implementation of any conservation project. A list 
of buildings of historic importance, their protection and preservation have been done by the Department of Archaeology and Museum. But their principles are guided by century-old legislation introduced by John Marshall. ${ }^{2}$ However, this restricted policy can only identify different monuments and structures which are more than 100 years old for conservation or preservation. There are, however, a large number of historically significant structures scattered all over the Sonargaon area which have yet to attain the age 100 years, and may disappear before that stage is reached. These structures need to be identified and listed for conservation to sustain the history of this area, and to uphold the culture and heritage of the entire country.

Therefore, the primary function of Sonargaon conservation process is to list all the important monuments, after assessment with the following analytical inventories of architectural, historical, economic and socio-cultural aspects.

- Historical Background

- Period of construction

- Analysis of style and character

- Evaluation of existing physical condition.

- Need for addition and alteration

- Characteristics of details and decorations of building elements

- Construction methodology and system of the structure

- Potential for re-use 
Based on the present survey, a number of monuments, structures and sites have been listed.

\subsubsection{Classification of listed monuments}

The aim of the following classification is to identify and categorize different structures and areas recommended for conservation, restoration or preservation. These include:

- Religious Buildings (mosques, madrasas, temples etc.).

- Landmarks (gateways, bridges, tombs and forts).

- Secular buildings:
a. Isolated individual buildings, relatively small and detached structures.
b. Buildings in rows, roadside linear structures forming an integrated pattern of development.
c. Palatial large building complexes.

\subsubsection{Justification for conservation}

According to the classification mentioned above, the religious structures of Sonargaon like Bandar Shahi Mosque, Feath Shah's Mosque, Dewanbagh Mosque, Muazzampur Shahi Jami Mosque etc. require preservation or restoration to maintain the fabric of the structures in their original state, as well as to arrest further deterioration. Their functional use must also be retained. 
"Archaeological conservation postulates prolonging the life of a historic built form or environment, arresting all the human-made and natural elements causing decay and erosion." ${ }^{3}$ According to Sir John Marshall "... the object is not to reproduce what has been defaced or destroyed, but to save what is left from further injury and decay and to preserve it as an heirloom for posterity." 4 Any addition or alteration is prohibited in archaeological conservation unless those are required to save the monument from structural failure. Based on the above concept, all mosques, madrasas, mandirs, tombs of the Pre-Mughal, Mughal and Colonial periods shall be protected under archaeological conservation.

The Landmarks of Sonargaon like the Tomb of Sultan Ghiyasuddin Azam Shah, Panam Bridge, Sonakanda Fort, Panch Pir Mazar, Gateway and Naubatkhana of Dargabari and Mograpara also need to be protected. By restoration, it shall retain the existing fabric of the structures to an earlier known state by removing accretion or by reassembling existing components without the introduction of new materials. However, in case of reconstruction, it shall retain the structure as nearly as possible to a known earlier state with the introduction of new materials into the fabric.

The secular buildings of historical importance like Bara Sardar Bari, the house of Ananda Mohan Poddar's, Hashimoy Sen's, Bhanu Babu's, Krori Bari, Neel Kuthi and Panam Nagar need to be protected through architectural conservation to 
retain the unique cultural significance and heritage. Architectural conservation includes many aspects like maintenance, preservation, restoration, reconstruction or adaptation according to needs and circumstances without destroying the historic value. The basic advantage of this concept is adaptive reuse, i.e., preserving and maintaining old structures in modern, urban, economic and development contexts. Also, this specific concept does not stand for preserving individual building huts, but also maintaining the original character of the area as a whole. It does not freeze the original character, rather it can retain the original architectural environment, while also accommodating present demands and activities.

The following proposals have been developed for adaptive reuse of the above typologies. It offers a wide range of functional options for the conserved structures.

Typology

Large building complexes

(e.g.: Poddar House)
Probable Use

Museums / Libraries

Hotels / Restaurants

Schools / Colleges

Buildings with internal courtyards

Exhibition spaces / Galleries 
(e.g.: Boarding House)

Small row houses

(example: House No. 9, 14, 30, 31)
Motels / Rest Houses

Shop houses

Residential Accommodation

\subsubsection{Rules and regulations}

Area conservation should therefore be an integral part of town and country planning policy. In Bangladesh, however, there is no such policy or legislation for conservation, not even a passing reference.

Here, the East Bengal Building Construction Act. (EBBC) of 1952, the Paurashava Act. of 1977 and the Building Construction Regulation of 1984 are the only legislation applying to building and land use control. But none of this legislation includes any bylaws or passing references regarding conservation. Therefore, it is essential to establish regulations on conservation to protect the built culture of Bangladesh. These recommendations include:

- There should be a local authority who would be entitled to control land use development. This authority must be empowered to enforce different conservation laws and bylaws. 
- Specific design guidelines should be prepared for the Sonargaon area regarding building height, massing, setback, public health and safety; so that any new development would blend perfectly with its surroundings. Also, any new development, demolition or alteration would require prior permission from development authority. This authority should also be responsible to deliver repair and maintenance notices to the owners and occupiers of the listed buildings.

- But whatever different rules and regulations can be prepared, their implementation will be easier if there are adequate provisions of promotional and positive incentives like financial assistance in terms of grants, loans, public awareness and motivation.

\subsubsection{Participation of local people}

It is recommended that local authorities take the initiative to motivate the government and the local people to protect this area by upholding the special architectural and historical interest of Sonargaon and convincing them that the character of these structures is worth preserving and enhancing. A conservation program cannot be done without the willing cooperation, participation and acceptance of the local people. This cooperation is possible to attain if the aim of conservation can be communicated to the concerned residents and owners of the listed structures. It must be emphasized that conservation is not to 
dispossess property rights or to inhibit the economic use of properties within the controls imposed to guide preservation and conservation. The purpose of conservation at Panam is to inject life into it, and without public acceptance, this effort is in vain.

The objective is not to turn Panam into an object of display, but into a part of life. For that, new functions and programs have to be introduced, for example, a production zone, which will increase the population. Therefore a new housing area may be developed. At the same time, the few legal owners and those still related to crafts will continue to live in Panam, as they are part of the spirit of Panam.

No government or institution can successfully carry out any conservation project without the spontaneous support of the public. The key to success of any planning strategy depends largely on the approval and involvement of the public. Therefore, the objectives of motivation must be aimed at:

(a) Making the general public conscious of their heritage expressed through the historic environment and awakening an active interest in its cultural, social and economic importance.

(b) Making the public aware of its responsibilities in the process of conservation, preservation and maintenance. 


\subsection{Phase Two: Planning Level}

A major part of this thesis evolves around this phase. The study and research work done on the Panam Nagar site is the basis for constructing this part. This phase involves planning for conservation of the overall area and individual buildings. The following functions are needed for the implementation of the planning phase:

- Preparation of a Master Plan for conservation

- Causes and probable solutions of deterioration 


\subsubsection{Preparation of a master plan for conservation}

In this phase of action a map must be prepared to illustrate where the listed monuments and structures are located with the major routes connecting the different monuments and structures. This map shall be articulated with the following items

\section{Conservation Area:}

The immediate surroundings of the listed buildings and monuments of archaeological and historical importance are designated as conservation area. These areas must be protected with priority and must follow the design controls and guidelines.

\section{Design zones:}

The areas where new development is permitted although keeping the original character must be considered as design zones. Regulations of height, color, material, texture, distance and function are to be imposed on new developments to match with the old. The master plan will broadly have the following zones:

1. Small scale industrial area for production of handicrafts

2. Showrooms and display areas (converted individual houses)

3. Libraries and Museums (converted compound houses)

4. Residential zone for the craft people 


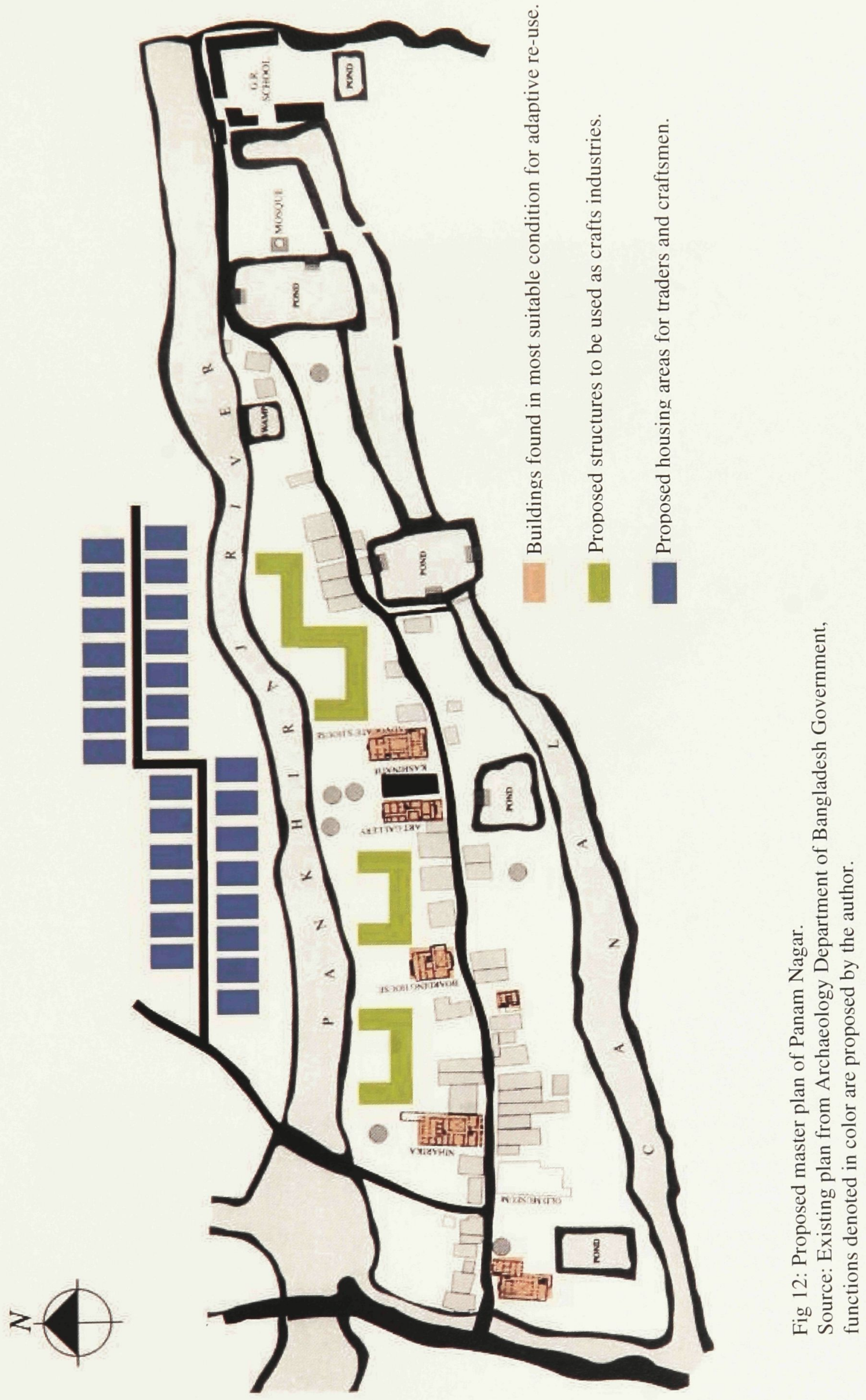




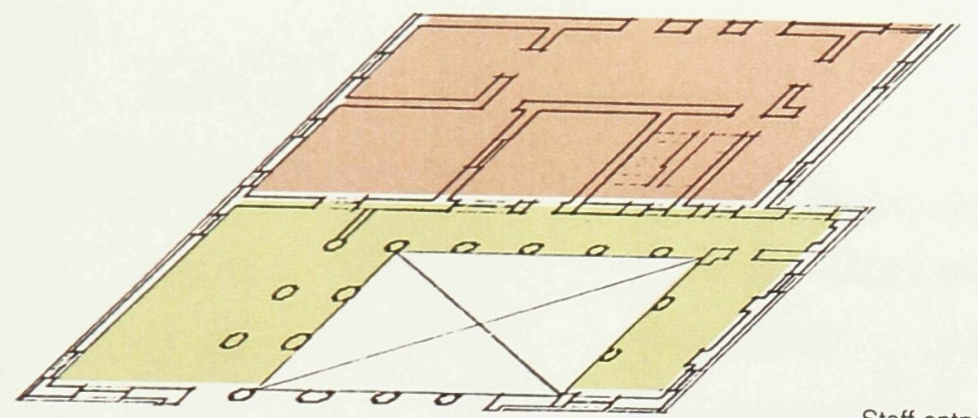

Staff entry

First floor

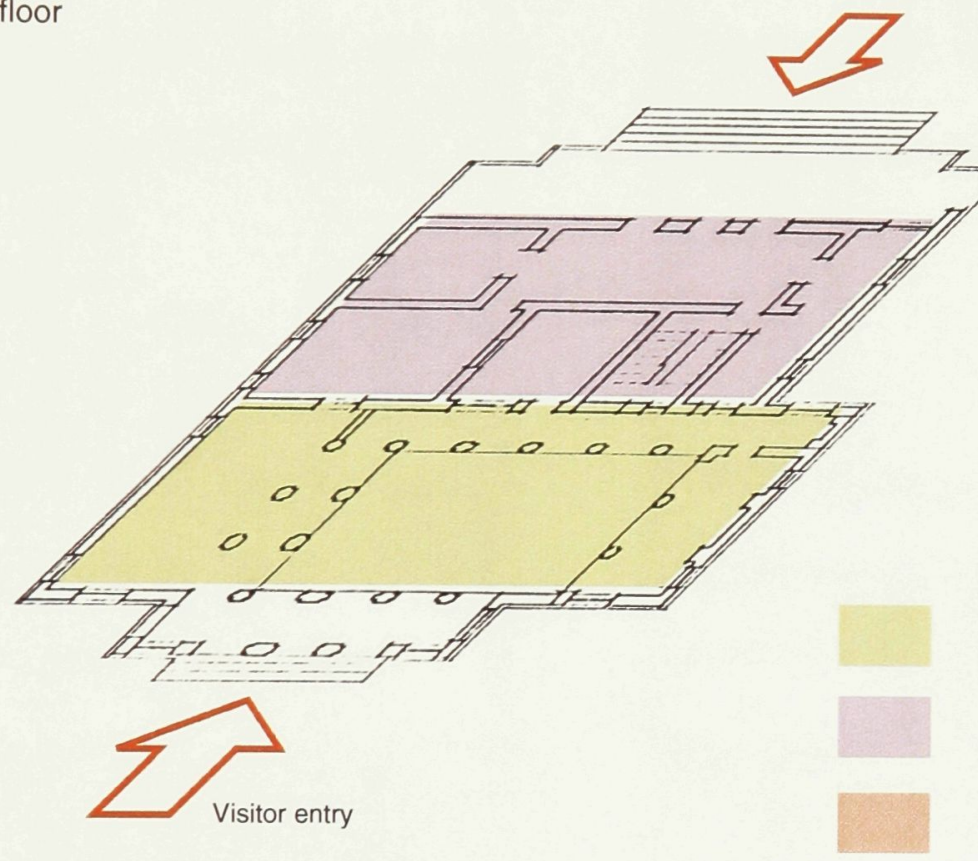

Public / Display area

Administrative area / Living area

Private area / Bed rooms

Ground floor

Fig 13: Proposal for building no. 16 to be converted into a Shop House. The ground floor is to be used as display and public area, and the first floor is private area.

Source: Existing building plan from Archaeology Department of Bangladesh Government, internal program proposed by the author. 

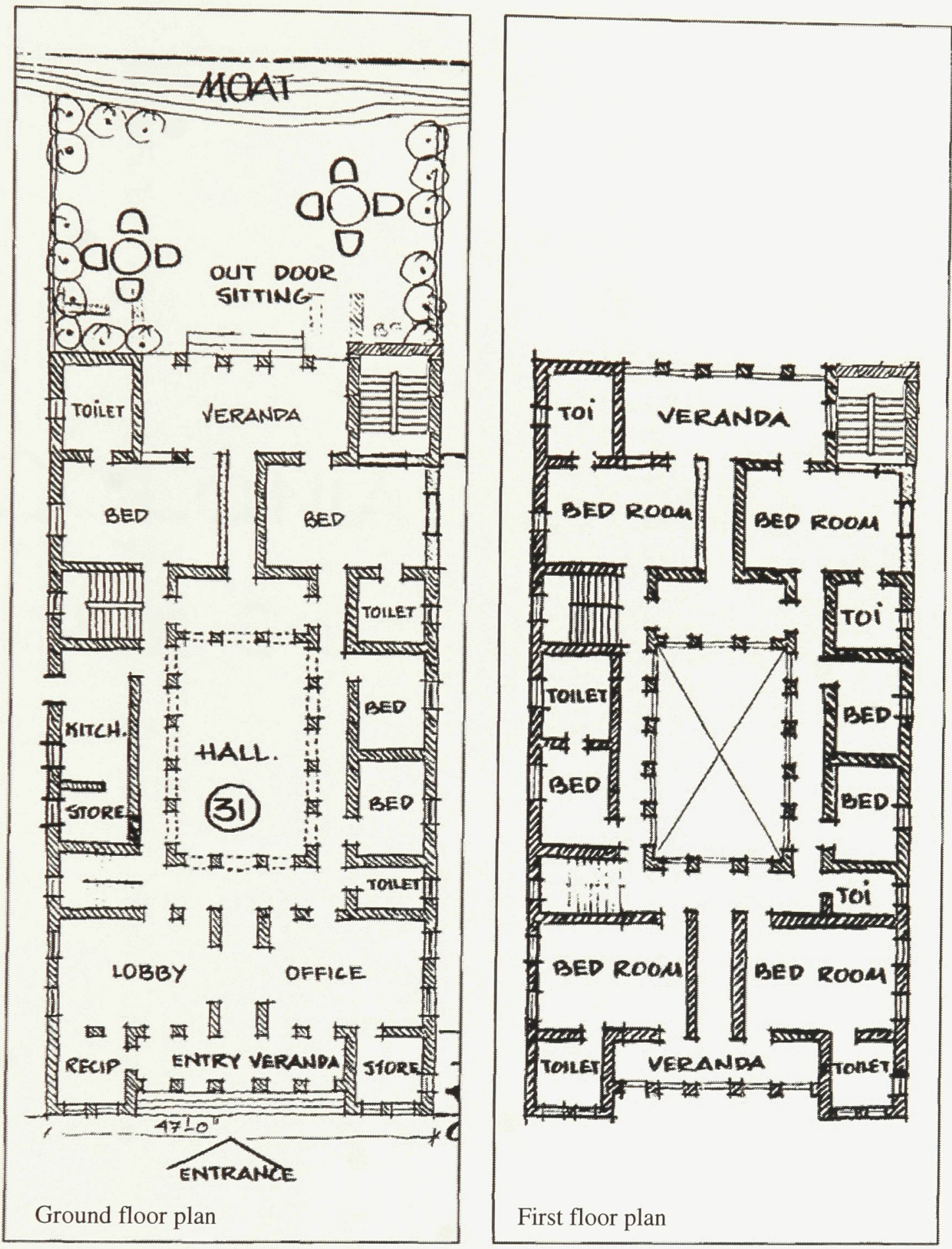

Fig 14: Proposal for building no. 26, popularly known as the "Boarding House", to be converted to a rest house or a motel.

Source: Existing building plan from Archaeology Department of Bangladesh Government, program proposed by the author. 


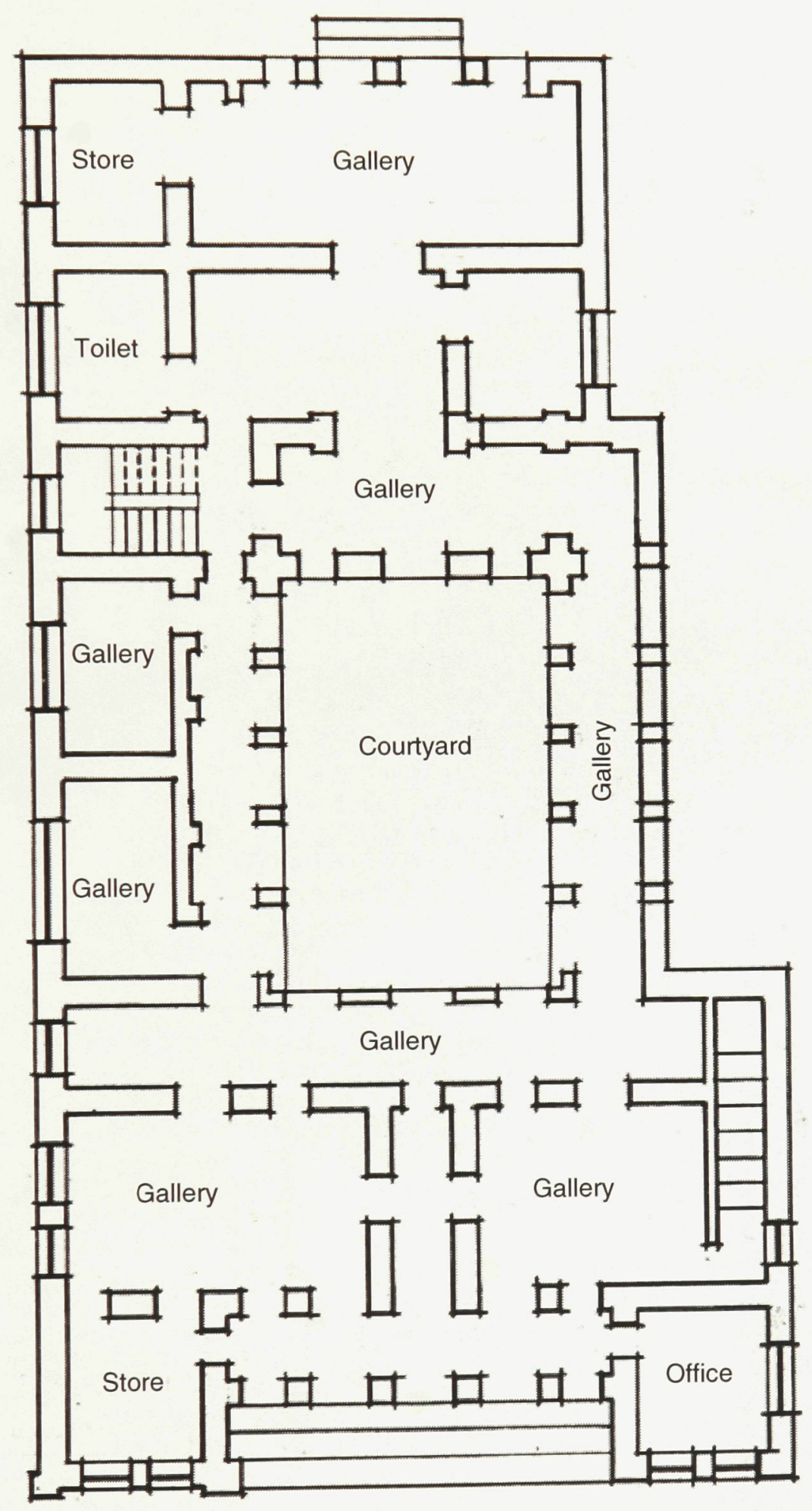

Fig 15: Proposal for building no. 38 (Kashinath House) - with a central courtyard - to be converted to a museum.

Source: Existing building plan from Archaeology Department of Bangladesh Government, program proposed by the author. 


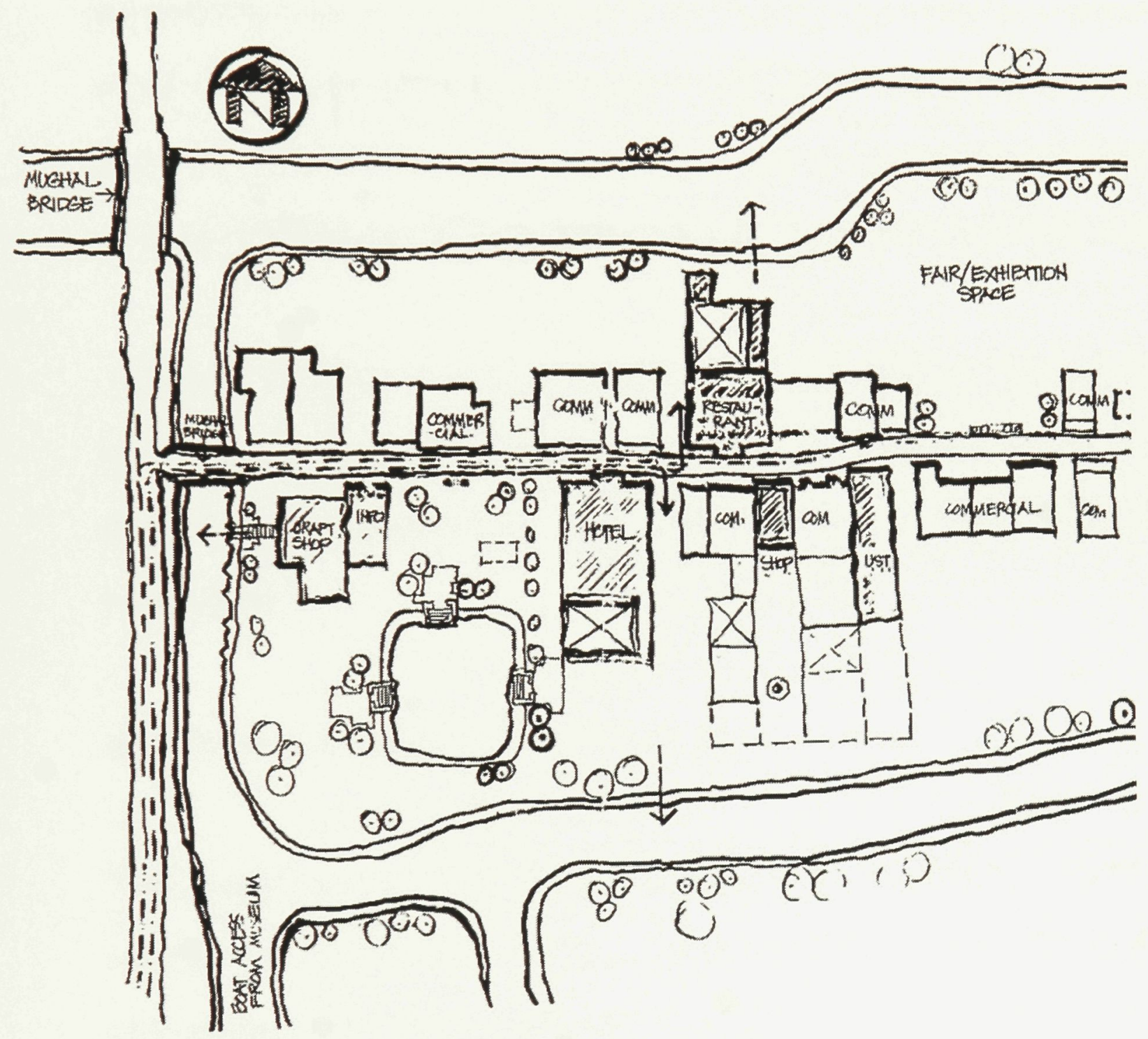

Fig 16: The buildings with the potential for most rapid cost recovery are to be done first including a craft shop, a restaurant, an information centre and an outdoor seating area.

Source: Drawing prepared by the author 


\section{Controlled Surrounding Area:}

The areas beyond the conservation area can be identified as controlled surrounding area. This area consists of buildings and townscapes where different built forms and the street facades may or may not harmonize with the structures and built forms of the conservation areas. Future development of those areas must be controlled according to the needs and demands of conservation area.

However, some places are still remote and unapproachable. The purpose of a new master plan of the conserved areas should be developed with a view to provide better accessibility and interconnection between the different monuments.

\subsubsection{Causes and probable solutions of deterioration}

The present condition of the building materials for the listed monuments and structures of Sonargaon is not very satisfactory. It is now essential to determine and recommend correct remedial action after an accurate diagnosis of the causes of deterioration of the different structures and their building materials.

Before considering any recommendations for protection, conservation, preservation or repair and maintenance, it is a prerequisite to understand the building materials, construction technology, age, durability, design qualities, 
workmanship, and historical associations with persons or events. Without understanding all these aspects, any repair may cause failure and can involve financial liability to rectify the damage. If the structure is understood thoroughly with expertise along with in-depth supervision, a specific and positive solution can be attained for any conservation work. Therefore, the main problems can be classified into two broad categories as follows:
A. Moisture Problems
B. Problems Associated with Building Materials

\section{A. Moisture Problems}

Almost each and every listed structure of the Sonargaon area is affected with severe moisture problems. The causes may be unique for different structures. Here, the direct penetration of rainwater, or the rising dampness and condensation, create the basic reasons for dampness. Therefore, it is important to identify the exact cause of deterioration before recommending an appropriate method for its rectification. Penetrating dampness should be stopped at the point of penetration. Defective pointing, poor construction detail or cracked external rendering and decoration can contribute to the passage of rainwater and is a common contribution of penetrating dampness. Also, where the internal floor level is below the ground level, or where the water table is high, lateral penetration of dampness might occur. 


\section{B. Problems Associated with Building Materials}

Brickwork: The palaces, secular buildings and mosques of Sonargaon are made of brick. The brickwork of these built forms are commonly affected by (a) Water penetration, (b) Crystallization of soluble salts, (c) Fracture, and (d) Cracking, surface defects etc. due to the differential settlement of structures.

The remedial actions should be unique for the varying causes and definite actions need to be specified on the basis of the detection of accurate causes for deterioration. The repairing method of brickwork is critical, as it might disturb the rest of the sound brick. In cases of replacement, the new brick should match, in color, texture and size, the rest of the brickwork. But unless the removal of brick from its original place is absolutely essential, this would not be a wise decision. Rather it is recommended to patch or reinforce the defective brick with colored mortar that has same appearance of the adjacent brickwork. However, if fracture is the reason for structural weakness and responsible for water penetration, then in-depth remedial actions need to be taken.

Wood / Timber: In Sonargaon, timber has been used extensively in roofs (rafter and purlin), window framings, built in structures (hidden/timber lintels across the opening) and decorative pilasters. The common problems associated with the timber include fungal growth, insect attack and salt migration. 
The high moisture content in the timber is a favorable condition for fungal growth and salt migration as well as insect attacks. Therefore the basic emphasis should be on keeping within the safe limits of moisture content within the buildings. Appropriate precautions need to be taken before the implementation of remedial actions. One must consider whether the roof coverings, rain and soil water disposal systems, joints and damp course insertions are properly treated and protected against water penetration. The existing fungal and insect (especially termite) attacks require whole-scale destruction and sterilization by means of smoke-deposited treatments done regularly on annual basis. In case of replacing the old with new timber, the following items can be taken into consideration:

a) Consistency of the new timber with the original timber

b) Grain and quality wise they should be approximately the same.

c) Second-hand materials might be used to match with the age of the old timber.

d) Moisture content should be within the limited range.

Glass: The following principles can be recommended for conservation, repair, maintenance and protection of all types of glass for the buildings of Sonargaon.

a) Minimum intervention: Any unplanned rearrangements, removals, additions or repairs of historic glass are not acceptable. Therefore the 'have as found' concept should be the primary recommendation for conservation with minimum intervention. i.e., do as little as possible to the glass. 
b) Recording glass is always at risk from some threat, therefore requiring full documentation and recording as a precaution even if it is in very good condition or no work needs to be done.

Reversibility of technique: Glass surfaces cannot be completely protected as there is no perfect solution for them. But it is recommended that the best possible measures should be considered for their protection.

Iron: Wrought iron has been used in railings, and in arches with floral and foliage decoration. Some columns of the secular buildings of Panam Nagar are made of cast iron with decorative patterns at their capital. These columns are mainly hollow and circular. There are some problems associated with iron, such as:

a) Structural failure: It has been observed that some decorative parts of the wrought iron in railings and windows are functioning effectively even where there are acute deformations caused by overloading in the past. Here, the addition of plates, doublers or strengtheners can be recommended for the reinforcement of the default members and loads can be reduced by the reduction of span spaces, introduction of intermediate columns and beams or by replacing some dead load. Therefore, whatever the solution, it should not cause any visual change in the context of conservation.

b) Corrosion: Prevention of water penetration and retention is a vital aspect of corrosion prevention. 
c) Dislocation of joints of irons: This problem can be solved by expert welding.

\subsection{Phase Three: Implementation Level}

This phase involves the actual undertaking of conservation work by the proper authority and the realization of the recommendations made through this thesis. The work done in this phase falls beyond the scope of this thesis. However, in general the implementation phase would involve the following tasks:

Technical Resource identification Phase:

- Technical resource consists of professional team of planners, architects, engineers, supervisors, contractors etc. Before the beginning of work on site these groups of professionals have to be selected who will supervise the project.

- Appointment of appropriate skilled labor, craftsmen experienced in this type of work etc.

- Assessment of availability and quality of appropriate building materials and technology for restoration. 


\section{Construction phase:}

- Management of construction is a vital issue. The project needs to be led by an expert project management team, who will formulate work plan, project schedule and efficient distribution of work.

- Regular supervision is necessary to the project. The professional team of technical personnel is responsible for regular supervision of the work.

- Assessment of the accuracy of the reconstructed part with the original form and features is also among the responsibilities of the technical team.

${ }^{1}$ Sherban Cantacuzino, Ronald. "A Policy for Architectural Conservation." Adaptive Reuse: Integrating Traditional Areas into the Modern Urban Fabric. Ed. Margaret Bentley Sevcenko. Cambridge, Massachusetts: MIT Laboratory of Architecture and Planning, 1983.

${ }^{2}$ Sir John Hubert Marshall (1876 - 1958): English director general of the Indian Archaeological Survey (1902-31). (see Appendix for more)

${ }^{3}$ Imamuddin, Abu H., ed. Architectural Conservation Bangladesh. Dhaka, Bangladesh: Asiatic Society of Bangladesh, 1993. 10

${ }^{4}$ Hussain, A. B. M. Sonargaon - Panam: A Survey of Historical Monuments and Sites in Bangladesh. Ed. M. Harunur Rashid and Abdul Momin Chowdhury. Dhaka, Bangladesh: Asiatic Society of Bangladesh, 1997. 186 


\section{Chapter 6: Case Studies}

\section{1: Case Study 1}

\section{Project name}

Reuse of Nineteenth Century Row Houses in Istanbul

\section{Project by}

Professor Dr. Afife Batur of the Faculty of Architecture at Istanbul University, Author Nur Fersan and Atilla Yucel

\section{Project brief}

The project consists of a study of the existing situation of some nineteenth century row-houses in Istanbul, Turkey and recommendations on the conservation and re-use of these structures. The existing situation at this site has similarities with Panam in various aspects. Panam city itself can be considered to be made of row-houses.

Turkey is in a period of rapid change. The acceleration of change in the socioeconomic structure started slowly during the course of the last century, and then increased with its establishment as a Republic, especially in the 1950s. Most of the increase has been in the largest centres, causing cities like Istanbul, 
Ankara and Izmir to become metropolitan areas. Thus, Turkey is becoming an urbanized country. However, urbanization has reached particularly uncontrollable and problematic dimensions in Istanbul. In addition, the lack of any viable housing policy and organization, despite provisions for them in the constitution and laws, makes the picture one of unremitting gloom: immense squatter settlements, a devastated natural environment and a disappearing architectural heritage. As a result of this destruction, appropriate housing is disappearing and the urban landscape is becoming deformed, adding more still to cultural loss. This situation may very well be the immediate future of Panam, if steps are not taken rapidly.

Evaluation of the historical environment has generally been considered a cultural problem or, more specifically, a cultural-inheritance problem. But, the studies made in this project emphasizes that a human-made environment that has evolved through complex processes will always possess dimensions that cannot be regarded merely as cultural. These additional factors have, in recent years, led to the idea that historic preservation should be expanded from simply saving single monuments to conserving entire environments and social units.

This project integrates theoretical studies and practical experience, in such a way that each benefits from the other although every step could be refined along the way. It also takes economic considerations into account when cultural decisions 
are made. Data is collected to take these aspects into consideration on a theoretical level before the choice of site is actually made.

From their study the researchers find that most of these buildings taken under this project are still structurally sound, although they lack sufficient upkeep. Although currently in a state of neglect, they could be renovated at low costs with only minor restoration. The immediate environs were undamaged, and the preservation area itself was physically intact. The row houses were easy to typify and standardize, and appeared economically suitable for group renovation designs and techniques.

In the next step, the areas were surveyed and the results of these surveys were recorded on maps. Photographs and descriptions of each row house were made and inventory cards drawn up. The buildings of each area were catalogued, classified according to their layout, plan, elevation and group characteristics. Measured drawings of typical buildings were made; these were translated into a diagrammatic presentation technique to enable a typological classification.

The final step in the project was to determine the suitability the inhabitants in each area for a reuse project by collecting data on demographic characteristics. Included in the data were family type, standard of living, utilization of the houses and current demands in housing. The attitude of the user toward the house was 
particularly emphasized, since this would directly affect any rehabilitation decision. Attempts were also made to determine to what extent these nineteenth century designs were fulfilling the needs of their twentieth century users. The kinds and directions of any changes envisaged by the inhabitants were also investigated.

To justify the need for conservation, the researchers state that the distribution and position of the row-houses left in the city today can provide data about certain developmental trends in Istanbul during the nineteenth century and give clues to the geography of social groups in the capital. These houses brought about a new house-street relation as a result of their tendency to form units with the streets in which they were located. The topography of Istanbul has made special contributions to these morphological units at certain places and these qualities alone justify their preservation as environmental units.

The most important finding of the study was undoubtedly the need to conserve the vernacular architecture through adaptive re-use, and to impress the importance of this need not only on public authorities but also on the population as a whole.

Source:

Batur, Afife, Nur Fersan and Atilla Yücel. "Reuse of Nineteenth Century Rowhouses in Istanbul." Conservation as Cultural Survival. Ed. Renata Holod. Philadelphia: Aga Khan Award for Architecture, 1980. <http://archnet.org/library/documents/one-document.tcl?document_id=2603> 


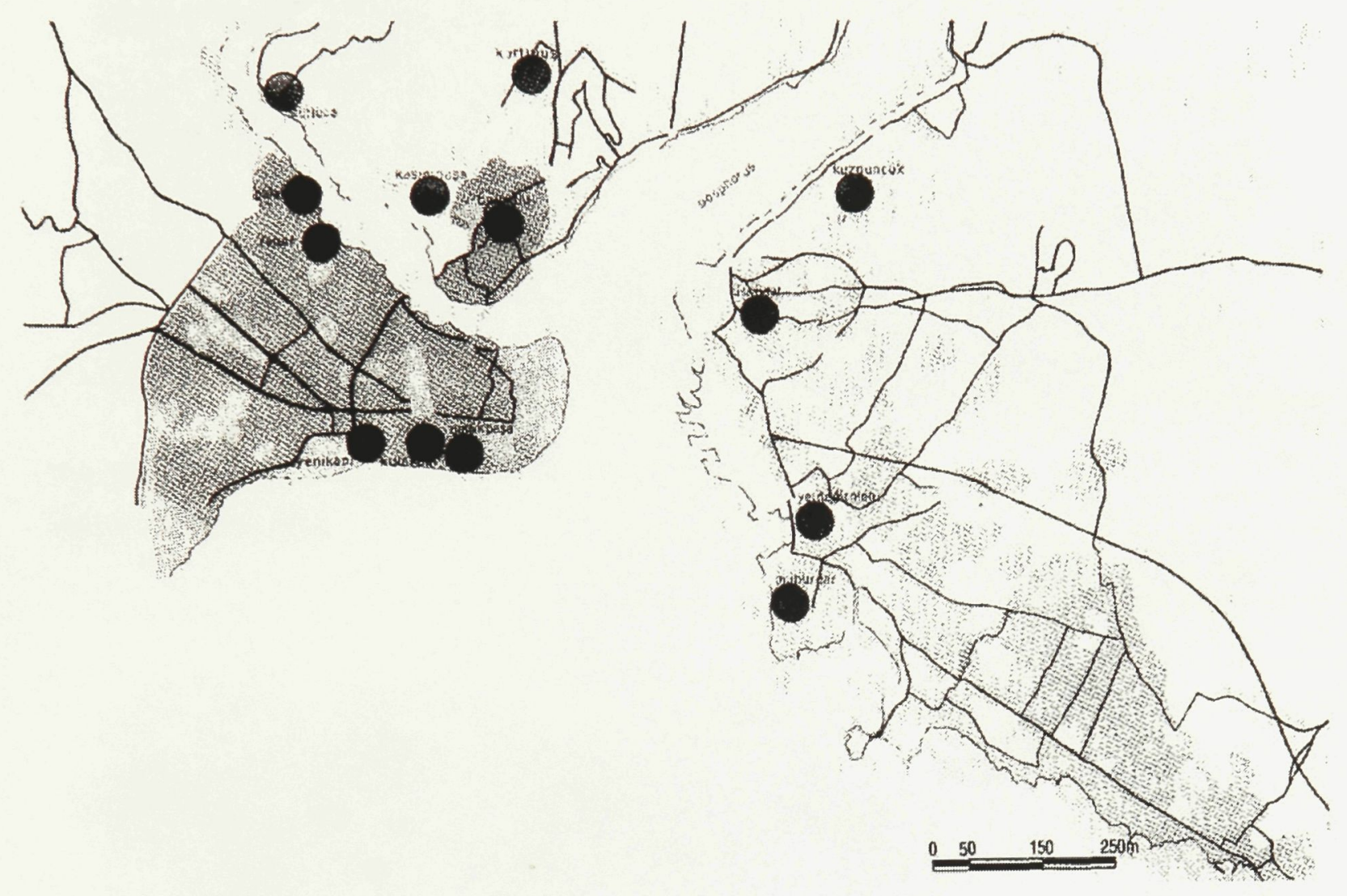

KEY:

Historic centre

Settlement areas

Location of the nineteenth century rowhouses in Istanbul

Photo. A Batur, et al 


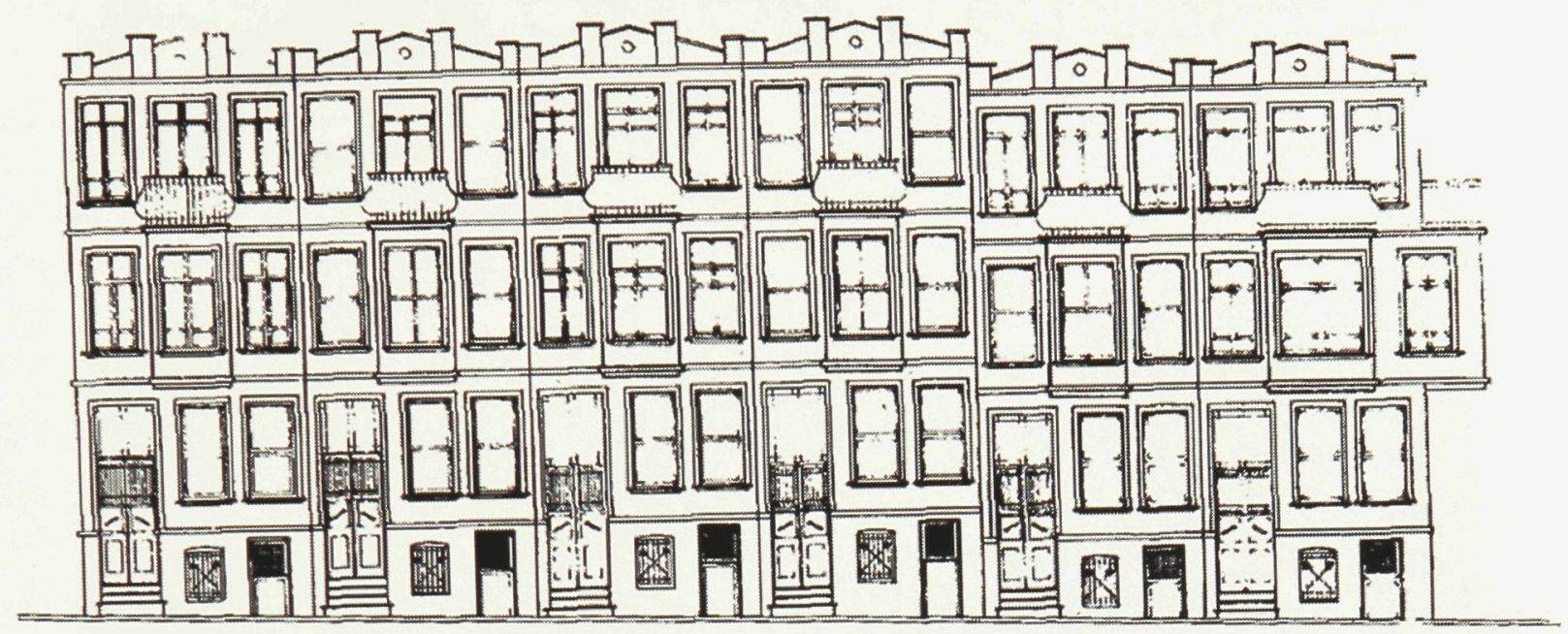

Karakol Street, Mühürdar district rowhouses 25, 27, 29, 31, 33, 35

Photo: A. Batur, et al
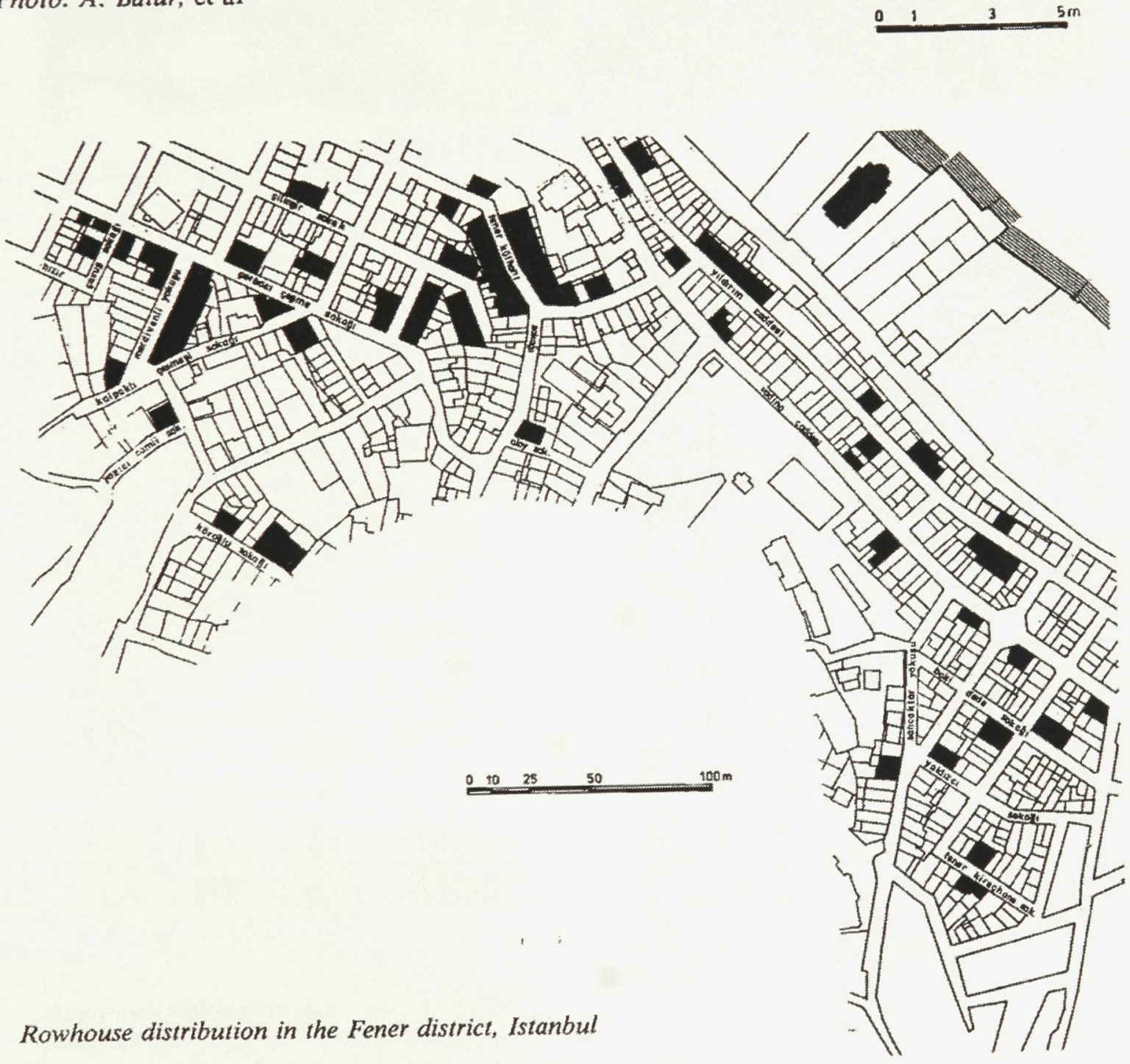

Photo A Batur, et al 


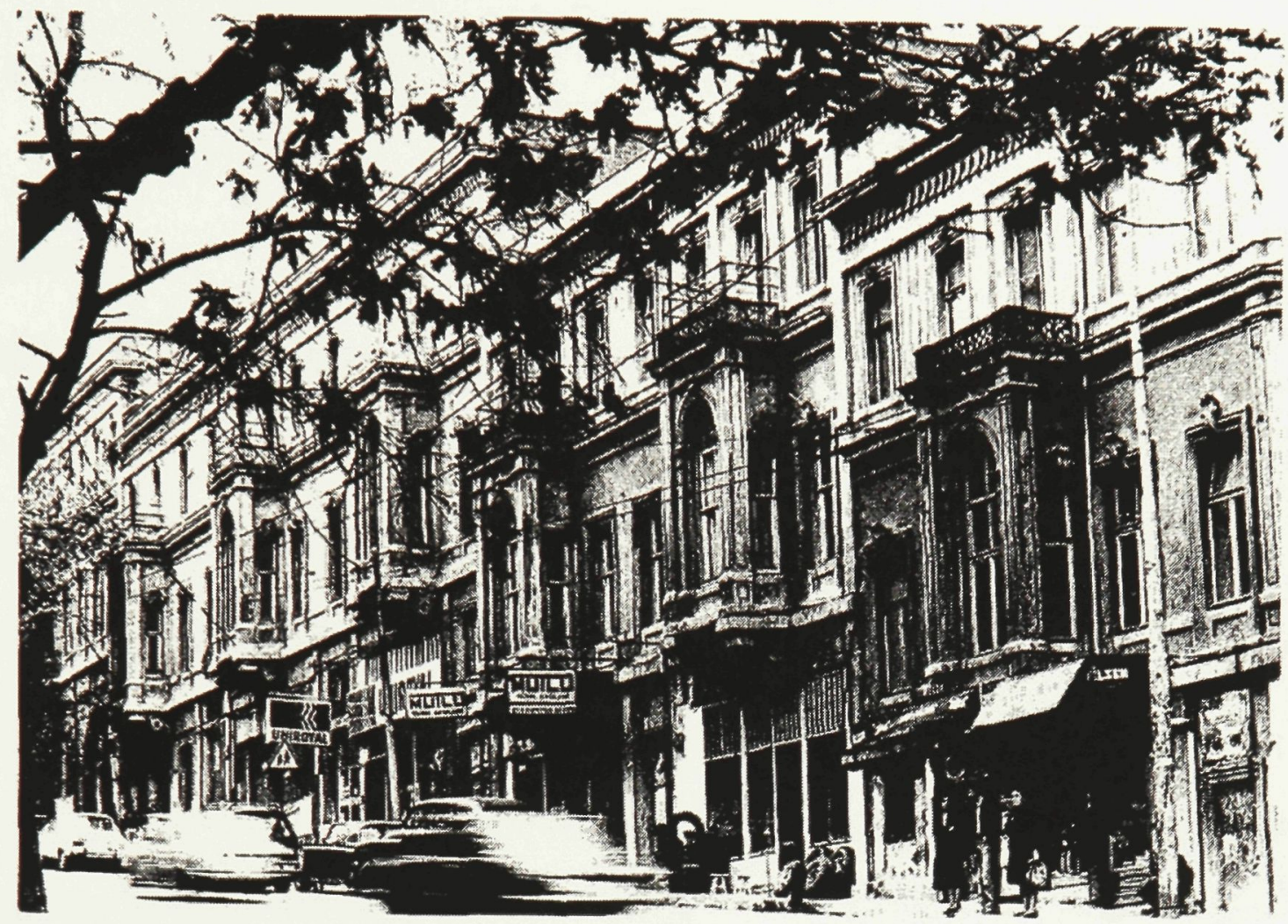

Beșiktaș, Akaretler rowhouses

Photo: A. Batur, et al

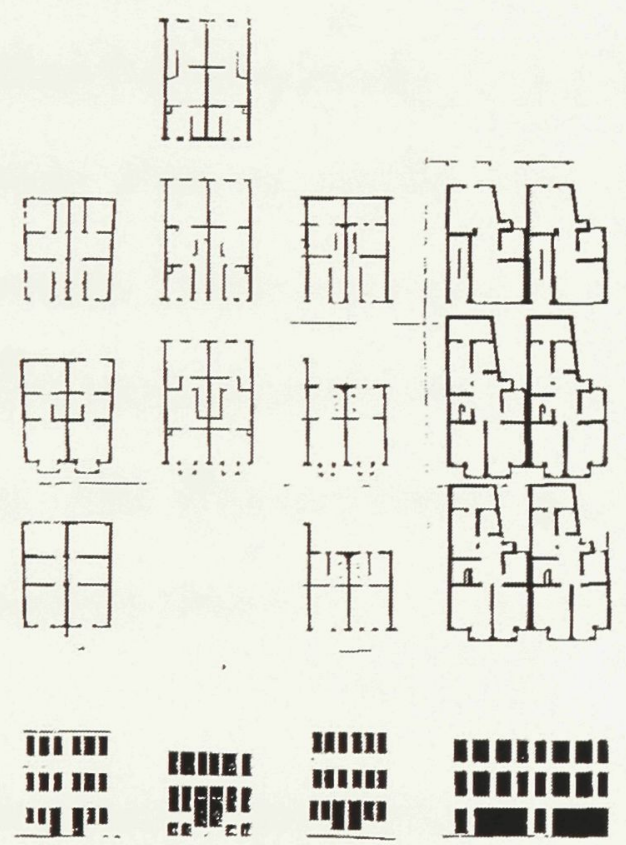

Rowhouse typification scheme: Fener, Kumkapt, Balat districts

Photo A Batur, et al

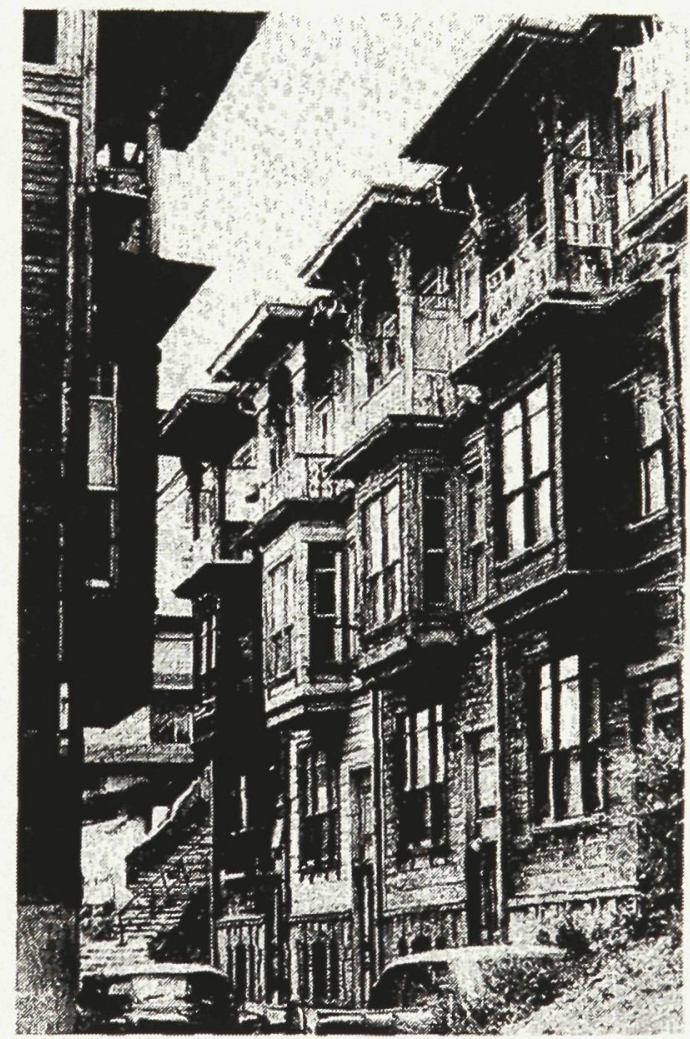

Arnavutköy, Isıanbul: Bakkal Street rowhouses

Photo: A Batur, et al 


\subsection{Case Study 2}

\section{Project name}

Shakhari Patti, a unique old city settlement, Dhaka

\section{Project by}

Abu H. Imamuddin, former lecturer at the Faculty of Architecture, Bangladesh University of Engineering and Technology.

Shamim Ara Hassan, lecturer at the Faculty of Architecture, Bangladesh University of Engineering and Technology.

\section{Project brief}

Shakhari Patti is a locality in old Dhaka. Like many of the localities of old Dhaka, Shakhari Patti is named after the specialized trade and craft of shakha ornaments. These ornaments have a specific socio-cultural value, applied only to married Hindu women, which ensures its regular and widespread use in Hindu areas. This area and Panam Nagar has a number of issues in common, which will become clear from the following paragraphs.

In the urban context of Dhaka, Shakhari Patti is significant in more than one way; culturally, the area houses a specific ethnic group; socio-economically, it provides trade and business for a very special kind of craft; architecturally, it 
demonstrates a development pattern and morphological characteristics typical to that area. Unfortunately, recent observations of Shakhari Patti clearly show an active process of decay and destruction primarily attributed to unplanned growth, random alterations, over-densification and poor maintenance. This project is an objective analysis of Shakhari Patti to identify the area as a case for socioeconomic conservation.

\section{The Site}

According to history, Shakharis are originally inhabitants of Southern India who migrated to this region some 800 years ago and settled in Vikrampur. Subsequently, they received official patronage from Moghul rulers who brought them to Dhaka, allotted free land in the present Shakhari Patti area and waived taxes and duties to encourage the growth of trade. The trade thereby flourished for few a centuries, concentrated within the same area.

Shakhari Patti, in a similar manner as Panam, has grown along a narrow road 10 to 12 feet wide, along a distance of about 600 feet. Rows of densely-built houses, with an average width of only 9 to 12 feet, flank both sides of the street. The street fronts of the ground floors are used for manufacturing and sale of conch shell items while the rear parts of the ground floors and the upper floors are used for the residential accommodation. Typical building features are high plinths, triple arches on the ground floor facades, upper-floor balconies overlooking the 
street, and decorated parapets.

\section{Morphological Development Process}

Shakhari Patti and Panam has another similar characteristic, that is the oblong and linear plots with very narrow frontal widths. In a study for Shakhari Patti the authors describe that the following factors may have been responsible for the development of such plot shapes:

1. Each original allotee may have received a plot with street frontage so that living and trading could be practiced together.

2. Security aspects such as threats of burglary or robbery may have encouraged Shakharis to build closely-packed houses along narrow streets whose only two openings could easily be sealed, shutting off whole areas if necessary. Narrow houses approachable only through narrow dark corridors and unexpected stairways were perhaps deliberately designed to confuse intruders.

\section{House Patterns and Characteristics}

The study of these characteristics in Shakhari Patti influences the study in Panam. Most buildings in Shakhari Patti exhibit the following common features:

1. Houses are divided into three segments: the commercial part facing the street, the residential area in the middle and the service precinct, consisting of the toilets 
and washing areas, in the open courts at the rear.

2. Access to the inner part of the house is through a corridor placed at the side of the house. Corridors are usually divided by a party wall to provide access to the other rooms and upper floors through stairways. Corridors ultimately terminate at service areas at the rear.

3. Upper floors are mostly used for residential purposes. No separate cooking spaces are provided in buildings since cooking is mostly done within family bedrooms.

4. Rooms are arranged within two parallel party walls along a narrow corridor from which two stairways lead to the upper floors.

5. The absence of light-wells in the ground and first floors results in poor lighting and ventilation. Light penetration in these two floors is through the building's front and rear only.

Shakhari Patti now appears as no more than an inner-city slum inhabited by a poor section of the Hindu community. In the past, however, this area was generally occupied by middle-class people along with some exceptionally rich families. Those houses for the rich were bigger and laid out in a quite different 
way from the general typology of today.

\section{Recommendations}

The recommendations for Shakhari Patti made by the researchers have great value for Panam Nagar also. The following paragraphs describe the recommendations made by the authors.

Shakhari Patti offers a unique roadscape through the repetition of common building features and the uniformity in architectural treatment. This gives harmony and continuity in the overall development that is worth conserving. However, this is now being threatened by modern interventions. The settlement, along with its unique socio-cultural heritage, is now in a state of chaos and confusion. There is a general degradation of the whole area which can be attributed to the following possible factors:

First is the ownership issue. The complex nature of ownership patterns has resulted in each house being owned by several families. This has generated a sense of insecurity of ownership and subsequent reluctance on the part of owners to improve the condition of their property.

Secondly, the overall economic hardship caused by the decline in the Shakha business is primarily responsible for the dilapidated condition of the houses. This results in a poor rent structure, leading to a vicious cycle of poverty. 
Therefore, the conservation of Shakhari Patti would imply conserving the craft and community, simply because one is not possible without the other. To effect such conservation, the following recommendations are made:

1. Like other cottage industries, the Shakha business must receive official support and patronage in the form of soft loans, better market facilities and an easier system of procurement of raw materials (an imported item). Shakharis do not presently receive any of such incentives.

2. The infiltration of businesses other than crafts in that area must be discouraged or stopped through restrictive laws. The area should be considered an artisans' village to encourage traditional crafts.

3. The site must be listed as an area for architectural conservation, to prevent demolition of old buildings and to preserve its traditional flavour.

4. Some kind of official ownership rights should be given to the users, on the basis of which loans should be advanced for property improvement. Any plan for development will simply fail without the user's participation in Shakhari Patti.

5. Technical assistance necessary to improve the houses should be made 
available. Better houses will improve the rent structure which will eventually help lower the density.

6. Modern traffic is incompatible with the narrow streets of Shakhari Patti. The streets have a pleasant pedestrian scale and therefore should be converted to a pedestrian lane, so that one can walk safely while watching the Shakharis at work. Conserving the area, by turning it into a more attractive area for residents and tourists alike, should improve business as well as property values while giving people a chance to enjoy the nostalgia of the past.

Source:

Alam, Wahidul, Shamim Ara Hassan and Abu H. Imamuddin. "Shakhari Patti: A Unique Old City Settlement, Dhaka." Architectural and Urban Conservation in the Islamic World. Abu H. Imamuddin and Karen R. Longeteig, eds. Geneva: The Aga Khan Trust for Culture, 1990.

$<$ http://archnet.org/library/documents/one-document.tcl?document_id=3046> 

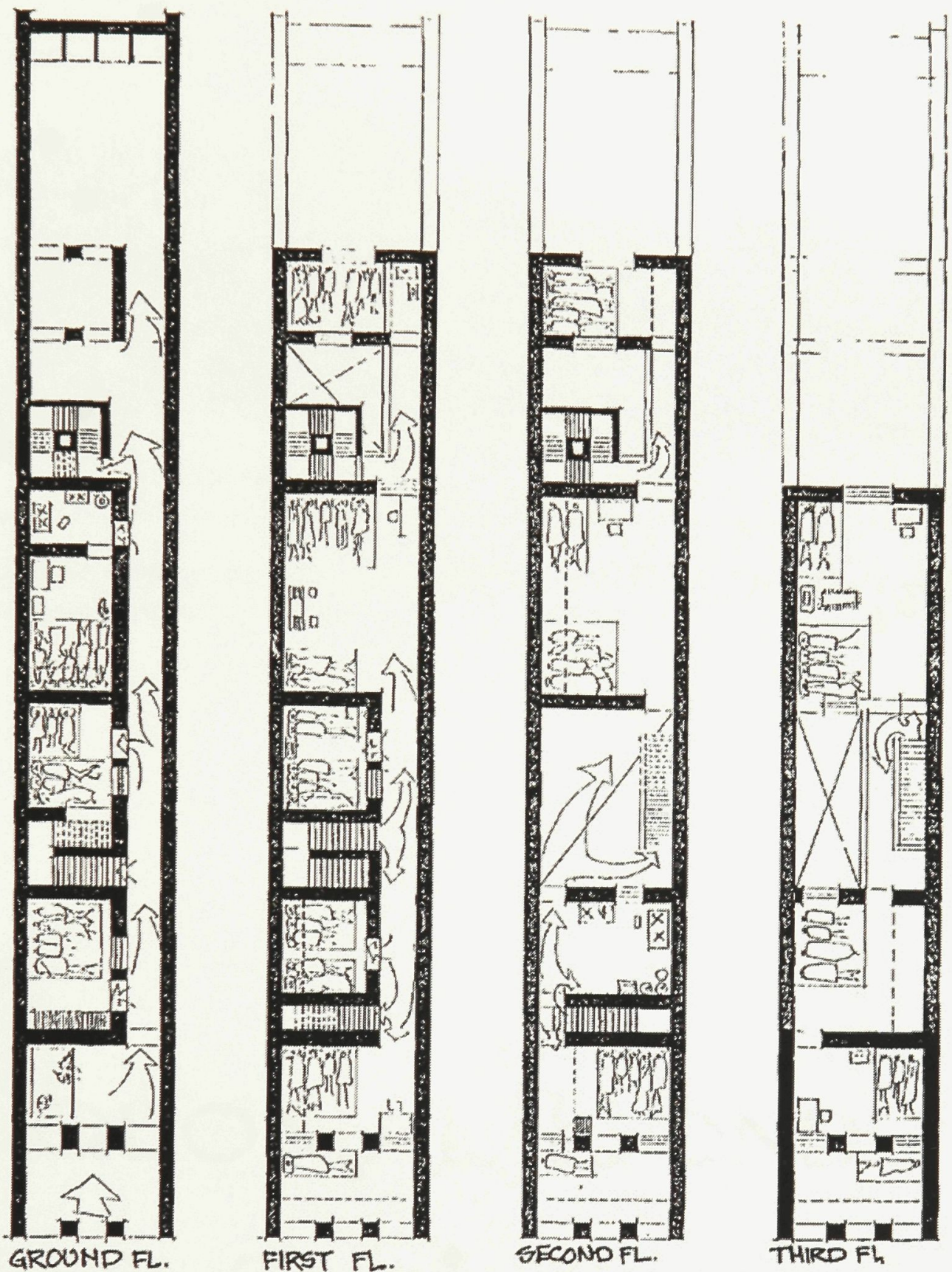

(T) HOUGE NO.32/SHOWING SLEEPING PLAN OF
DIFFERENT FAMILES. 


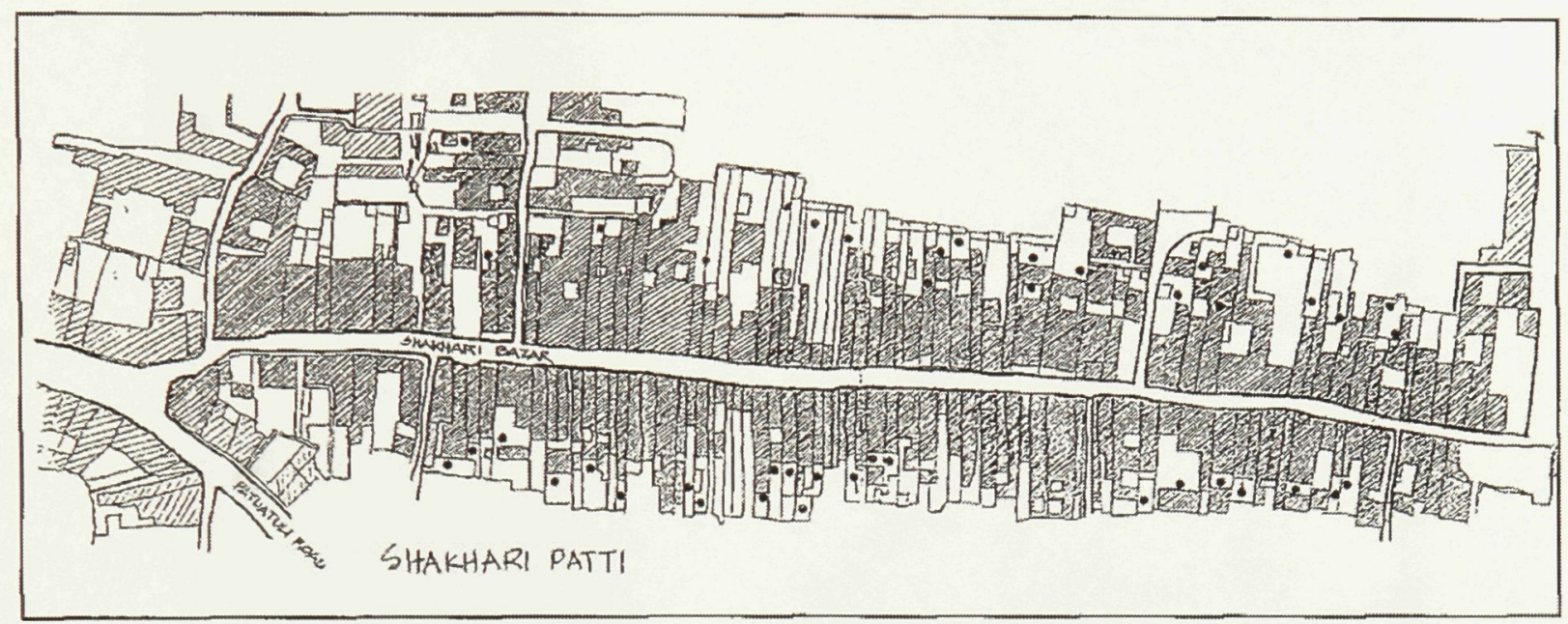

Shakhari Patti, Dhaka Site plan shows the extreme length and narrowness of the plots, strung along one main bazaar road

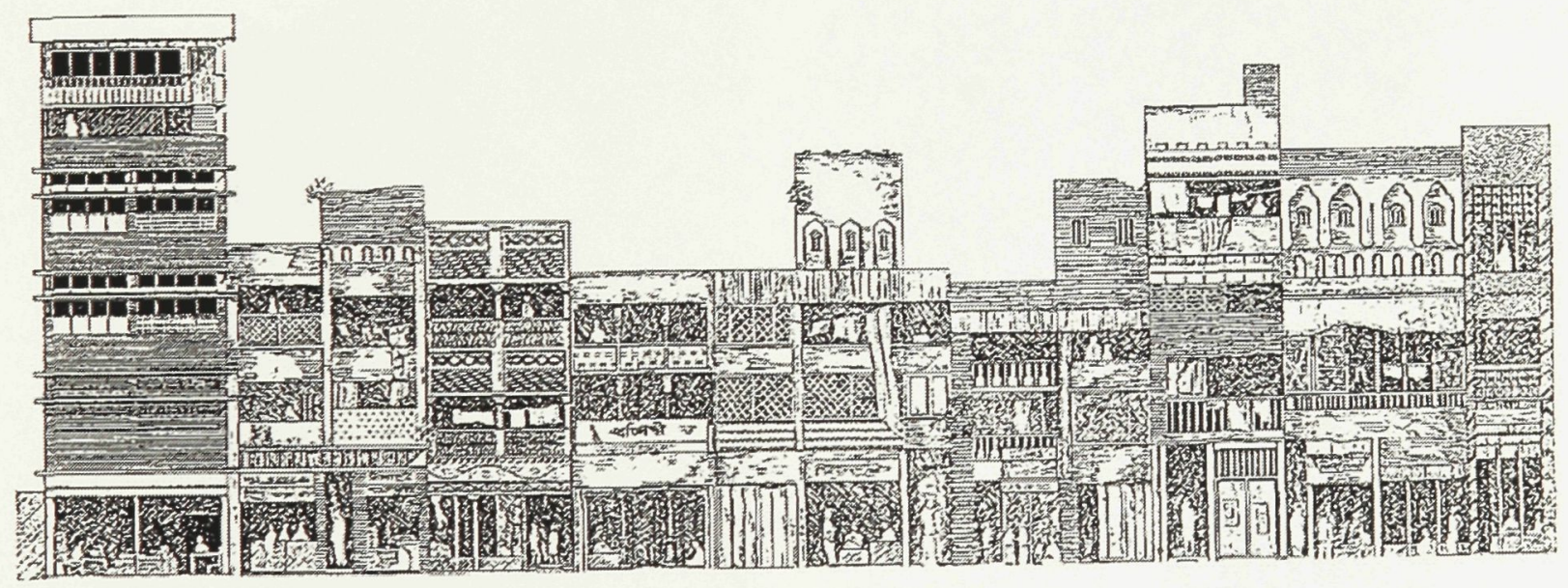

A street elevation shows the bighty-decorated facades on the bazaar side, a view impossible to get naturally due to the extreme narrowness of the street 


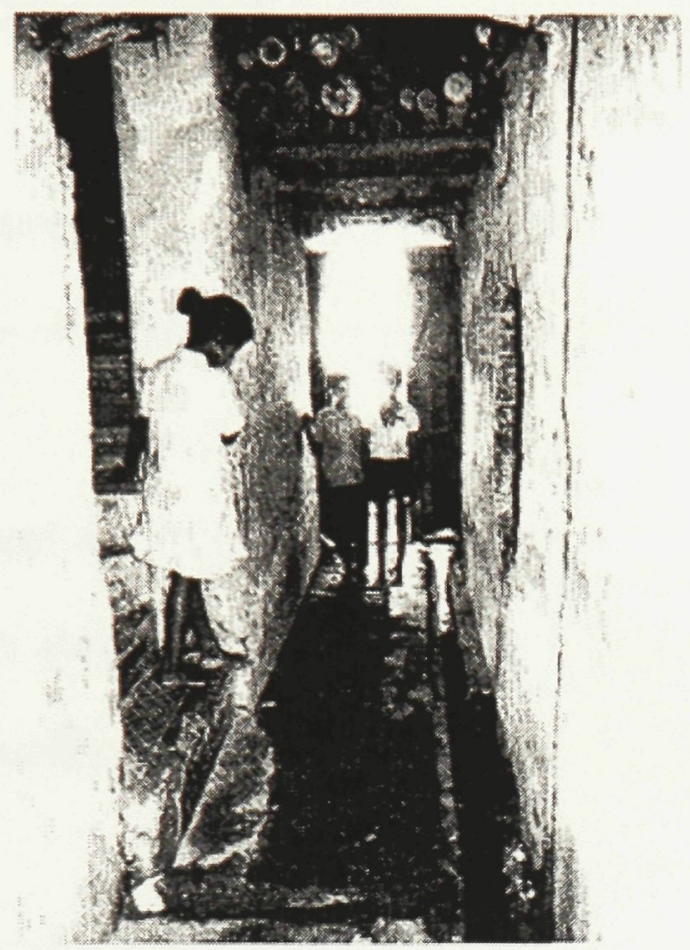

Comidors are narrow but usually provide privale access to all of the many families occupying these sub-divided dwellings

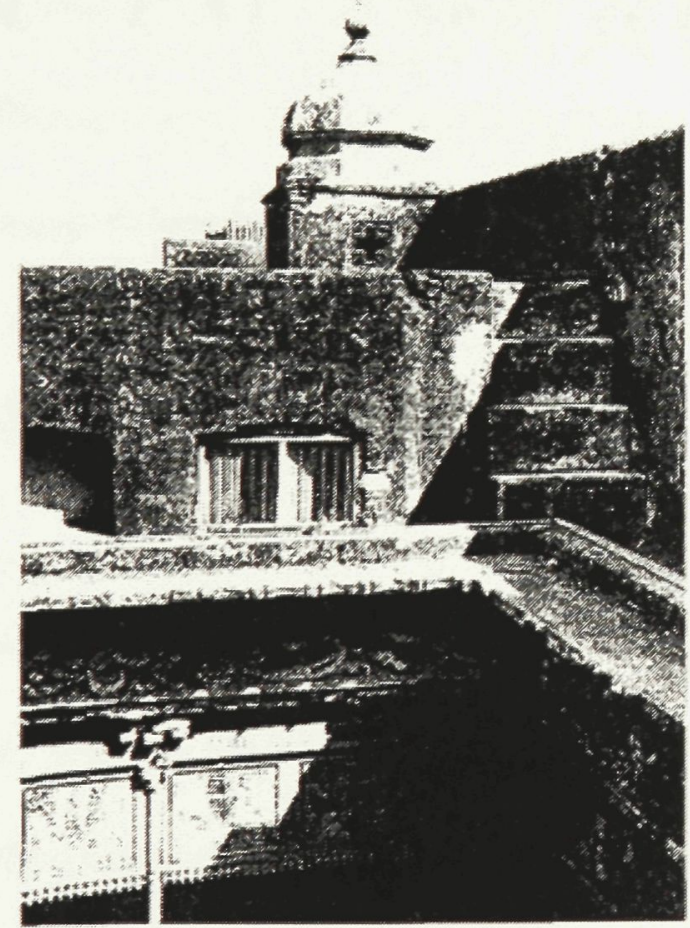

Rooflop view showing the dome of a small mandir or Ilindu family temple on the Nach Mabal bouse The roof top mandir is a typtcal feature of the Shakbari Patti bouse tbough it may not be as elaborate as this one

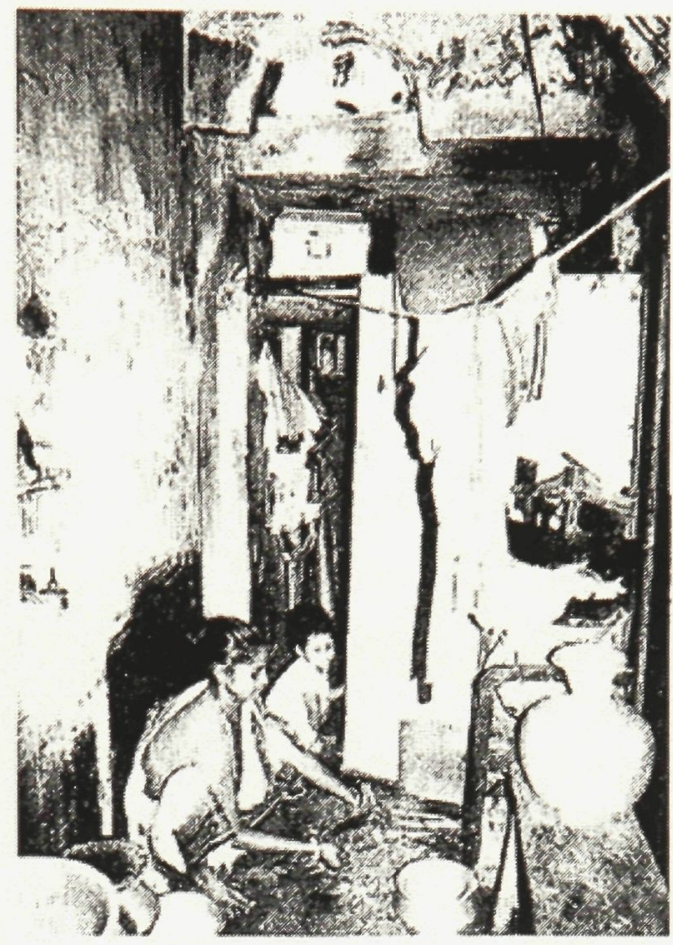

A bouscwife cooking inside Cbipa Bari, a bouse only 5 feet wide

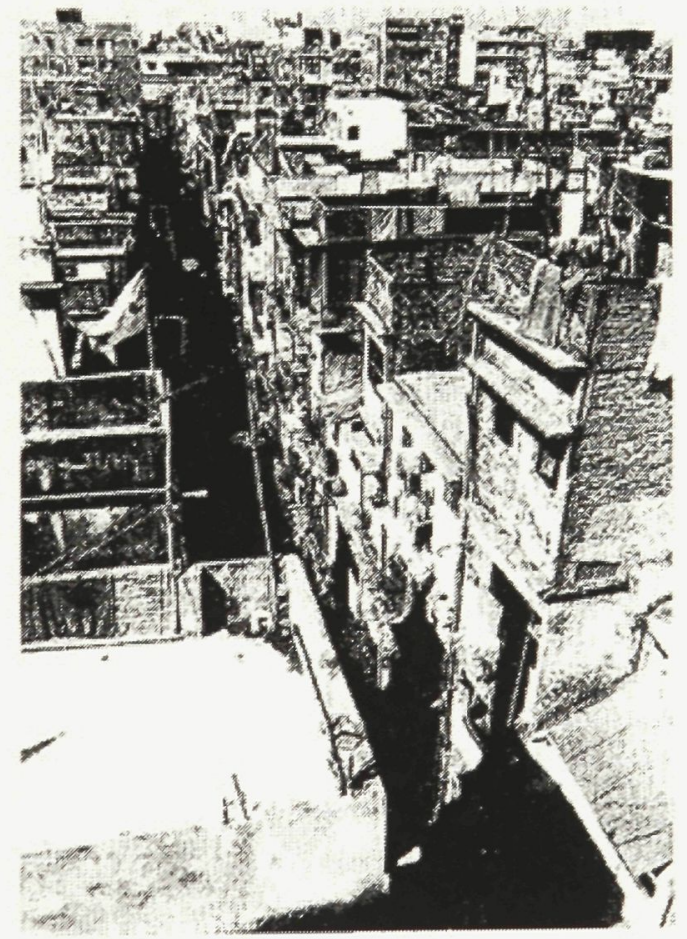

The narrow street senves the densely-built area 


\subsection{Case Study 3}

\section{Project name}

Comprehensive analysis of 5 architectural conservation projects.

\section{Project by}

Shah Alam Zahiruddin, former lecturer at faculty of architecture, Bangladesh University of Engineering and Technology.

\section{Project brief}

The little work on conservation done so far in Bangladesh has been done on government initiative, under the Archeology Department (Ministry of Culture) or the Department of Architecture (Ministry of Works). This writing describes 5 of the most important works undertaken recently. These include Ahsan Manzil, the Star Mosque, the Old High Court Building, the Collectorate Building (Jessore), and the Chummery House.

\section{Ahsan Manzil}

Ahsan Manzil is situated in old Dhaka, by the river Buriganga. Ahsan Manzil, the Palace of the Nawabs of Dhaka, was built in 1872 by Nawab Sir Abdul Ghani. The Palace along with its dome was badly damaged by the tornado of 1888 and was rebuilt as a two-storeyed building, crowned with a dome rising to 58 feet. 
The building faced the river. City life was then oriented towards the waterfront and there was a fine promenade, running along the river bank. Also, Ahsan Manzil was the high point of the old city and it dominated the river front.

During the conservation of this building, books and references on the buildings were consulted, including some exterior and interior photographs taken during the visit of Lord Curzon in 1904. Older people who had visited the palace were consulted; old photographs in personal collections were viewed; and photographs were taken of the still existing damaged structure. From all these, architectural details, sections and elevations were drawn.

After documentation, experiments were carried out with both materials and craftsmanship. Samples with typical details of woodwork were done in the PWD Wood Workshop, and details of mouldings, column capitals and decorative elements were made as samples on site to test and establish workmanship standards.

Ahsan manzil is basically a brick masonry structure. The brick work was extremely damaged by rising moisture. The affected sections were replaced since most of the cast-iron work railings and light posts were missing. Drawings were prepared based on interviews with elderly locals, and the missing parts were restored. 
In addition, the marble floors were damaged in many places. These were easily replaced locally, and sandstone, used in the verandahs, driveways and the steps of the grand staircase, was imported from Joypur in India.

The floor and roof, with a kari-barga system supporting flat burnt clay tiles covered with lime concrete work, was badly damaged in many places. These damages became a major problem of repair.

A portion of the palace compound and the original approach roads have unfortunately been acquired by the Municipal Corporation and the locals. Therefore, these had to be left out of the conservation and restoration scheme. The eastern gate has been repaired and renovated and a brick road paved forming the main entrance to the palace from the city. All unauthorized construction on the Buckland Bund, mostly by shops obstructing the view of the river, has been cleared. 


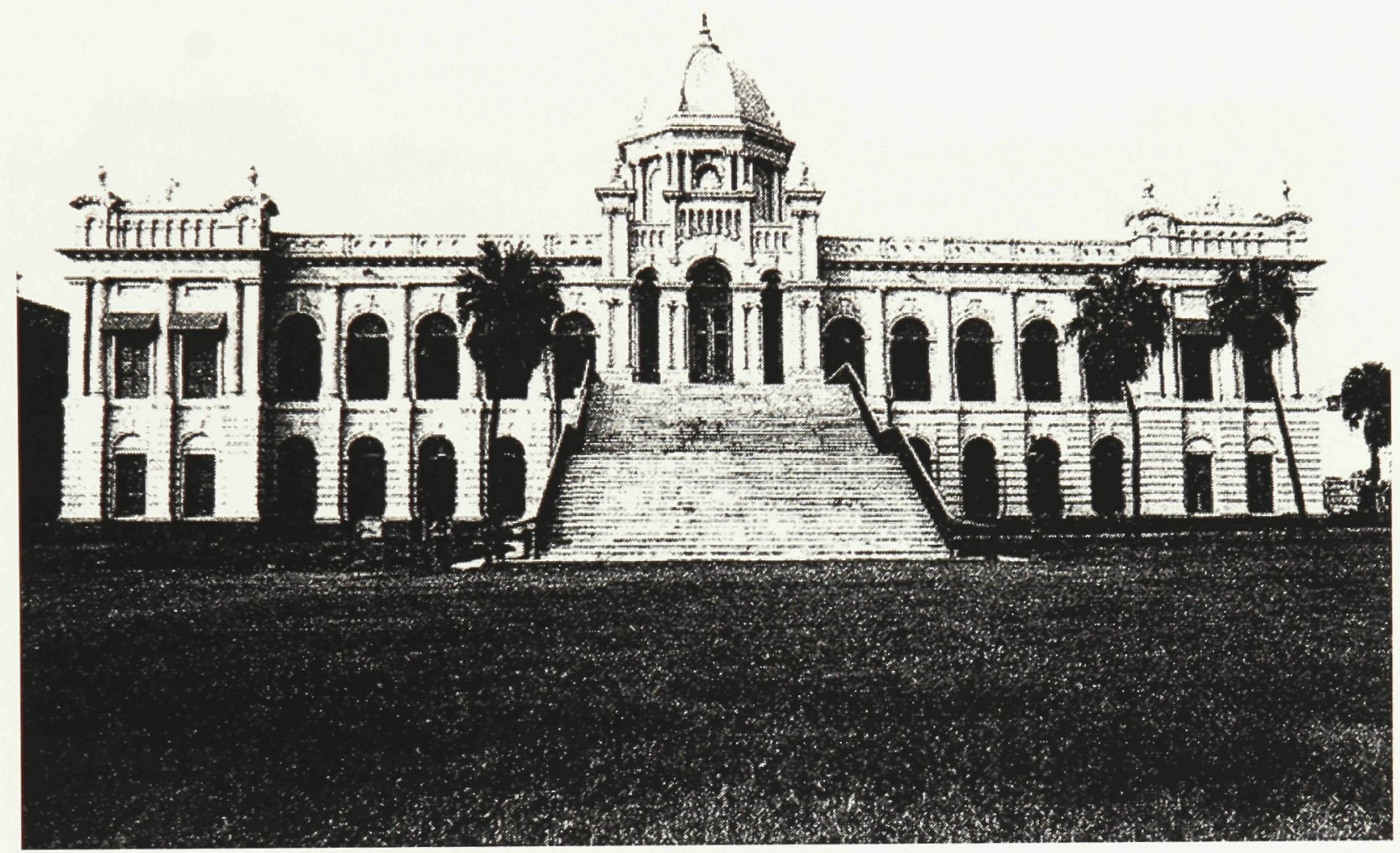

Ahsan Manzil - exterior 


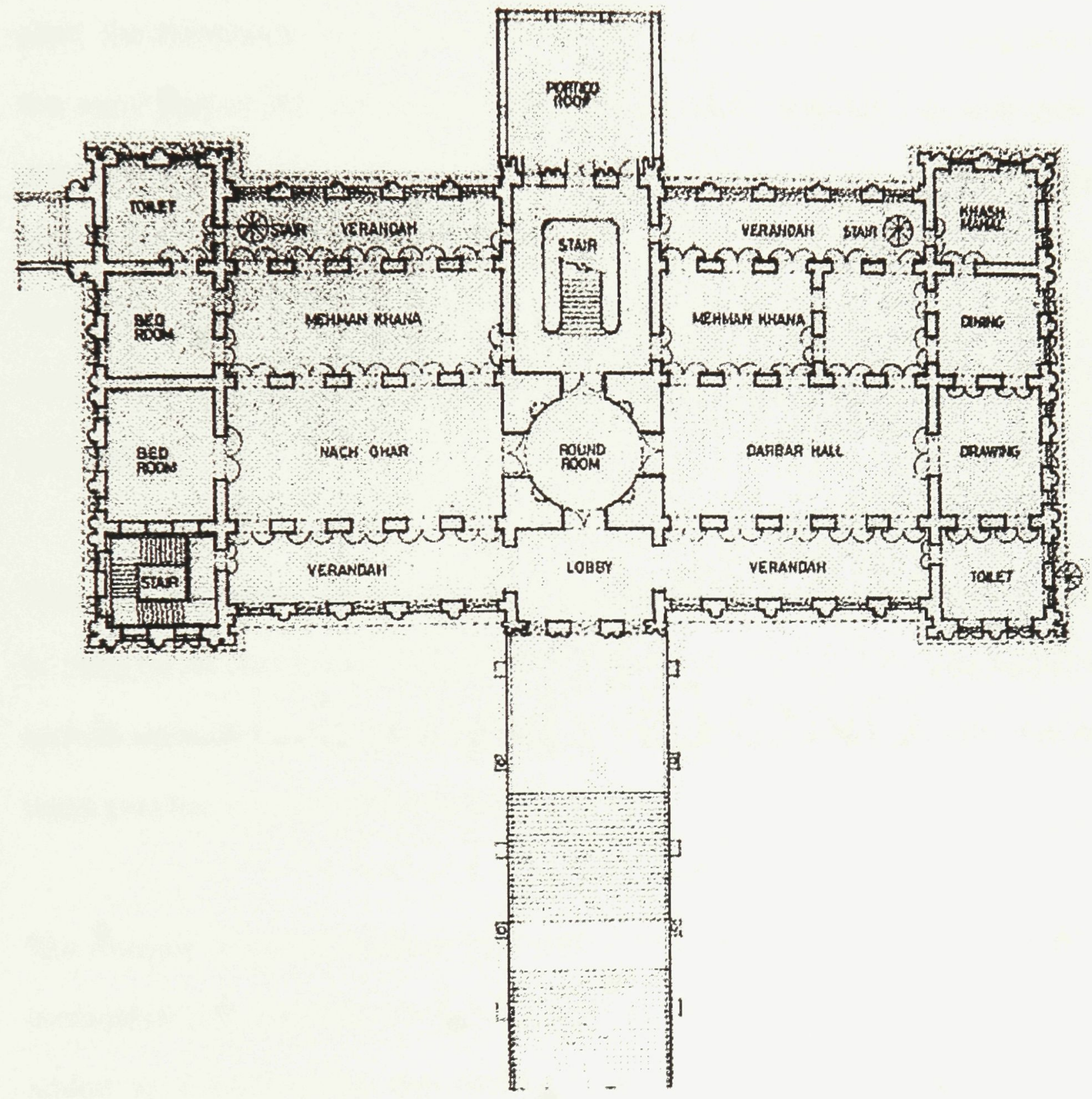

Ahsan Manzil - plan 


\section{Star Mosque}

The Star Mosque is located in Armanitola close to the river. The area is named after the Armenians, the pioneers of the jute trade, who settled in the locality in the early part of the 18th century. The three-domed masonry structure with a dominent central dome 29 feet above the plinth level is clearly in the provincial Mughal style. However, the mosque is famous for its extensive surface decorative work consisting of stars. The stars have been made with a striking mosaic work of broken chinaware pieces, strictly in the local tradition done at a later time.

The new decoration from which the mosque derives its present name was done in 1926 by Ali Jan Bepari, then the Mutawalli of the mosque. He also added an arched verandah to the east, although a verandah in a main mosque was not usual practice in provincial Mughal architecture.

The mosque is part of a living community which has outgrown it. As a result, a corrugated iron sheet structure completely out of character with the mosque was added to accommodate the enlarged community, since the Jumma prayer congregation spilled onto the road every Friday.

A decision for the expansion to accommodate the enlarged congregation was taken in 1984 and the Government Architect's Office took up the responsibility. It 
was apparent that the corrugated iron sheet structure on the north had to be removed and the mosque expanded in that direction.

However, the major issue which confronted this sideways expansion was that the Mughal style of architecture consists of either a single prominent dome or multiple domed roof with a predominant centre dome. The expansion space permitted the construction of not three but only two additional domes on the side, but the existing small western dome would become the central dome. The other possibility was an eastward expansion by expanding the verandah space with another series of colonnades. The impact of the domes would then have been reduced by the addition in front, and the present front of the mosque would have to be covered over by a totally new facade. A decision was therefore taken to expand sideways with two additional domes.

The problem here was that expansion of the Shan was only 32 feet in depth, which could not cater for the larger number of devotees who came to Jumma prayers in such a congested locality. The appropriate choice was to remove apart of the structure on the east and clear the view. Buildings on the east were removed through mutual understanding with the community. A fountain has now been added to the lawn, which was expanded to a depth of 89 feet and covered over with white marble. The drawings were completed in March 1985, and the work completed in December 1987. 


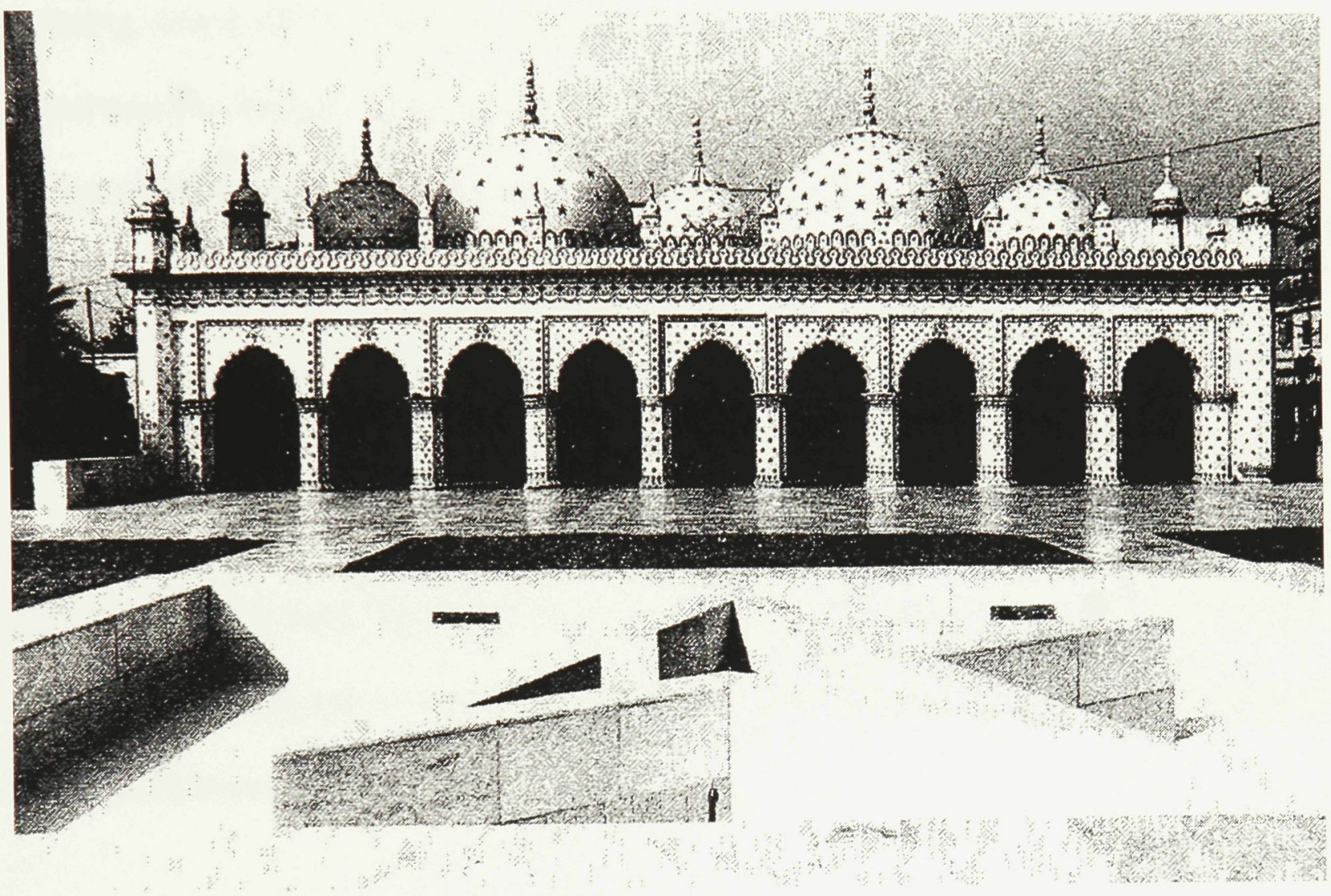

Star mosque - exterior 


\section{Old High Court Building}

Popularly known as the Old High Court Building, this two-storied attractive building was built in 1905 as a residence for the governor of the newly-created provinces of Assam and Bengal. Symmetrical in plan, it was crowned with a dome resting on columns in a circle, and built opposite the Curzon Hall on the road then known as Government House Road. It has been subsequently used as offices, a college, a high court and finally it now houses the Defence Ministry. Built in typical European renaissance style, the architectural elements of the classical period have been very skillfully incorporated into the outer facade. Designed to be very impressive to the outsider, the interior is relatively simple. Cast-iron fencing with intermediate masonry pillars allows passersby a glimpse of the prestigious building.

The building had all kinds of extensions and additions both inside and out, some in concrete and others in corrugated iron sheet and timber partitions. However, the most deplorable were some projecting toilets in the front facade, and also just below the triangular central pediment, there was a big iron verandah roof, to protect the rooms from rain water. The original design made in the European style apparently had no consideration for the local climate.

The outer plaster was falling off in many places and therefore it was time to renovate the plaster work and the building. After the usual process of 
photography and documentation, all additions and changes were dismantled and the work of repair and restoration was initiated.

After climbing the flight of stairs to the first floor on the left, one sees a big ballroom with a wooden floor and a very interesting mezzanine-type gallery, apparently to view the dancing in the hail. The whole ballroom is partitioned into small dark cubicles and even the mezzanine was walled off from the main hall and converted into cubicles. These, however, have all been removed and it now presents a very decent look.

A problem was encountered when the corrugated sheet iron verandah roof over the open terrace on the front was to be removed. There were strong objections that, without covered protection for the doors and windows from the rain and sun, the rooms behind could not be used. Finally, in keeping with the climatic requirements and establishing a relationship with the plan and elevation, a partly covered verandah was added to the front terrace. This is the only addition to the otherwise faithful restoration work, which was completed in 1985. 


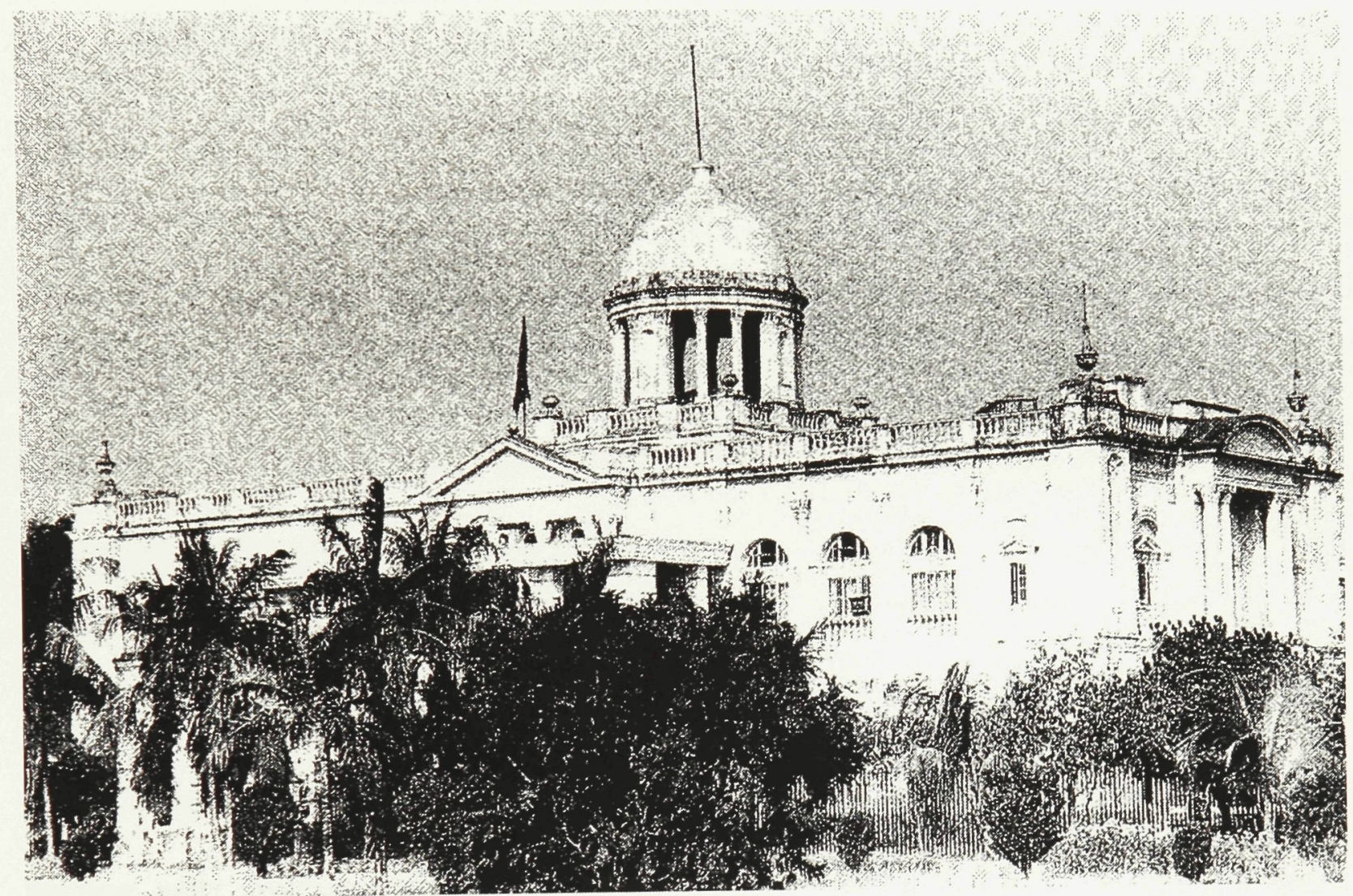

Old high court building - exterior 


\section{Collectorate Building, Jessore}

The Collectorate Building at Jessore was built on a type plan between 1880 and 1920 to house the office of the Revenue Collector. The single-storeyed building with a jack arched roof was supported by 25 -inch thick masonry construction made of burnt clay bricks and lime surki mortar, with the exterior pointed brick work coloured red. On a four foot high plinth, the main office space has a height of 19 feet with a 12 foot high verandah enveloping it. This verandah is a typical response to the local climatic conditions, which was lacking in of the Old High Court Building. The extra height of the rooms made the temperature comfortable even without air conditioners or electric fans.

The architecture here is a hybrid of local and European styles, with distinct Greco-Roman visual features. Verandah openings are typical colonial segmental arches with distinct and prominent keystones at the centre. The ground floor, done in sandstone is ventilated beneath the plinth to avoid dampness. The building also has three porticos on the front facade.

To provide for the need of increased office space while keeping the building's original character, a vertical expansion proposal to convert the Jessore Collectorate into a double-storied building was prepared. To make up the difference in levels between the verandah and the main room, a second reinforced concrete floor was cast over it. The space gained is thus used as 
storage. The facade is treated with three arches for this extra height in place of a single arch below. The verandah parapet and kiosks on the roof of the ground floor were also dismantled and have been used again on the roof of the first floor. This sympathetic expansion can be favorably compared with the Khulna Collectorate Building, which was done without respect for the original character.

\section{Chummery House}

This two-storied British building is an example of vernacular architecture of the late Georgian style. The walls are made of burnt clay brick with mud and lime mortar. The exposed brick work is colored red, as was the style of the day,when it was built around 1911. The sloped and conical-shaped roofs were covered with wood shingles. The roof was subsequently changed to corrugated asbestos sheets. There were also large-scale changes to the exterior during the course of maintenance work of over 70 years by people who showed little thought for architectural character.

To suit the house's present use, large changes have been made internally, but the outside has been faithfully restored in 1985, except for the roofing. The wood shingle roof was found to be too expensive along with being unsuited to the local climate. Asbestos tiles, specially manufactured, diaplay same details as the wood shingles, reducing the cost and increasing the longevity of the roof. The completed landscaping has enhanced the beauty of the surrounding area. 


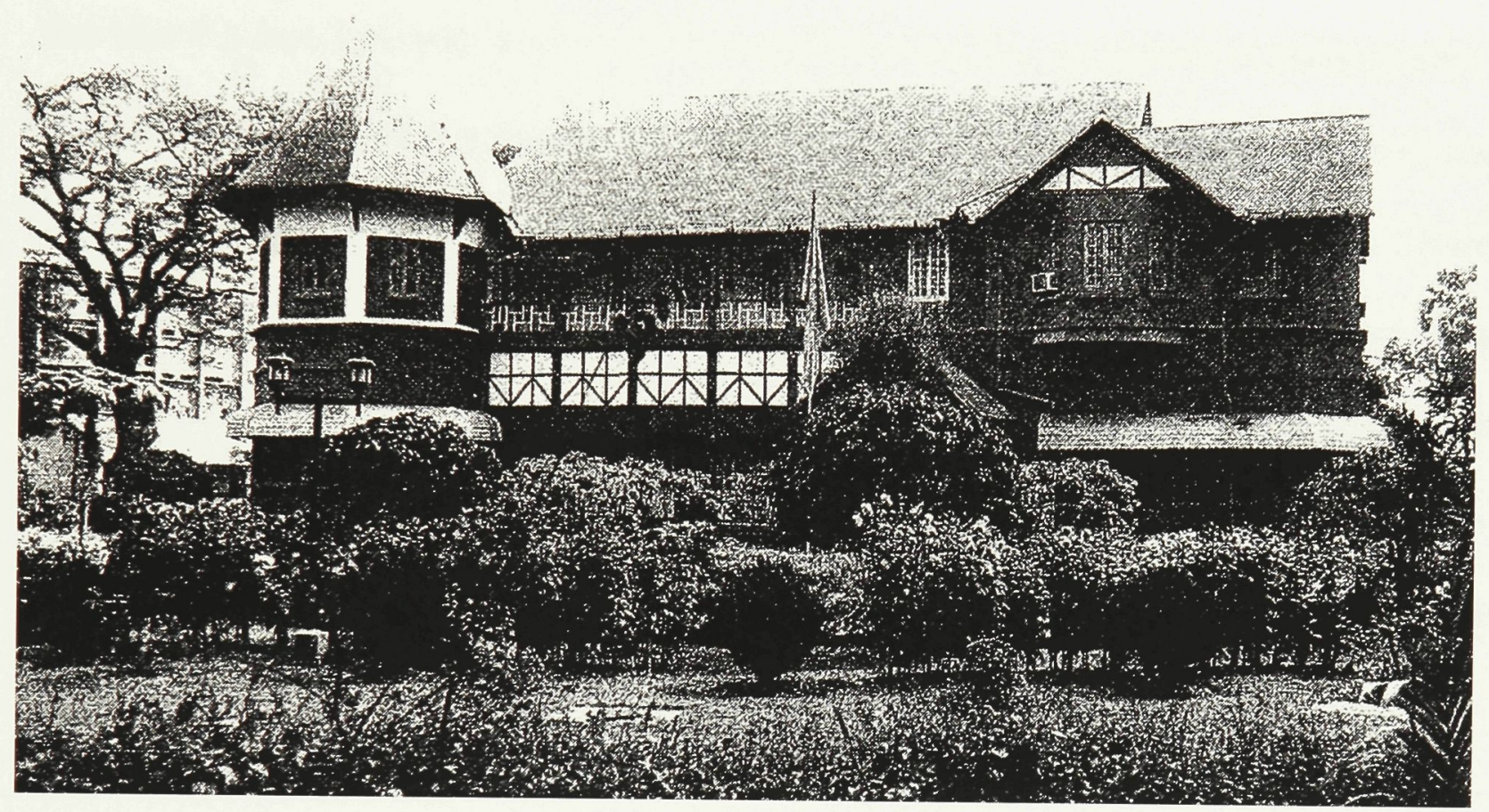

Chummery house - exterior

Source:

Zahiruddin, Shah Alam. "Bangladesh's Experience in Architectural Conservation: Five Projects." Architectural and Urban Conservation in the Islamic World. Abu H. Imamuddin and Karen R. Longeteig, eds. Geneva: The Aga Khan Trust for Culture, 1990. <http://archnet.org/library/documents/onedocument.tcl?document_id=3044> 


\section{Chapter 7: Conclusion}

The Antiquities Act, as amended up to 1976, allows the Archeology Department to declare a monument or site as an Ancient Monument to be preserved under the law if it has been in existence for no less than the preceding hundred years. Generally if and when a building is declared an Ancient Monument (and the total number across the country is only around 200), other than posting a sign board stating that the property is protected under the Antiquities Law, very little work is done to conserve the site or structure. Since most of the structures have been abandoned here, the ravages of nature and vandalism on the mostly masonrybuilt architectural heritage of Bangladesh is thorough and ruthless. Even if the structure is not abandoned and is occupied by rightful descendents of the owners or others, then, perhaps due to a lack of knowledge, the abuse is often so great that it totally defaces the building beyond recognition of its original form and character.

In addition, the efforts in the name of conservation or restoration that have been thus far undertaken were done in an isolated manner. No area as a whole has yet been conserved. As a result, the impact and feeling of the old heritage cannot be perceived in its appropriate environment. In the name of development, particularly in towns and cities, this precious heritage is being demolished rapidly. 
In all the towns, buildings and areas need to be identified as part of cultural heritage and proper documentation needs be done. Merely posting a sign stating that the building is protected under the law is not enough, its history and importance should also be made known to the people of the area to create awareness and pride. The Archeology Department should organize short courses on restoration and conservation to be attended by the officers and staff of the Public Works Department, the municipalities and other organizations responsible for the repair and maintenance of public buildings. This will prevent at least some unintentional defacing and destruction of the architectural heritage.

Lastly, through local bodies constituted for this purpose, permission for development in the areas identified as culturally important should be given only after ensuring that the new development is integrated with, or better yet, is in complete harmony with the surroundings. 


\section{Appendix}

\section{A. Adaptive Re-use}

Old buildings often outlive their original purposes. Adaptive Reuse, or Re-use, is a process that adapts buildings for new uses while retaining their historic features. An old factory may become an apartment building. A rundown church may find new life as a restaurant... And a restaurant may become a church.

One famous example of adaptive reuse is the Gallery of Modern Art for the Tate Museum in London. Designed by the Pritzker Prize winning architects Jacques Herzog and Pierre de Meuron, the museum was once a power station.

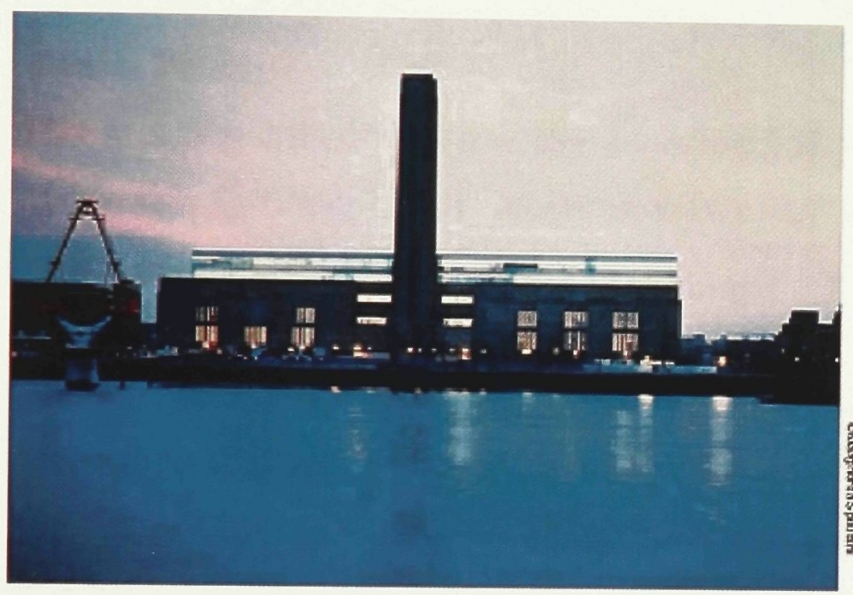

The Tate Modern

by Pritzer Prize Laureates Herzog \& de Meuron

Photo: Courtesy the Pritzker Prize Page

\section{B. Conservation}

1. The act of preserving, guarding, or protecting; the keeping (of a thing) in a safe or entire state; preservation.

2. The act or process of conserving.

3. a. Preservation or restoration from loss, damage, or neglect: manuscripts saved from deterioration under the program of library conservation.

b. The protection, preservation, management, or restoration of wildlife and of natural resources such as forests, soil, and water.

4. The maintenance of a physical quantity, such as energy or mass, during a physical or chemical change. 


\section{Current efforts of conservation at Sonargaon by the government}

Four important structures of Sonargaon the tomb of Ghiyasuddin Azam Shah, the Goaldi mosque, the Sonakanda fort and the Panam Bridge - have been conserved so far by the Department of Archaeology, Government of Bangladesh.

\section{Tomb of Ghiyasuddin Azam Shah}

It appears from a photograph published by James Wise in 1874 A. D. that the sarcophagus had fallen down and the stone stabs lie scattered all around. Thick vegetation had engulfed the structure. But at present, after the conservation work, the sarcophagus is in a fairly stable condition and the area has been cleared of the encroachment of trees.

\section{Goaldi Mosque}

The mosque was brought under protection in 1963. After an initial attempt at conservation in 1964 - 65, the Department of Archaeology took a new approach for extensive restoration, which was implemented in 1975-76.

The monument was in a dilapidated condition. The southeastern wall and the dome were partially missing and heaps of debris occupied the floor of the mosque. The rest of the structure along with the mihrab, cornice, interior surface decoration survived in a decaying condition. Moreover the surviving portion was covered by the heavy growth of vegetation and affected by sulphate action.

At the first attempt at conservation there were gross defects and hence the restored portion was dismantled. Later on all care was taken to restore the mosque to its original form and features. In this phase of implementation the bricks of the unaffected areas were preserved, but the damaged and decayed bricks were taken out and replaced by new ones of same size, color and thickness. The debris accumulated within the prayer chamber was removed and the damaged floor was traced and re-laid after careful study. The terracotta ornamentation of the walls as well as the entire form and features of the mosque were restored. The doorways were provided with iron grills for the protection against undesirable encroachment. 


\section{Sonakanda Fort}

This Mughal Fort was brought under the protection of the Department of Archaeology and it took measures for renovation and conservation. The Fort is now in a fairly good state of conservation. In the renovation work adequate measures were taken to retain its original character.

\section{Panam Bridge}

The three-arched bridge spans a canal (Pankhiraj Khal) between Aminpur and Dulalpur villages. The bridge was heavily covered with trees and bushes which caused deep fissures in the masonry. Bricks were missing or were dislodged from large areas and some portions were badly affected by sulphate action. Very little of the original parapet and wing walls had survived.

The bridge was protected in 1977 and major conservation work was carried out in the following two years. The conservation work comprised of thorough eradication of wild vegetation, rebuilding the missing patches of masonry, specially the missing parapet wall, grouting of the fissures by liquid cement and replacement of old dead plasters with new plasters of lime-surkhi. Attempts were made to bring the original character of the structure. At present the bridge is in a fairly good state of preservation.

\section{Ibn Batuta (1304-1377)}

Ibn Batuta was a moroccan traveller who visited Bengal during the reign of Sultan fakhruddin mubarak shah (1338-1349) and left an account of his visit in his Rehla. He started on his travels in $1325 \mathrm{AD}$ and during the next eight years explored northern Africa, Arabia, Persia, the Levant (the eastern part of the Mediterranean) and Constantinople before he reached Delhi in 1334 AD. Sultan muhammad bin tughlaq appointed him qazi of Delhi. He held this office for about eight years. Then the sultan sent him as an ambassador to China (1342). Shipwrecked on the way, he came to Bengal through the Maldives (1342), Sri Lanka (1345) and southern India. The purpose of his visit to Bengal was to meet Hazrat shah jalal $(R)$ of Sylhet.

The first town of Bengal that Ibn Batuta entered in 1346 was Sudkawan (Chittagong). Then he went to Kamaru (kamarupa) to meet Shah Jalal (R). After a three-day halt in the hospice of the saint he went towards the town of Habank (Habiganj) on the bank of the Nahr ul-azraq (the blue river, ie, Surma). He sailed on this river for fifteen days and reached the town of Sunarkawan 
(sonargaon) where he boarded a Chinese junk bound for Java. His travels in Bangladesh seem to cover a period of less than two months (July-August 1346).

The narratives of Ibn Batuta cover various aspects of life in Bengal. He provides a geographical account of some important places he visited, such as Sudkawan, 'a vast city on the coast of the great sea', Habank 'one of the most glorious and beautiful cities', Sunarkawan, 'a very inaccessible city'. He has given accounts of some rivers he traversed, such as the Ganga (Padma), Jun (Jumna) and Nahr ul-azraq (Surma). The traveller was enamoured of the picturesque landscape, the greenery and beautiful fields, water-wheels, gardens and villages on both banks of the Surma, and comments that passing through villages and orchards was like going through a mart.

Ibn-Batuta provides some information on the political history beginning from the time of Sultan Nasiruddin Mahmud till the assumption of sovereignty by Fakhruddin Mubarak Shah and alauddin ali shah. His narratives include information on the life of Shaikh Shah Jalal $(R)$, influence of sufi saints on both Muslims and non-Muslims, existence of slavery in Bengal, practice of magic and witchcraft by the people of Kamarupa, abundance of food grains and cheap prices of commodities of daily use. He refers to the brisk internal and external trade of this region. $\mathrm{He}$ noticed marketplaces on the banks of the rivers and innumerable boats carrying men and merchandise. He has mentioned the practice of beating drums from every boat on the river as a signal for identifying inland merchant boats and for detecting stranger boats as a safeguard against piracy. He also mentions the sea-borne trade-links of Sonargaon with China, Java and Maldives. In view of the abundance of the necessaries of life and its soothing scenery on one hand, and the wet atmosphere and oppressive vapour bath on the other, the traveller justifies the attitude of foreigners who call Bangladesh a dozakh-i-pur az n'imat, which means an inferno full of gifts.

\section{E. Fitch, Ralph (d. 1611)}

Ralph Fitch, traveler and trader, was the son of a merchant of London. With the object of traveling in the East he came to India in 1583 in a ship called 'the Tiger' with a letter from Elizabeth I (1558-1603), the then Queen of England. Subject matter of the letter was concerning a request for safety of Englishmen's trade and travel. He was arrested in the Iranian port of Hormuz and was taken to Goa under portuguese custody. He was released on bail in 1584 for 2000 duket 
paid by two Christian Fathers. He Left Goa and reached Akbar's capital Fatehpur Sikri via Burhanpur and stayed there up to 1585 . He decided to visit Bengal being advised by his friend Newbury.

Fitch left Agra in 1585, made his journey across the rivers Jamuna and Ganga, passed the cities of Prayag (Allahabad), Benaras and Patna on the way and reached tanda in February 1586 with 180 boats loaded with commodities. From Tanda he went to Kochbehar. From there he proceeded to hughli or 'Porto Piqueno'. From Hughli he came to isa khan's capital sonargaon via satgaon, Bakerganj and Sripur. He went to Chittagong or 'Porto Grande' from Sonargaon. Then he left for Pegu (Myanmar) via Sandwip. He reached Malacca in 1588, and on his way back, he came to Bengal again. He stayed here from November 1588 to February 1589 due to nonavailability of ship. Then he returned to Goa by way of South India. From there he proceeded through Hormuz, Basra, Baghdad, Aleppo, and Tripoli to reach London in 1591.

Ralph Fitch wrote his travel accounts while staying in London. Subsequently this account proved very helpful to the English east india company. In his accounts he gave information about such towns and ports as Tanda, Hughli, Satgaon, Chittagong, Bakerganj, Sripur, Sonargaon as well as the Sundarbans and the course of the Ganga. Ralph Fitch died in 1611.

\section{F. Fei Hsin}

Fei Hsin was one of the three officials who accompanied Admiral (Eunuch) Zheng-He during his voyages to the Indian Ocean in the early medival period. His description of the court of Bangla (Bengal) is an important source to reconstruct the history of medieval Bengal.

Born in 1388 in a family of humble scholars in the Kunshan district of Suzhou prefecture of China, Fei Hsin joined military service at the age of 13 and was chosen to accompany Zheng He's third voyage $(1409-11)$ in a military capacity at the age of 21 . He also accompanied three other voyages, namely, that of Yang Min (1411 - 14) and the fifth (1417 - 19) and seventh voyages (1431 - 33) of Zheng-He.

On his return home in 1433 he wrote a book in 1436 containing notices on various countries and experiences in the Pacific and Indian (called Western by the Chinese) Oceans. The title of his work was Xingocha Shenglan (The Overall Survey of the Star Raft); the 'Star Raft' being the ship 
that carried the imperial ambassador. It is not known when the book was first printed; its earliest version is known to have been published in 1544.

Fei Hsin's travelogue is about half the length of Ma Huan's, but within that limit he provides notices on forty-five places as compared with twenty-one countries described by ma huan. While 19 places are common to both writers, Fei Hsin gives accounts of twenty-six places which are absent in Ma Huan's travelogue; on the other hand, Ma Huan describes two countries which find no place in Fei Hsin. Fei Hsin is the first of the medieval writers to provide information, albeit at second-hand, of La'sa (probably at Muscat or near Bir Ali, 18.19E) in Arabia, and Mogadishu, Brava and Giumbo in East Africa.

Although much shorter, his book complements Ma Huan's on many points. Fei Hsin adds that in Sri Lanka a memorial stone was set up; king Alagakkonara was defeated and captured and the Chinese mission to Bangla included soldiers, received a ceremonial welcome at the customstation of Chittagong and was lavishly entertained by the very generous Sultan of Bangla in his magnificent court at the prosperous capital of Pandua.

There exist many inconsistencies between the accounts of Fei Hsin and Ma Huan; for example, Fei Hsin reports that Phanrang (Panduranga) is a different country from Champa (central Vietnam), whereas Ma Huan's position is that it formed part of Champa. Again, Fei Hsin says that in Champa ten Chinese months made one year, although Ma Huan gives the number as twelve. In India, Ma Huan notices only one Quilon (Kollam), ie the Little Gelan (Xiao Gelan), whereas Fei Hsin seems to have known both Quilon and Cain Kolan which he names Da Gelan (the Bigger Gelan). As regards Bangla, no other Chinese traveller gives the capital's name as Pandua, and for a student of India China trade Fei Hsin provides excellent data about the exchange trade of China with other countries giving the details of payments by China in terms of silks, porcelain wares, gold and other objects.

Fei Hsin and Ma Huan are complementary to each other for knowledge about South Asia during the fifteenth century. 


\section{G. Ma Huan}

Ma Huan - a Chinese traveler - was one of the four officials who accompanied Zheng He (Cheng Ho) during his seven voyages into the Indian Ocean (called Western Ocean by the Chinese) between AD 1405 and 1433. He was a well known figure both in China and elsewhere. Two of his companions wrote travelogues which are known in English translation as The Overall Survey of the Star Raft (1436) by Fei Xin (fei hsin), and Records of Foreign Countries in the Western Ocean (1434) by Gong Zhen (Kung Chen). The latter work is almost identical with Ma Huan's account. The fourth official, Guo Chongli collaborated with Ma Huan in writing their travelogue The Overall Survey of the Ocean's Shores or The Captivating Views of the Ocean's Shores (1433).

Ma Huan's courtesy title was Zongdao; he was from Guiji, a township of Shaoxing district in Zhejiang, a coastal province. Both Ma and Guo were Muslim. Ma, a common Chinese surname, is also used for Muhammad, but whether Guo is similar to a Muslim surname is not known. Another Chinese Muslim surname 'PU' stands for Abu, Abul, or Abdul.

Zheng $\mathrm{He}$, also a Muslim and generally known as Admiral Zheng He, came from Central Yunnan in South China and had the family name Ma (full name Ma He). Admiral He commanded the huge Chinese fleet that scoured the entire Indian Ocean on seven occasions. Both his grandfather and father, perhaps of Mongol or Arab origin, had performed Hajj. Captured by the Ming army during its campaign against the ruler of Yunnan, he was castrated and assigned to the eunuch service under the third ruler of the Ming dynasty, Yongle. This emperor changed Ma He's surname to Zheng because his (the emperor's) mother also bore the surname Ma, and a commoner was not to have a royal surname.

Zheng earned the confidence of Emperor Yongle, and when the emperor wanted to establish contacts with foreign countries, he selected this trusted aide. Zheng He distinguished himself in many military campaigns. It had also been the custom for the Chinese emperors to entrust all foreign assignments to eunuchs, as they were free from family burdens and other worldly liabilities, and their loyalty was considered to be unquestionable.

Ma Huan does not give any idea about his age, but it is presumed that he was born around 1380 and died after 1451 after his book had been published. He must have received a good education, for his literary expressions bear testimony to his acquaintance with Chinese classics and Buddhist works. He was able to compose poems, although in a simple style. In his youth he 
learned Persian and/or Arabic, perhaps from a scholar and he thus became a proficient interpreter.

In 1413 he accompanied Zheng He, along with the other interpreter Guo Chongli, on the fourth voyage of 1413-15 which took the fleet for the first time to Hormuz. After that, he went on the voyage during 1421-23 and on the last voyage in 1431-33 when he journeyed to Makka with the mission for the first and last time. During these three voayges the Chinese missions came to Bengal and Ma Huan acquired first hand knowledge about the country. Back in 1416, he had prepared the first draft of his work along with a foreword. This work, titled Yingyai Shenglan (The Overall Survey of the Ocean's Shores), was given its final form about 1434-6. His colleague Guo Chongli could print the book only in 1451, as the foreword of that year by the imperial clerk Gu Po testifies.

Of the travelogues by the three officials who went on the voyages Ma Huan's is the most detailed. That is why all later works including the official History of the Ming Dynasty depend heavily on Ma Huan's work for information on foreign countries. His knowledge of Persian (and probably also Arabic), and keen sense of inquiry enriched his descriptions of the countries he visited. As a result, in addition to the topography, travel routes and distances in his account of Bangla (Bangge-la), he gives such minute details as the calendar, textiles and woollen products, varieties of wine, crops, marriages and funerals, language, dress and ornaments, currency, merchandise, silk and silk cocoons, dancers and tiger-fighters, and so on. One suspects that during his stay in Bengal he picked up Bangla as well.

Ma Huan appears to be a simple-minded person who loathed violence; he was aghast at the frequency of judicial killings in Java. In his account one can see a travel-writer who had cultivated a spirit of inquiry for novelty. So, in addition to more important matters like distances, travel routes, products, political condition of a foreign country, etc, he also includes folklore and stories such as that of Moses and the Golden Calf at Calicut, as well as descriptions of unusual objects (for a Chinese), viz, jackfruit, rhinoceros, zebra, giraffe, etc. In general, Ma Huan seems to have formed his judgements fairly and without prejudice.

During a century and a half, spread over the early 14th and mid-15th centuries, there were six travellers who wrote considerable accounts- ibn batuta (1326-49), Wang Dayuan (c 1330-50), Fei Xin (1409-33), Ma Huan, Gong Zhen (1413-33) and nicolo de conti (1420-44), leaving out writers like Abdur Razzaq, Nikitin and others. Of these six, four were Chinese travelers, and on the 
whole, Ma Huan is the best of our Chinese informants. Of the twenty countries described by Ma Huan, Ibn Batuta describes only ten; Fei Xin gives a description of eighteen countries, but his accounts are much shorter, and those of Conti must be considered very poor except in regard to Vijayanagar, a country Ma Huan did not visit. Ma Huan's accounts are superior to those of Ibn Batuta except as regards Sri Lanka, Quilon (Kollam) and the Maldives, better than Fei Xin except as regards Champa and Quilon, and superior to Conti except as regards Quilon. Ma Huan's notes display remarkable richness.

\section{H. Questionnaire Survey}

A questionnaire survey was carried out among the local people of Panam Nagar. The purpose of the questionnaire survey was to know about the history of the area according to the local people, past and present condition of the people, their occupation patterns and socio-economic conditions, and gather information about the original owners of the buildings. Participation of the people is needed to define the scope and prospect for new developments.

The questionnaire was originally written in Bengali. And in most cases the survey had to be conducted verbally, as most of the habitants are illiterate.

\section{The Questionnaire:}

Name:

Age:

Occupation: Monthly Income:

Religion: Sex:

Are you the head of the family: $\quad$ Yes / No Family Member:

Type of occupancy of the building: Monthly rental basis / Lease / Ownership / Others If case of the owner,

What is the building being used for?

What is the future plan regarding the building?

Duration of stay in Panam Nagar:

Where did you live before coming to Panam?

Reason for coming here:

Reason for living in this building: 
Type of the building: $\quad 1$ storied / 2 storied / 3 storied

Status of the structure: safe / unsafe / partially safe

Are you satisfied living in this building?

If you were given a new place to live, would you move out? Yes / No

What do you know about Panam?

What do you know about this building?

Do you think this building should be conserved? Yes / No

\section{The results:}

Some of the vital information gathered through this survey is presented below in the form of charts.

\section{Type of occupancy}
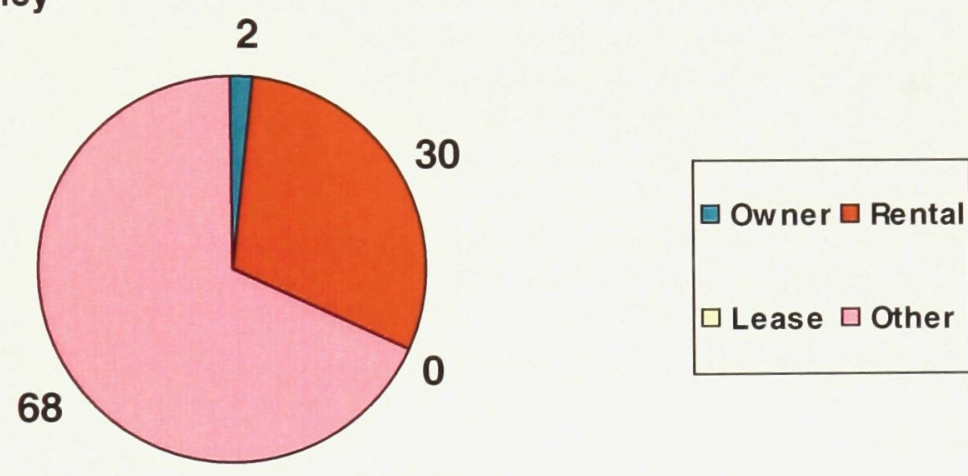

In the question of occupancy, majority answered "other" or hesitated to comment, which indicates that they are living illegally.

\section{Use of building}

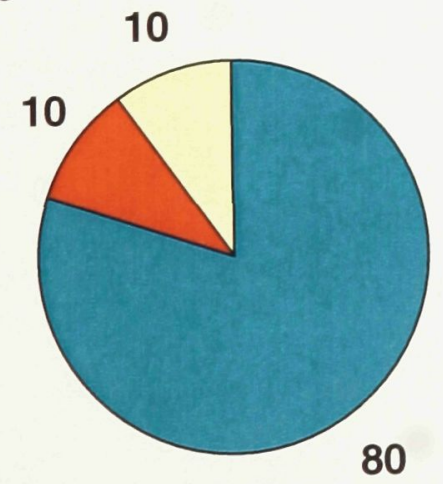

$\square$ Residential

$\square$ Official

$\square$ Other 
Building should be conserved

8

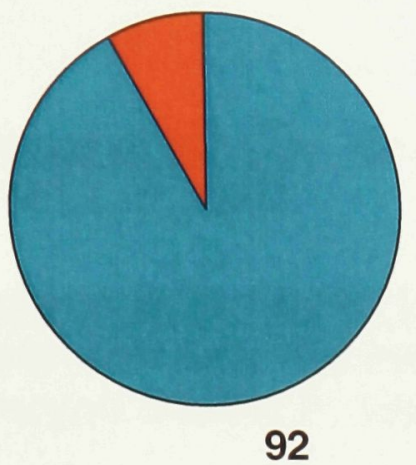

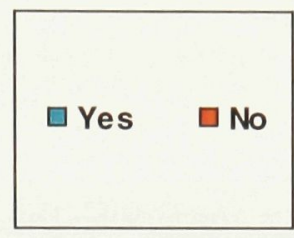




\section{Bibliography}

Lynch, Kevin. The Image of the City. Cambridge, Massachusetts and London, England: The M.I.T. P, 1967.

Haque, UI Saif. Pundranagar to Shere Banglanagar: Architecture in Bangladesh. Ed. Raziul Ahsan and Kazi Khaleed Ashraf. Dhaka, Bangladesh: Chetana Sthapatya Unnoyon Society P, 1997.

Rossi, Aldo. The Architecture of the City. Ed. Peter Eisenman and Kenneth Frampton. Cambridge, Massachusetts and London, England: The M.I.T. P.

Jokilehto, Jukka. A History of Architectural Conservation. Ed. Andrew Oddy. Woburn, MA: Butterworth and Heiremann P, 1999.

Mitchell, J William. The Logic of Architecture: Design, Computation and $\underline{\text { Cognition. }}$ Cambridge, Massachusetts and London, England: The M.I.T. P, 1944.

Hussain, A. B. M. Sonargaon - Panam: A Survey of Historical Monuments and Sites in Bangladesh. Ed. M. Harunur Rashid and Abdul Momin Chowdhury. Dhaka, Bangladesh: Asiatic Society of Bangladesh, 1997.

Imamuddin, Abu H., ed. Architectural Conservation Bangladesh. Dhaka, Bangladesh: Asiatic Society of Bangladesh, 1993.

Haldenby, Eric, and Lorenzo Pignatti. The Design of Antiquity. N.p.

Krautheimer, Richard. Rome-Profile of a City, 312-1308. Princeton, New Jersey: Princeton University P, 1980.

Hossain, Md. Mosharaf. BANGLADESHER NAGAR : Udhvab O Bikash. Ed. A. K. M. Shahnawaz. Dhaka, Bangladesh: Protik Publishers, 2001.

Karim, Md. Razaul. SONARGAONER ITIHAS: Utsa O Upadan. Ed. Dr. Saikat Asghar. Dhaka, Bangladesh: Rahman Group of Industries, 1993.

Shahnawaz, A.K.M. History of Indian Subcontinent - Ancient Period. Dhaka, Bangladesh: Protik Publishers, 1999.

---. History of Indian Subcontinent - Sultanate Period. Dhaka, Bangladesh:

Protik Publishers, 2002. 
---. History of Indian Subcontinent - Mughal Period. Dhaka, Bangladesh: Protik Publishers, 2002.

---. History of South Asia (Since 1526). Dhaka, Bangladeh: Protik Publishers, 2003.

Sevcenko, Margaret Bentley. "Adaptive Reuse and Its Problems: A Discussion." Adaptive Reuse: Integrating Traditional Areas into the Modern Urban Fabric. Ed. Margaret Bentley Sevcenko. Cambridge, Massachusetts: MIT Laboratory of Architecture and Planning, 1983.

Daifuku, Hiroshi. "The Problems of Conservation in Developing Countries and the Role of International Organizations." Adaptive Reuse: Integrating Traditional Areas into the Modern Urban Fabric. Ed. Margaret Bentley Sevcenko. Cambridge, Massachusetts: MIT Laboratory of Architecture and Planning, 1983.

Lewcock, Ronald. "The Technical Aspects of Upgrading Old Areas." Adaptive Reuse: Integrating Traditional Areas into the Modern Urban Fabric. Ed. Margaret Bentley Sevcenko. Cambridge, Massachusetts: MIT Laboratory of Architecture and Planning, 1983.

Sherban Cantacuzino, Ronald. "A Policy for Architectural Conservation." Adaptive Reuse: Integrating Traditional Areas into the Modern Urban Fabric. Ed. Margaret Bentley Sevcenko. Cambridge, Massachusetts: MIT Laboratory of Architecture and Planning, 1983. 